\title{
Chemical and Charge Imbalance Induced by Radionuclide Decay: Effects on Waste Form Structure
}

Fuel Cycle Research \& Development

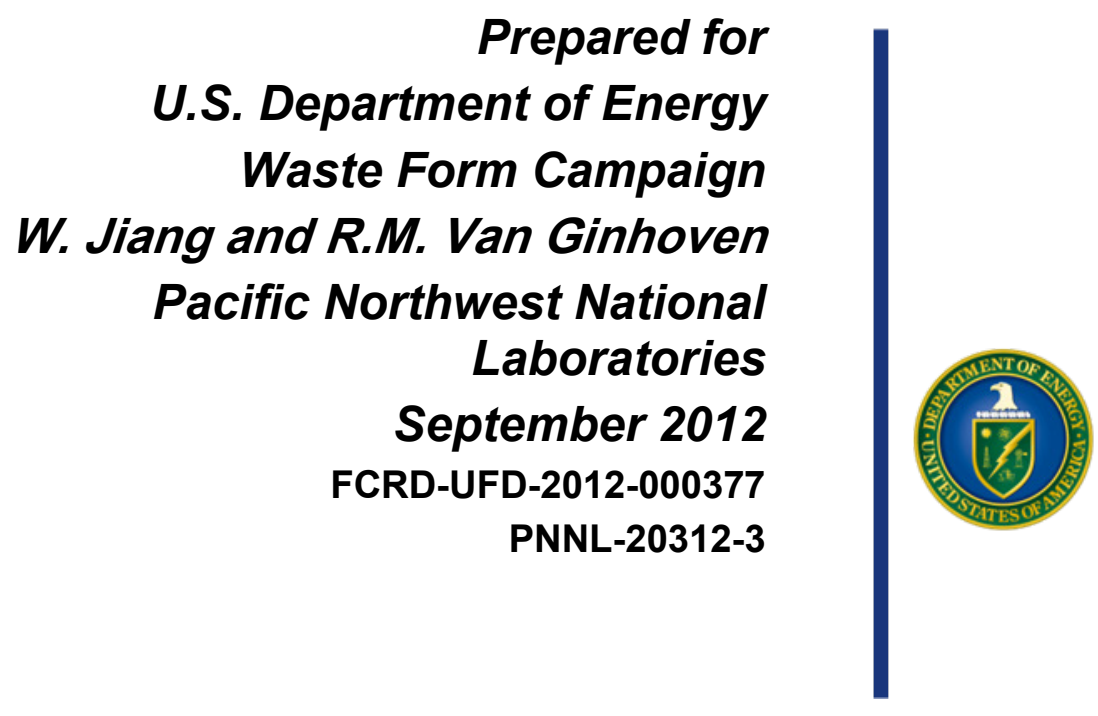




\section{DISCLAIMER}

This information was prepared as an account of work sponsored by an agency of the U.S. Government. Neither the U.S. Government nor any agency thereof, nor any of their employees, makes any warranty, expressed or implied, or assumes any legal liability or responsibility for the accuracy, completeness, or usefulness, of any information, apparatus, product, or process disclosed, or represents that its use would not infringe privately owned rights. References herein to any specific commercial product, process, or service by trade name, trade mark, manufacturer, or otherwise, does not necessarily constitute or imply its endorsement, recommendation, or favoring by the U.S. Government or any agency thereof. The views and opinions of authors expressed herein do not necessarily state or reflect those of the U.S. Government or any agency thereof. 


\section{SUMMARY}

\section{Experimental}

Following our study of model waste form of $\mathrm{SrTiO}_{3}$ for fission product ${ }^{90} \mathrm{Sr}$ reported previously, this technical report focuses on our research progress on the aluminosilicate pollucite waste form, where ${ }^{137} \mathrm{Cs}$ decays to ${ }^{137 \mathrm{~m}} \mathrm{Ba}$ and then ${ }^{137} \mathrm{Ba}$ by emission of a $\beta^{-}$particle and a $\gamma$ photon or directly to ${ }^{137} \mathrm{Ba}$ by emission of a single $\beta^{-}$particle. A natural pollucite mineral from Marin Mineral and three types of sintered samples of undoped $\left(\mathrm{CsAlSi}_{2} \mathrm{O}_{6}\right)$ and Ba-doped $\left(\mathrm{Cs}_{0.9} \mathrm{Ba}_{0.05} \mathrm{AlSi}_{2} \mathrm{O}_{6}\right.$ and $\left.\mathrm{Cs}_{0.9} \mathrm{Ba}_{0.1} \mathrm{AlSi}_{2} \mathrm{O}_{6}\right)$ pollucite from Sandia National Laboratories are used in this study. The Ba-doped samples were implanted with $\mathrm{F}^{+}$(and $\mathrm{O}^{+}$) ions up to an atomic concentration of 5 at. $\%$ at the profile peak. The implanted anions were intended for charge compensation in the charge-imbalanced Ba-doped pollucite $\mathrm{Cs}_{0.9} \mathrm{Ba}_{0.1} \mathrm{AlSi}_{2} \mathrm{O}_{6}$. The implantation was performed at elevated temperatures $(573$ or $673 \mathrm{~K}$ ) and the implanted samples were subsequently annealed in flowing Ar environments at 873, 1073 and $1423 \mathrm{~K}$. The as-sintered, ion-implanted and thermally annealed samples have been analyzed using a variety of experimental methods, including Rutherford backscattering spectrometry (RBS), secondary ion mass spectroscopy (SIMS), x-ray diffraction (XRD), electron probe microanalyzer (EPMA) based energy-dispersive x-ray spectroscopy (EDS) and wavelength-dispersive x-ray spectroscopy (WDS), inductively coupled plasma atomic emission spectroscopy (ICP-AES), x-ray photoemission spectroscopy (XPS), helium ion microscopy (HIM), and transmission microscopy (TEM). This experimental report will focus on the study of $\mathrm{F}^{+}$ion implanted $\mathrm{Cs}_{0.9} \mathrm{Ba}_{0.1} \mathrm{AlSi}_{2} \mathrm{O}_{6}$.

A natural pollucite sample is prepared and is found to be a single crystal with poor quality that is not suitable for ion-channeling study. The as-sintered, surface-polished disks have a major phase of basically cubic pollucite structure without water. Their overall composition is nearly stoichiometric with a crystallite size ranging from $100 \mathrm{~nm}$ to $1 \mu \mathrm{m}$. The doped Ba prefers to aggregate at the boundary of the pollucite grains. There appear other minor phases in the material, including Si and/or Al oxides. Some impurity elements, such as $\mathrm{Na}$ and $\mathrm{Ca}$, are also identified. In general, the implantation band is well predicted by computer simulations based on the SRIM code. Results show that fluorine is mobile in the sintered $\mathrm{Cs}_{0.9} \mathrm{Ba}_{0.1} \mathrm{AlSi}_{2} \mathrm{O}_{6}$ pollucite at elevated temperatures. At $873 \mathrm{~K}$ for 4 hours, $\mathrm{F}$ diffusion is observed. More significant diffusion occurs with loss of $\mathrm{F}$ at $1073 \mathrm{~K}$ for 4 hours. The implanted $\mathrm{F}$ diffuses out and escapes from the samples completely after annealing at $1423 \mathrm{~K}$ for 10 hours. The implantation layer was fully amorphized after high-dose $\mathrm{F}^{+}$ion irradiation at $673 \mathrm{~K}$. Only slight recrystallization is observed after annealing up to $1073 \mathrm{~K}$. Nearly a complete recovery takes place at 1423 $\mathrm{K}$ for 10 hours. Gas bubbles appear in the as-implanted $\mathrm{Cs}_{0.9} \mathrm{Ba}_{0.05} \mathrm{AlSi}_{2} \mathrm{O}_{6}$, but not in the implanted $\mathrm{Cs}_{0.9} \mathrm{Ba}_{0.1} \mathrm{AlSi}_{2} \mathrm{O}_{6}$ even after annealing at $1073 \mathrm{~K}$. The depth profile of $\mathrm{F}$ in the latter sample is rather flat. The results suggest that $\mathrm{F}$ may be trapped by forming chemical bonds with the excess $\mathrm{Ba}$ in the sample. $\mathrm{BaF}^{+}$could potentially substitute for $\mathrm{Cs}^{+}$to stabilize the pollucite structure. Further studies are needed to test the speculation. The Ba-doped pollucite shows a local perfect pollucite crystal structure with a lattice constant of $1.26 \mathrm{~nm}$, slightly smaller than the database value $(1.368 \mathrm{~nm})$. The Ba-containing precipitates at the grain boundaries consist of mainly $\mathrm{Si}$ and $\mathrm{O}$ in addition to $\mathrm{Ba}$, which are crystalline. Preliminary data analysis suggests that the crystal is different from the pollucite phase. Further studies are planned to determine the crystal structure. Pollucite phase is also found be to susceptive to $300 \mathrm{keV}$ electron beam irradiation and can be readily amorphized. Significant $\mathrm{Cs}$ out-diffusion and release from the $\mathrm{F}^{+}$ion implanted and amorphized sample are observed. This process occurs predominantly during ion implantation at $673 \mathrm{~K}$. Further diffusion and surface accumulation of Cs proceeds during the post thermal annealing at higher temperatures up to $1073 \mathrm{~K}$, but significant Cs release is not observed during the thermal process. In-situ $\mathrm{He}^{+}$ion irradiation study suggests that prior to amorphization, Cs loss is negligible during ion irradiation. The essential cation constituents $(\mathrm{Cs}, \mathrm{Ba}, \mathrm{Al}$ and $\mathrm{Si}$ ) in the amorphized material are found in oxide or compound states, rather than in elemental states. There is no evidence showing formation of metal aggregates or valence change of all the elements in the amorphized material. 


\section{Theory}

As for our previous study of model waste form of $\mathrm{SrTiO}_{3}$ for fission product ${ }^{90} \mathrm{Sr}$, we pursue a combined theoretical/experimental approach to study of decay processes of a ${ }^{137} \mathrm{Cs}$-containing aluminosilicate pollucite waste form. The theoretical portion of this report focuses on the atomistic simulation of pure and Ba-doped pollucite single crystals. Where possible, we direct the theoretical effort so as to be consistent with the ion-implantation experiments. Atomic configurations and total energies were determined for stoichiometric and defected pollucite unit cells using density functional theory. Reference energies for all the system constituents, $\mathrm{Ba}$ and $\mathrm{Cs}$ metal, cubic $\mathrm{BaO}$ and rhombohedral $\mathrm{Cs}_{2} \mathrm{O}, \mathrm{O}_{2}$ were also calculated. Spin-orbit and finite-temperature effects were not included.

The primitive unit cell for the pollucite structure has 160 atoms, 16 formula units of the ideal $\mathrm{CsAlSi}_{2} \mathrm{O}_{6}$ composition, for a full formula of $\mathrm{Cs}_{16} \mathrm{Al}_{16} \mathrm{Si}_{32} \mathrm{O}_{96}$. The $\mathrm{Si}$ and $\mathrm{Al}$ atoms are distributed randomly throughout the pollucite framework. We investigated the effect of the Al distribution by first identifying several structural subsets of the silicate network in the analogous pure $\mathrm{SiO}_{2}$ zeolite framework, and then distributing $\mathrm{Al}$ atom in this network according to these structural subsets. We identified 5 distinct $\mathrm{Al}$ distributions with this approach. The energy differences among these five models are quite small. We conclude that the precise location of the $\mathrm{Al}$ ions has only a minor effect on the system energetics, and we therefore proceeded with a single configuration for the rest of the calculations.

Calculations were performed with 1 to $16 \mathrm{Ba}$ ions substituted for Cs. Ba was either left uncompensated, or was compensated by either excess oxygen or Cs vacancies. The results show that with the decay of Cs to $\mathrm{Ba}$, the removal (or escape) of $\mathrm{Cs}$ from the pollucite crystal is energetically unfavorable. The lowest equilibrium energy is achieved by precipitating half the $\mathrm{Ba}$ (as metal, or as $\mathrm{BaO}$ if oxygen is supplied by environment) so the remaining $\mathrm{Ba}$ is compensated by $\mathrm{Cs}$ vacancies. This means that as the waste form decays, remaining Cs should stay trapped. However, information about ion mobilities is still needed.

Finally, we find that at equilibrium, $\mathrm{Ba}$ and vacancies tend to segregate into Ba-rich regions. This is consistent with the segregation of $\mathrm{Ba}$ that is seen in the analysis of the Ba-doped pollucite sample provided by Sandia Laboratory. This raises questions about the effects of Ba precipitation in the decaying waste form.

Further investigation that includes explicit inclusion of additional excess oxygen, the presence of fluorine ions, and consideration of aluminosilicate backbone defects is needed for a complete correlation to the experimental data. In particular, a description of defect formation and evolution in crystal network is needed to explore the effects of irradiation-induced amorphization. As stated above, theoretical results show that Cs release is unlikely for intact crystalline pollucite. Based on these calculations and the experimental data, we hypothesize that the amorphization process is critical to the migration and release of $\mathrm{Cs}$ in the $\mathrm{F}^{+}$implanted samples. 


\section{CONTENTS}

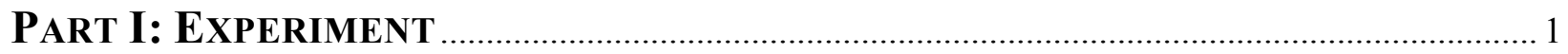

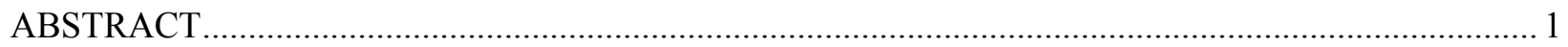

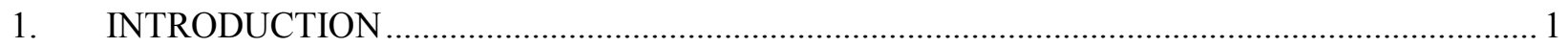

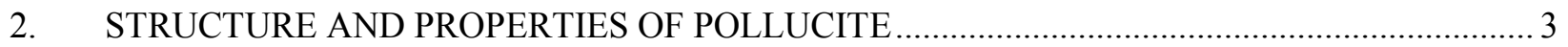

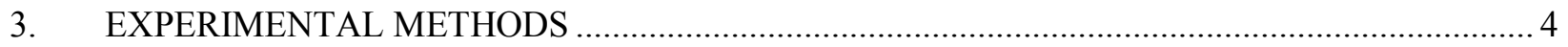

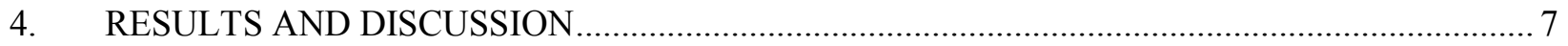

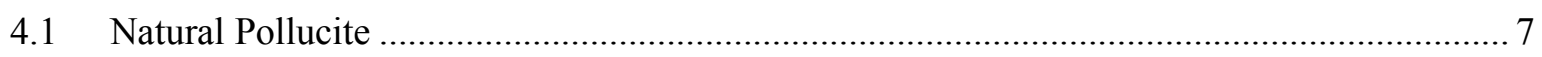

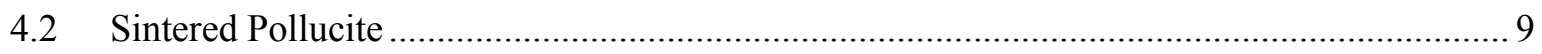

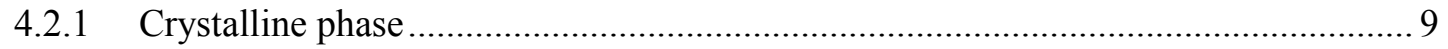

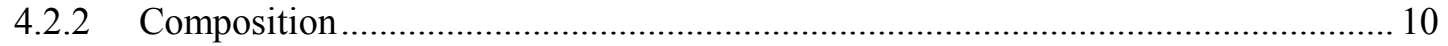

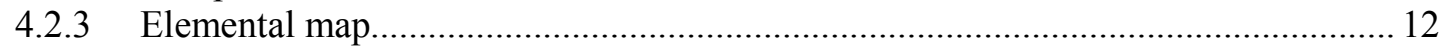

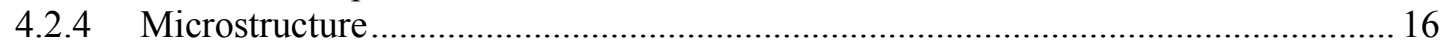

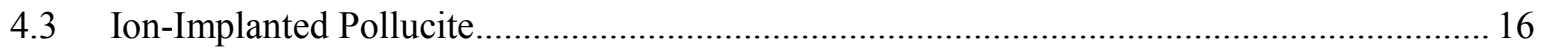

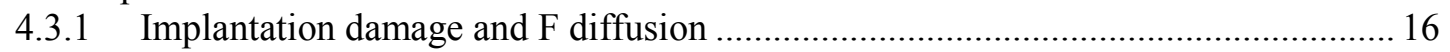

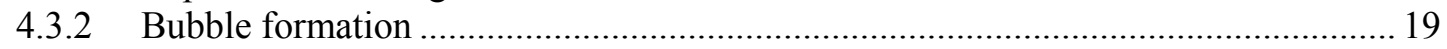

4.3.3 Atomic arrangements of pollucite and Ba-containing precipitates .......................... 20

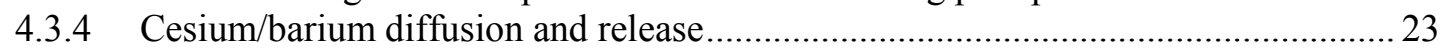

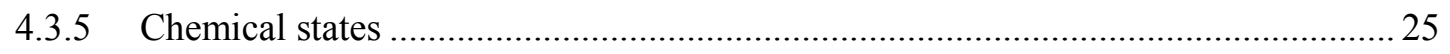

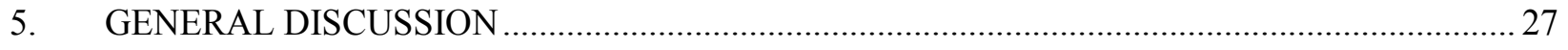

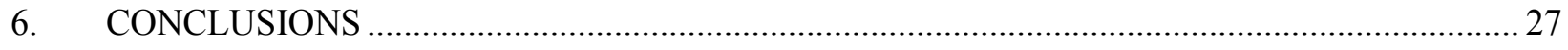

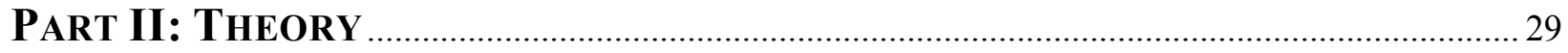

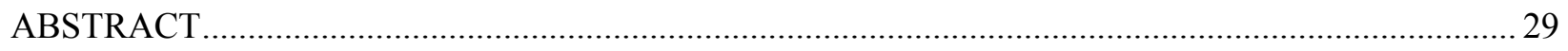

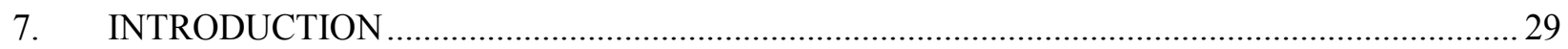

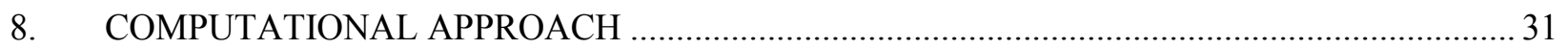

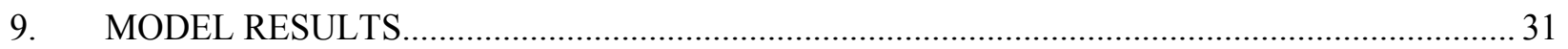

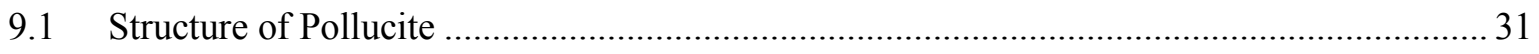

9.2 Ba Substitution and the Predicted Fate Ba Atoms on Cs Sites in Pollucite .......................... 33

9.2.1 Point defect formation energies, and vacancy-Ba complex formation ....................... 33

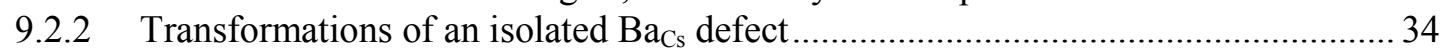

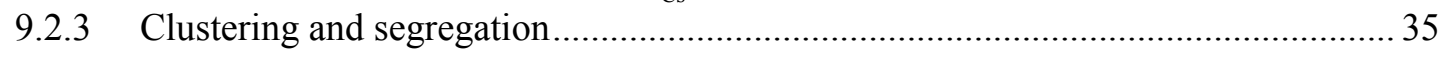

9.3 Alternate Chemical Formulation: Fe-containing Pollucite Structures ................................ 36

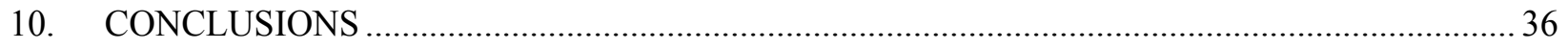

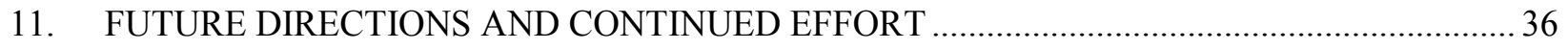

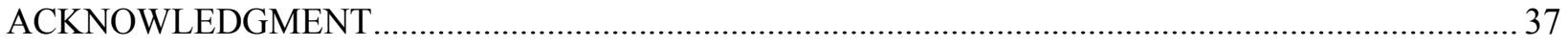

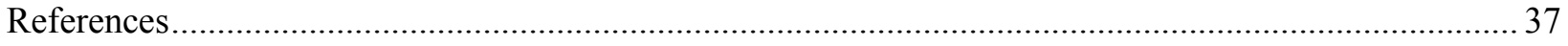




\section{ACRONYMS}

\begin{tabular}{|c|c|}
\hline BSE & Backscattering Electron \\
\hline CBM & Conduction Band Minimum \\
\hline DFT & Density Functional Theory \\
\hline EDS & Energy-dispersive X-ray Spectroscopy \\
\hline EMSL & Environmental Molecular Sciences Laboratory \\
\hline EPMA & Electron Probe Microanalyzer \\
\hline FIB & Focused Ion Beam \\
\hline FOV & Field of View \\
\hline GGA & Generalized Gradient Approximation \\
\hline GIXRD & Grazing-angle Incidence X-ray Diffraction \\
\hline HAADF & High-angle Annular Dark-field \\
\hline HIM & Helium Ion Microscope or Helium Ion Microscopy \\
\hline HRTEM & High-resolution Transmission Electron Microscopy \\
\hline ICP-AES & Inductively Coupled Plasma Atomic Emission Spectroscopy \\
\hline ICDD & The International Center for Diffraction Data \\
\hline LDA & Local Density Approximation \\
\hline Micro-XRD & Micro-beam X-ray Diffraction \\
\hline PDF & Powder Diffraction File \\
\hline PNNL & Pacific Northwest National Laboratory \\
\hline RBS & Rutherford Backscattering Spectrometry \\
\hline $\mathrm{RBS} / \mathrm{C}$ & Rutherford Backscattering Spectrometry under Ion-channeling Condition \\
\hline SEM & Scanning Electron Microscope or Scanning Electron Microscopy \\
\hline SIMNRA & Simulation of Nuclear Reaction Analysis \\
\hline SIMS & Secondary-ion Mass Spectroscopy \\
\hline SNL & Sandia National Laboratories \\
\hline SRIM & Stopping and Range of Ions in Matter \\
\hline TEM & Transmission Electron Microscope or Transmission Electron Microscopy \\
\hline WDS & Wavelength-dispersive X-ray Spectroscopy \\
\hline XPS & X-ray Photoelectron Spectroscopy \\
\hline $\mathrm{Z}$ & Atomic Number \\
\hline$\overline{Z A F}$ & Atomic Number, X-ray Absorption and Fluorescence \\
\hline
\end{tabular}




\title{
PART I: EXPERIMENT
}

\author{
Weilin Jiang \\ PNNL Contributors: Libor Kovarik, Bruce W. Arey, Zihua Zhu, Juan Liu, Tamas Varga, \\ Mark E. Bowden, Mark H. Engelhard, and Sandeep Manandhar \\ SNL Contributors: Tina M. Nenoff, Terry J. Garino, and David X. Rademacher
}

\begin{abstract}
This part summarizes the main experimental results obtained from January to September 2012 under project "Chemical and Charge Imbalance Induced by Radionuclide Decay: Effects on Waste Form Structure". In this initial effort, aluminosilicate pollucite $\mathrm{CsAlSi}_{2} \mathrm{O}_{6}$ is used as a model waste form for ${ }^{137} \mathrm{Cs}^{+}$that decays to ${ }^{137} \mathrm{Ba}^{2+}$ by $\beta^{-}$and $\gamma$ emissions. The decay-induced chemical effects are simulated in Ba-doped pollucite and studies of the charge effects on structure are attempted by introducing anions of $\mathrm{F}$ (and O) using ion implantation. Post thermal annealing was used to recover the lattice disorder and promote incorporation of the implanted ions into the crystal structure. Both natural and sintered pollucite samples are used in this study. A number of spectroscopic and microscopic methods have been employed for characterizations of the unimplanted and implanted/annealed pollucite, including x-ray diffraction (XRD), secondary ion mass spectroscopy (SIMS), Rutherford backscattering spectrometry (RBS), x-ray photoelectron spectroscopy (XPS), energy-dispersive x-ray spectroscopy (EDS), wavelength-dispersive xray spectroscopy (WDS), inductively coupled plasma atomic emission spectroscopy (ICP-AES), helium ion microscopy (HIM) and transmission electron microscopy (TEM).
\end{abstract}

The natural pollucite sample is found to have a poor crystalline quality for ion-channeling studies. The assintered samples of $\mathrm{CsAlSi}_{2} \mathrm{O}_{6}, \mathrm{Cs}_{0.9} \mathrm{Ba}_{0.05} \mathrm{AlSi}_{2} \mathrm{O}_{6}$, and $\mathrm{Cs}_{0.9} \mathrm{Ba}_{0.1} \mathrm{AlSi}_{2} \mathrm{O}_{6}$ show pollucite structure without water and their compositions are nearly stoichiometric. However, minor phases of $\mathrm{Al}$ and/or Si oxides are possible. Impurities, including $\mathrm{Na}$ and $\mathrm{Ca}$ in the samples, are identified. The results from this study indicate that aluminosilicate pollucite can be readily amorphized under ionizing radiation, such as electron and ion irradiation. The critical temperature for amorphization is above $673 \mathrm{~K}$ under $\mathrm{F}^{+}$ion irradiation. Cesium in the amorphized pollucite is found to be diffusive. A significant amount of Cs release is observed from the sample during $\mathrm{F}^{+}$ion irradiation at $673 \mathrm{~K}$. The implanted $\mathrm{F}$ is mobile and forms gas bubbles in $\mathrm{Cs}_{0.9} \mathrm{Ba}_{0.05} \mathrm{AlSi}_{2} \mathrm{O}_{6}$ at temperatures as low as $673 \mathrm{~K}$. However, formation of $\mathrm{F}_{2}$ bubbles does not occur in $\mathrm{Cs}_{0.9} \mathrm{Ba}_{0.1} \mathrm{AlSi}_{2} \mathrm{O}_{6}$ even at temperatures as high as $1073 \mathrm{~K}$. The results suggest that $\mathrm{F}$ implants may form chemical bonds, such as the one in $\mathrm{BaF}$, which could potentially substitute for Cs to stabilize the pollucite structure. For as-doped pollucite, Ba-containing precipitates are observed with mainly $\mathrm{Si}$ and $\mathrm{O}$ in addition to $\mathrm{Ba}$. They are located at the grain boundaries of the pollucite grains. The exact crystal structure of the precipitates has yet to be determined, but preliminary data analysis shows that the phase is different from pollucite. Near the crystalline/amorphous interface, there is a slight distortion of the pollucite structure. It remains to be investigated that whether $\mathrm{Ba}$ and $\mathrm{F}$ have been incorporated into the pollucite structure. Metal phases of $\mathrm{Cs}$ and $\mathrm{Ba}$ are not observed in the amorphized material. Si and Al are present as oxide states. There is no evidence suggesting valence change in all the elements. A general discussion is also provided in this report.

\section{INTRODUCTION}

Fission products of uranium in spent fuels from commercial nuclear power plants contain large yields of ${ }^{137} \mathrm{Cs}$ and ${ }^{90} \mathrm{Sr}$ that are highly radioactive with half-lives of 30.2 and 29.1 years, respectively [Lide 2003]. As a result of nucler decay and self-electron irradiation, these two radionuclides are primarily responsible for the heat generation in the spent fuel during the first 300 years. They need to be separated from the complex composition for confinement, long-term storage or permanent disposal. Removal of ${ }^{137} \mathrm{Cs}$ and 
${ }^{90} \mathrm{Sr}$ from the spent fuel could significantly reduce repository size for nuclear wastes [Forsberg 2000]. In order to separate the radionuclides, spent fuels are chemically reprocessed by ion exchange for ${ }^{137} \mathrm{Cs}$ and by solvent extraction for ${ }^{90} \mathrm{Sr}$ [Fortner 1999]. Prior to disposal, the radionuclides must be immobilized in a solid form to prevent their release to the environment. Ideal waste forms are mechanically strong, chemically stable, resistant to self-irradiation-induced damage, and highly thermally conductive. Over the past two years, we have focused our study on $\mathrm{SrTiO}_{3}$ as a model waste form for ${ }^{90} \mathrm{Sr}$ under this project and the results have been reported [Jiang 2011; Jiang 2012a; Jiang 2012b; Jaffe 2012]. This document summarizes the results from our recent study of potential ${ }^{137} \mathrm{Cs}$ waste form of aluminosilicate pollucite.

Isotope ${ }^{137} \mathrm{Cs}$ decays to an excited state of ${ }^{137 \mathrm{~m}} \mathrm{Ba}$ by emission of a $\beta^{-}$particle with a probability of $94.6 \%$ and quickly transforms to the ground state of ${ }^{137} \mathrm{Ba}\left(\mathrm{T}_{1 / 2}=2.6 \mathrm{~min}\right)$ by giving off a $0.662 \mathrm{MeV} \gamma$ photon. It can also directly decay to ${ }^{137} \mathrm{Ba}$ with decay energy of $1.176 \mathrm{MeV}$, but the probability is smaller (5.4\%). In addition to generation of heat during the processes, the decay changes the cation valence and ionic radius in the host structure, potentially leading to instability of its microstructure and an increase in the mobility or diffusivity of the radionuclide. Pollucite compositions, such as aluminosilicate pollucite $\mathrm{CsAlSi}_{2} \mathrm{O}_{6}$, have been attracting extensive research efforts over the past decades as a potential host for radionuclide ${ }^{137} \mathrm{Cs}$. It is considered as a potential waste form for immobilization of ${ }^{137} \mathrm{Cs}$ because of its low leach rates and good thermal stability [Strachan 1979]. However, radiation resistance and decay effects in pollucite must be investigated prior to management decision. A previous TEM study [Strachan 1997] shows that a diluted, aged sample of ${ }^{137} \mathrm{CsAlSi}_{2} \mathrm{O}_{6} \cdot 0.5 \mathrm{H}_{2} \mathrm{O}$ is susceptive to electron irradiation induced amorphization at an energy as low as $200 \mathrm{keV}$. Volatilization of Cs in the sample under the electron irradiation was also observed. The dose rate under TEM was much higher than for an actual waste under the normal $\beta^{-}$decay scenario and the total applied dose was equivalent to the accumulation from ${ }^{137} \mathrm{Cs}$ decay for several thousand years. Since this time length is much greater than the half-life of ${ }^{137} \mathrm{Cs}$, the performance of the waste form needs to be further assessed. A later study performed by the same research group [Fortner 1999] found that an aged ${ }^{137}$ Cs-containing pollucite after decay of nearly $16 \%$ of the total ${ }^{137} \mathrm{Cs}$ over the elapsed 20 years exhibited a homogenous, crystalline matrix with no evidence of distinct Ba phases or exsolution phenomena. It should be noted that the initial radioactive pollucite contained only a small mass fraction (0.0375) of radionuclide ${ }^{137} \mathrm{Cs}$ substitution for stable ${ }^{133} \mathrm{Cs}$. Thus, the total Ba concentration in the aged sample was small. On the other hand, Hess [Hess 2000] found a slight increase in the volume from $0.5-1 \%$ in the $\beta^{-}$irradiated stoichiometric pollucite structure that was doped with ${ }^{137} \mathrm{Cs}$. Pollucite possesses a low thermal expansion coefficient of $1.3 \times 10^{-6} \mathrm{~K}^{-1}$ from 296 to $1273 \mathrm{~K}$ and [Yanase 2003]. The value is smaller compared to those $\left(2.4 \times 10^{-6}\right.$ and $\left.3.0 \times 10^{-6} \mathrm{~K}^{-1}\right)$ in differently sintered pollucite and pollucite made through $\mathrm{Cs}^{+}$ion exchange of lithium and sodium aluminosilicates, respectively [Richerson 1972]. In general, pollucite has a low thermal expansion coefficient that depends on its synthesis method [Holand 2012]. Synthesis of high-quality pure and doped pollucite compositions has been an active subject of research [Yanagisawa 1987; Garino 2009; Kaminski 2009], in addition to studies of natural pollucite minerals [Ogorodova 2003; Sanchez-Valle 2010].

Our experimental approach is to simulate the chemical effects due to radioisotope decay by doping $\mathrm{Ba}$ into a non-radioactive ${ }^{133} \mathrm{CsAlSi}_{2} \mathrm{O}_{6}$ pollucite structure and to study charge effects by introducing chargecompensating ions $\mathrm{F}$ (and $\mathrm{O}$ ) using ion implantation. Without specific concerns of possible radiological contamination, the simulated samples can be characterized using all available methods necessary to better understand the fundamental processes and decay effects on structure. The ion-implantation method is effective both as a direct substitution technique and as a charge compensation technique, which have been demonstrated for $\mathrm{Zr}^{+}$and $\mathrm{O}^{+}$ion co-implanted $\mathrm{SrTiO}_{3}$ [Jiang 2012a; Jiang 2012b]. Post thermal annealing is designed to recover implantation defects and promote incorporation of the implants into the crystal structure. Unlike actinide waste forms where $\alpha$ particles and daughter recoils produce significant lattice damage, effects of electron and $\gamma$-ray irradiation in real pollucite waste form are expected to be small in terms of atomic displacements. The primary decay effects on the pollucite microstructure could be 
associated with change in chemistry, including charge imbalance and change in ionic radii. The overall microstructures in the implanted/annealed pollucite are expected to be different from the real waste form because of the implantation-induced lattice disorder, including excess Cs interstitials (displaced from lattice sites that could be occupied by dopants and implants) and extended defects (formed during hightemperature annealing). However, the irradiated/annealed microstructure is not identical everywhere, and in some local regions the microstructure has a low concentration of atomic displacements and should be dictated primarily by the chemistry of the available elements in the environment. The stable microstructure in this region should resemble that of the real waste form in a thermodynamic equilibrium state. For ${ }^{137} \mathrm{CsAlSi}_{2} \mathrm{O}_{6}$, disordering rate due to beta decay is extremely small. The average time between two consecutive atomic displacements at a specific site or its nearby sites is much longer than that needed for the structure to reach thermal equilibrium. We attempt to study Ba-doped $\mathrm{CsAlSi}_{2} \mathrm{O}_{6}$ structure and compare it to selected local structures after $\mathrm{F}^{+}$implantation and thermal annealing.

\section{STRUCTURE AND PROPERTIES OF POLLUCITE}

Pollucite, discovered in 1846, is a member of zeolite group containing up to $47 \%$ Cs by weight. Aluminosilicate pollucite is one of the common crystal types with the chemical formula $\mathrm{CsAlSi}_{2} \mathrm{O}_{6}$. Natural pollucite minerals are found in lithium-rich granite pegmatites, usually with water $\left(\mathrm{H}_{2} \mathrm{O}\right)$
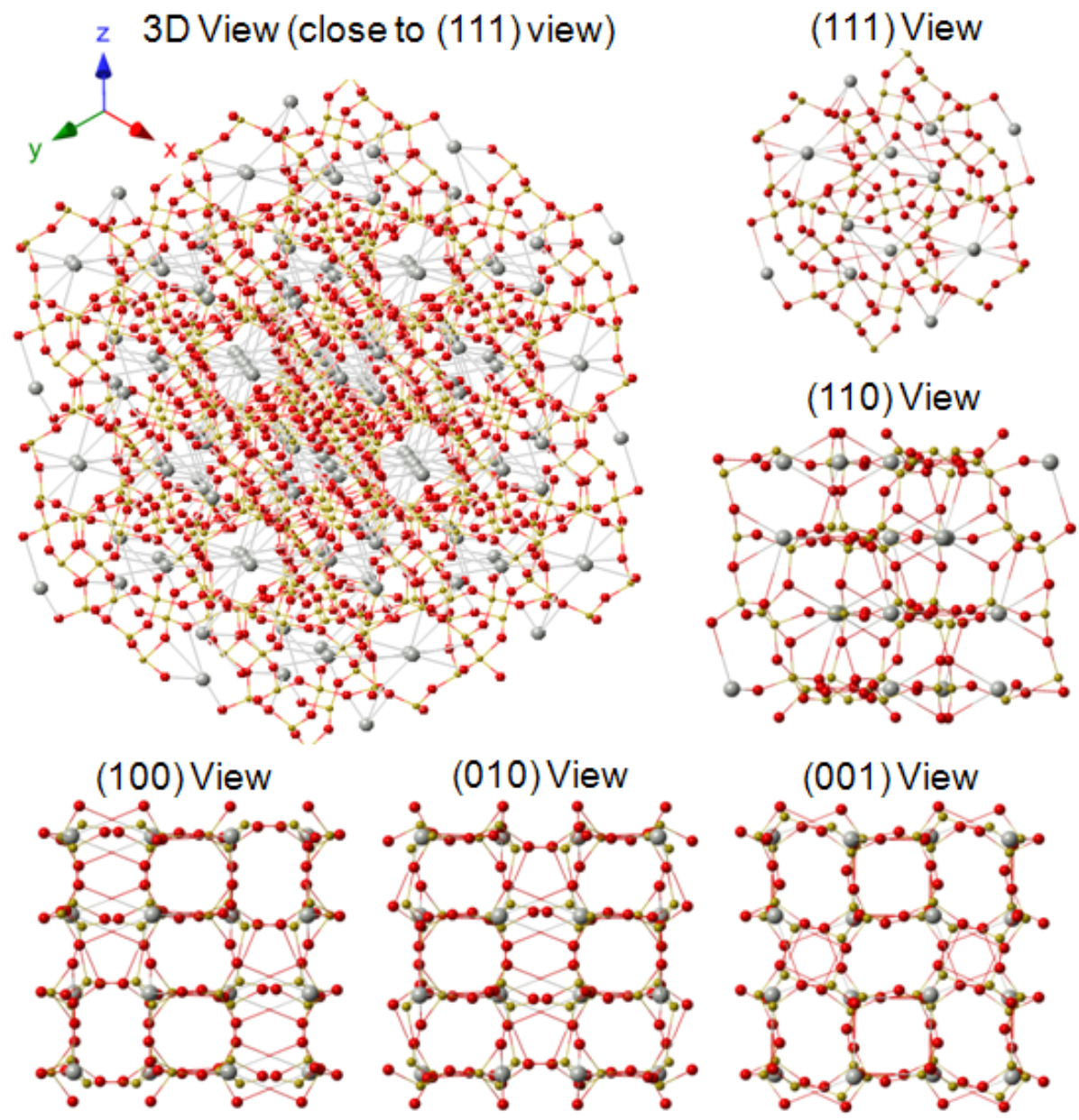

Figure 1. Three-dimensional and planar views of the crystal structure of cubic $\mathrm{CsAlSi}_{2} \mathrm{O}_{6}$ pollucite (Cs: grey; $\mathrm{Al}$ or Si: golden; O: red). 
attachment and with $\mathrm{Fe}, \mathrm{Ca}, \mathrm{Rb}$ and $\mathrm{K}$ as common substituting element. The composition crystallizes in the isometric-hexoctahedral system as colorless, white, gray, or rarely pink, blue and pale violet masses. Pollucite is the most refractory silicate known, exhibiting a melting point above $2173 \mathrm{~K}$ [Holand 2012]. Well formed crystals are rare in nature and large, high-quality single crystals have not yet been synthesized at laboratory. Aluminosilicate pollucite also known as Cs-leucite, has a Mohs hardness of 6.5 and a specific gravity of $2.93 \mathrm{~g} / \mathrm{cm}^{3}$ [Sanchez-Valle 2010]. It is very brittle with uneven to conchoidal fracture. Good cleavage has never been observed. The crystal structure of $\mathrm{CsAlSi}_{2} \mathrm{O}_{6}$ pollucite has the cesium analogue of Analcime with a cubic symmetry (space group: Ia3d; a $=1.3682(3) \mathrm{nm}, \mathrm{Z}=16$ ) at temperatures above $\sim 373 \mathrm{~K}$. The atomic arrangement of dry $\mathrm{CsAlSi}_{2} \mathrm{O}_{6}$ is illustrated in Fig. 1, where the three-dimensional (for 8 unit cells) and various low-index planar (for 1 unit cell) projection views are provided. The structure consists of a network of vertex-sharing $(\mathrm{Al}, \mathrm{Si}) \mathrm{O}_{4}$ tetrahedra with Cs contained in wide channels that are parallel to the $<111>$ axis. At temperatures below $373 \mathrm{~K}$, pollucite transforms to tetragonal phase with the c/a ratio of only 1.0051 [Palmer 1997]. In a separate report [Yanase 2003], phase transition from tetragonal structure in the temperature range from 93 to $248 \mathrm{~K}$ to cubic structure from 248 to $273 \mathrm{~K}$ was observed. The cubic structure in the high temperature range is probably the pseudo one referred to in [Palmer 1997]. We will consider pollucite structure at room temperature as a pseudo-cubic or cubic structure below for simplicity.

\section{EXPERIMENTAL METHODS}

Both natural mineral and synthesized samples of aluminosilicate pollucite are used in this study. A thin matrix of feldspar covered by a druse of tiny pollucite and well isolated lager pollucite crystals was obtained from Marin Mineral in Larkspur, California, as shown in Fig. 2(a). This mineral rock was collected in Shengus Mine, Skardu district, Pakistan. The straight line in Fig. 2(a) is an artifact from the scanned hardcopy, but is not on the mineral. A crystal ball of $\sim 10 \mathrm{~mm}$ in diameter (circled in Fig. 2(a)) was removed from the mineral bulk, cut using a diamond saw, and surface polished using sandpaper, as shown in Fig. 2(b). The backside was marked with "3" in black that was not the original color of the mineral. However, an "L" shaped crack in the otherwise transparent sample is visible. Synthesis of aluminosilicate pollucite was conducted at Sandia National Laboratories (SNL) in Albuquerque, NM.
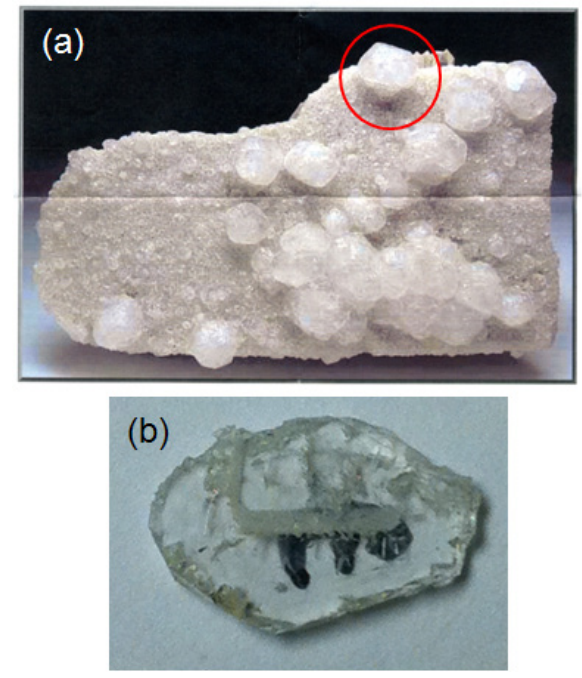

Figure 2. (a) The as-obtained natural aluminosilicate pollucite and (b) the cut/polished plate from the crystal ball circled in (a). The size of the sample in (b) is about $6 \times 10 \mathrm{~mm}^{2}$.

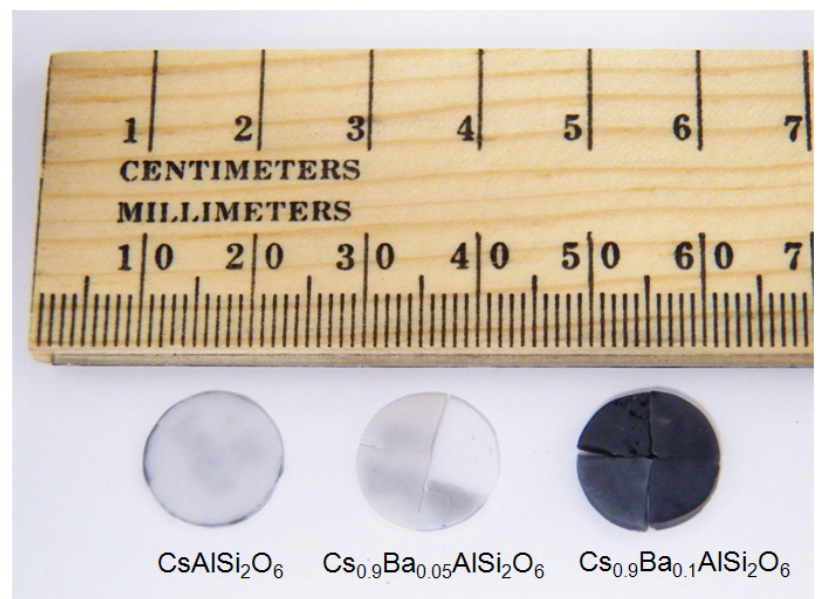

Figure 3. Pollucite pellets of $\mathrm{CsAlSi}_{2} \mathrm{O}_{6}$, $\mathrm{Cs}_{0.9} \mathrm{Ba}_{0.05} \mathrm{AlSi}_{2} \mathrm{O}_{6}$, and $\mathrm{Cs}_{0.9} \mathrm{Ba}_{0.1} \mathrm{AlSi}_{2} \mathrm{O}_{6}$ synthesized at Sandia National Laboratories in Albuquerque, NM. The as-sintered samples are disks of about $12 \mathrm{~mm}$ in diameter. 
Table 1. Ion implantation and thermal annealing conditions for Ba-doped pollucite: $\mathrm{Cs}_{0.9} \mathrm{Ba}_{0.05} \mathrm{AlSi}_{2} \mathrm{O}_{6}$ and $\mathrm{Cs}_{0.9} \mathrm{Ba}_{0.1} \mathrm{AlSi}_{2} \mathrm{O}_{6}$.

\begin{tabular}{lccclccc}
\hline \hline ID & Ion & $\begin{array}{c}\text { Energy } \\
(\mathrm{MeV})\end{array}$ & $\begin{array}{c}\text { Fluence } \\
\left(10^{16} \mathrm{~cm}^{-2}\right)\end{array}$ & $\begin{array}{c}\text { O or F Ratio } \\
\text { at Peak }\end{array}$ & $\begin{array}{c}\mathrm{T}_{\text {imp }} \\
(\mathrm{K})\end{array}$ & $\begin{array}{c}\mathrm{T}_{\text {ann }} \\
(\mathrm{K})\end{array}$ & $\begin{array}{c}\mathrm{t}_{\text {ann }} \\
(\mathrm{hr})\end{array}$ \\
\hline$\# 1$ & ${ }^{16} \mathrm{O}^{+}$ & 1.2 & 0.6 & $0.2 \%$ & 673 & --- & -- \\
$\# 2$ & ${ }^{16} \mathrm{O}^{+}$ & 1.2 & 13.6 & $5 \%$ & 573 & 1423 & 10 \\
$\# 3$ & ${ }^{19} \mathrm{~F}^{+}$ & 1.2 & 8.2 & $3 \%$ & 673 & 1423 & 10 \\
$\# 4$ & ${ }^{19} \mathrm{~F}^{+}$ & 1.2 & 13.6 & $5 \%$ & 673 & 873,1073 & 4 \\
\hline \hline
\end{tabular}

Hydrothermal and calcining procedures [MacLaren 1999] were adopted to synthesize pollucite powers with various percentages of Ba doping, followed by hot press into high-density disks at $1773 \mathrm{~K}$ and 6000 psi for 1 hour [Nenoff 2011]. Three series of the sintered pollucite samples with the surface mechanically polished have been analyzed in this study, i.e., CsAlSi $\mathrm{O}_{6}, \mathrm{Cs}_{0.9} \mathrm{Ba}_{0.05} \mathrm{AlSi}_{2} \mathrm{O}_{6}$ and $\mathrm{Cs}_{0.9} \mathrm{Ba}_{0.1} \mathrm{AlSi}_{2} \mathrm{O}_{6}$, as shown in Fig. 3. The $\mathrm{Cs}_{0.9} \mathrm{Ba}_{0.05} \mathrm{AlSi}_{2} \mathrm{O}_{6}$ sample is attempted to have two $\mathrm{Cs}$ ions replaced by one $\mathrm{Ba}$ ion and one neighboring vacancy to have a change balance configuration [Nenoff 2011], while $\mathrm{Cs}_{0.9} \mathrm{Ba}_{0.1} \mathrm{AlSi}_{2} \mathrm{O}_{6}$ is charge imbalanced with an excess $\mathrm{Ba}$ concentration. Due to the physical obstacles involved in producing negative $\mathrm{Ba}^{-}$ions with a SNICS source for acceleration by the tandem ion accelerator at PNNL, $\mathrm{Ba}^{+}$ion implantation to a high dose in the undoped pollucite samples were not performed. Although oxide cathodes were made and attempted, the $\mathrm{BaO}^{-}$current was very small $(\sim 10 \mathrm{nA})$ at the low-energy Faraday cup. $\mathrm{Ba}^{+}$ion implantation at PNNL may be possible with specifically made hydride cathodes (to produce $\mathrm{BaH}^{-}$). However, the cathodes are not stable under the ambient conditions and thus not commercially available. In this report, only Ba-doped samples were used for $\mathrm{F}^{+}\left(\right.$and $\left.\mathrm{O}^{+}\right)$ion implantation studies.

Ion implantation and sample characterization were performed in the Environmental Molecular Sciences Laboratory (EMSL) at the Pacific Northwest National Laboratory (PNNL). Ion implantation was conducted with a NEC 9SDH-2 pelletron 3.0 MV electrostatic tandem accelerator [Thevuthasan 1999]. An elevated temperature for $\mathrm{F}^{+}$(and $\mathrm{O}^{+}$) implantation was attempted to minimize the damage production. There are no data in the literature reporting the disordering behavior in $\mathrm{CsAlSi}_{2} \mathrm{O}_{6}$ and the critical temperature for amorphization in the material is currently unknown. For both $5 \%$ and $10 \% \mathrm{Ba}$ doped samples $\left(\mathrm{Cs}_{0.9} \mathrm{Ba}_{0.05} \mathrm{AlSi}_{2} \mathrm{O}_{6}\right.$ and $\left.\mathrm{Cs}_{0.9} \mathrm{Ba}_{0.1} \mathrm{AlSi}_{2} \mathrm{O}_{6}\right)$, an atomic percentage of up to $5 \% \mathrm{~F}$ (or $\mathrm{O}$ ) at the profile peak was implanted into the materials. A beam rastering system was utilized to achieve uniform implantation over an area of $14 \mathrm{~mm} \times 14 \mathrm{~mm}$ with an average ion flux on the order of $5 \times 10^{12} \mathrm{~F}^{+} / \mathrm{cm}^{2} / \mathrm{sec}$ (and $4 \times 10^{12} \mathrm{O}^{+} / \mathrm{cm}^{2} / \mathrm{sec}$ ). Sample temperature was measured at the front surface through the use of a customized chromel-alumel thermocouple system. A total of four runs for ion implantation were conducted and in each run, both doped samples were implanted under the identical conditions. The ion implantation conditions are given in Table 1. The implanted samples were cut into smaller pieces for thermal annealing at different temperatures. For annealing at 873 and $1073 \mathrm{~K}$, both temperature ramp-up times were 1 hour and the annealing time was 4 hours. For annealing at $1423 \mathrm{~K}$, the ramp time for heating was 2 hours and the annealing time was 10 hours. In both cases, cooling took over 10 hours till the sample temperature in the furnace was below $343 \mathrm{~K}$. All the furnace annealing was conducted in a flowing Ar gas environment. The thermal annealing conditions are also given in Table. 1.

Computer simulation of $\mathrm{F}^{+}$(and $\mathrm{O}^{+}$) ion implantation in $\mathrm{CsAlSi}_{2} \mathrm{O}_{6}$ was performed using the Stopping and Range of Ions in Matter (SRIM) code [Ziegler 1985] for the depth profiles of damage production and implanted species. The results for $\mathrm{F}^{+}$ion implantation used in this study are shown in Fig. 4 . In the simulation, the specific gravity of the material was taken as $2.9 \mathrm{~g} / \mathrm{cm}^{3}$, while the threshold displacement 
energies for all the sublattices were assumed to be $50 \mathrm{eV}$. Since the data are currently unavailable, the assumption is not expected to be accurate and the simulation results can only reflect the shape of the displacement profile, but not the absolute value of the displacement rates that strongly depend on the threshold displacement energies. Simulations for more accurate damage profile can be obtained for estimation of dose in displacements per atom once the threshold energies are determined. However, the inaccurate threshold energies do not affect the relative comparison and data interpretation in this study. The depth profiles of the implanted F only weekly depend on the energy values and can provide a reasonable

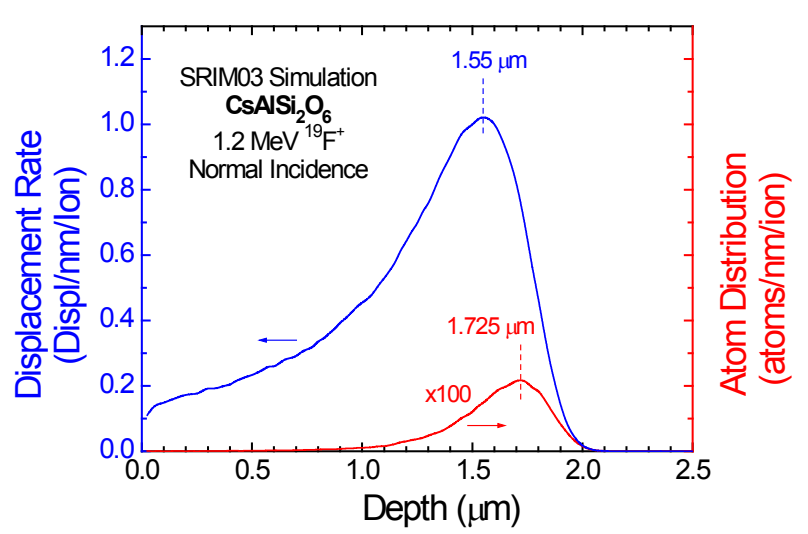
prediction within the accuracy of the ion stopping powers at low energies. The simulation results indicate that the depth profile of the implanted $\mathrm{F}$ is peaked at $1.725 \mu \mathrm{m}$ and approaches to zero concentrations at $2.1 \mu \mathrm{m}$. The damage peak is located at $1.55 \mu \mathrm{m}$ with the end at $\sim 2 \mu \mathrm{m}$.

Sample characterizations were performed before, during and after implantation and annealing using various spectroscopic and microscopic methods. Micro-beam XRD (Micro-XRD), high-resolution XRD (HRXRD), and RBS under ion channeling conditions (RBS/C) are employed to assess the crystalline quality of the natural pollucite sample. Micro-XRD measurements were carried out with a Rigaku MicroMax $007 \mathrm{HF}$ system with a rotating $\mathrm{Cr}$ anode and a 2D image plate detector. HRXRD was performed on a Panalytical MRD system that was equipped with a parabolic x-ray mirror and 4-bounce $\mathrm{Ge}$ (220) monochromator to produce a parallel $\mathrm{Cu} \mathrm{K} \mathrm{K}_{\alpha 1}$ beam. The ion channeling experiments (RBS/C) were performed with $2.0 \mathrm{MeV} \mathrm{He}{ }^{+}$ions along the $<110>$ axial direction at a scattering angle of $150^{\circ}$. The orientation was initially mapped with the x-ray pole figure method. The random orientation spectrum was obtained at an off-axis orientation (polar $=7^{\circ}$ relative to $<110>$ axis) with rotating flip angles ranging from $-3^{\circ}$ to $+3^{\circ}$. The as-synthesized samples were analyzed for crystalline phases using symmetric scan XRD. Grazing-angle incidence XRD (GIXRD) was conducted to probe the implanted surface layer. The measurements were conducted with a Philips X'Pert multipurpose diffractometer with a fixed $\mathrm{Cu}$ anode operating at $45 \mathrm{kV}$ and $40 \mathrm{~mA}$. The depth profile of the implanted $\mathrm{F}$ was measured by use of a time-offlight SIMS (TOF-SIMS), where $\mathrm{O}_{2}^{+}$and $\mathrm{Bi}^{+}$ion beams were used for sputtering and analysis, respectively. The depth scale was calibrated by measuring the crater depth with a Veeco Dektak 150 stylus profilometer. Elemental mapping and composition analysis for the sintered samples were accomplished based on WDS and EDS, respectively, using JEOL JXA-8530F Field Emission Electron Probe Microanalyzer (EPMA) operating at $20 \mathrm{kV}$ with probe current of $20 \mathrm{nA}$. Spot mode was used for elemental mapping with a size of $60 \mathrm{~nm} \times 60 \mathrm{~nm}$ and dwell time of $200 \mathrm{~ms}$ per spot. Analyzing crystals for $\mathrm{O}, \mathrm{Si}, \mathrm{Al}, \mathrm{Ba}$ and $\mathrm{Cs}$ are LDE1, PETL, TAP, PETL and PETH at positions 111.423, 227.676, 90.803, 88.688 , and $92.966 \mathrm{~mm}$, respectively. The elemental ratio was also measured using ICP-AES at SNL and RBS at PNNL. The microstructures are examined using an advanced HIM and an aberration-corrected TEM. Compared to conventional scanning electron microscope (SEM), HIM has demonstrated a greatly enhanced imaging capability with a better surface sensitivity, higher spatial resolution, larger depth of field and sharper $\mathrm{Z}$ contrast. An accelerating voltage of 25 or $30 \mathrm{keV}$ was used for imaging with a probe current ranging from 5 to $15 \mathrm{pA}$. No conductive coatings were applied for the insulating pollucite materials and the charge compensation was achieved using an integrated electron gun. Cross-sectional thin specimens were prepared by use of focused ion beam (FIB, FEI Helios NanoLab 600), where 30 and 
$5 \mathrm{keV} \mathrm{Ga}{ }^{+}$ions were used for cutting and polishing the sample, respectively, and $1 \mathrm{keV} \mathrm{Ar}^{+}$ions for nano milling. The specimens were examined with a FEI aberration-corrected Titan 80-300 TEM (spatial resolution $=0.1 \mathrm{~nm}$ ) at $300 \mathrm{keV}$. XPS was also used to study the chemical states and impurities. The XPS experiment was performed based on the $\mathrm{Al} K_{\alpha}$ irradiation $(h v=1486.7 \mathrm{eV})$ in a clean base vacuum at $2 \times$ $10^{-7} \mathrm{~Pa}$ using oil-free turbo and ion pump systems. No ion sputtering was applied to avoid any changes in surface chemistry. Both wide scans in the binding energy range from 0 to $1350 \mathrm{eV}$ for a survey and fine scans for major elements were performed at an angle of $45^{\circ}$ relative to the normal x-ray incidence.

\section{RESULTS AND DISCUSSION}

\subsection{Natural Pollucite}

Figure 5 shows an XRD pattern from a symmetric $2 \theta$ $\omega$ scan for the natural pollucite shown in Fig. 2(b). There are three distinct diffraction peaks from (321), (431) and (752) with the strongest located at $2 \theta \approx 60^{\circ}$, as shown in the figure. From the powder diffraction database PDF\# 00-029-0407 for aluminosilicate pollucite, the relative diffraction intensities for the (321), (431) and (752) planes are 50\%, 4\%, and 4\%, respectively. The data in Fig. 5 suggests that the sample is a single crystal with surface oriented close to (752), corresponding to d-spacing of $0.15490 \mathrm{~nm}$. The presence of $(321)(d=0.3660 \mathrm{~nm})$ and $(431)(d=$ $0.2684 \mathrm{~nm})$ peaks is associated with the structural imperfection in the single crystal as one piece.

Since the two pieces of crystals are separated by a large crack and could misalign themselves, microXRD was performed for areas 1 and 2 on the two pieces, respectively. The diffraction images are shown

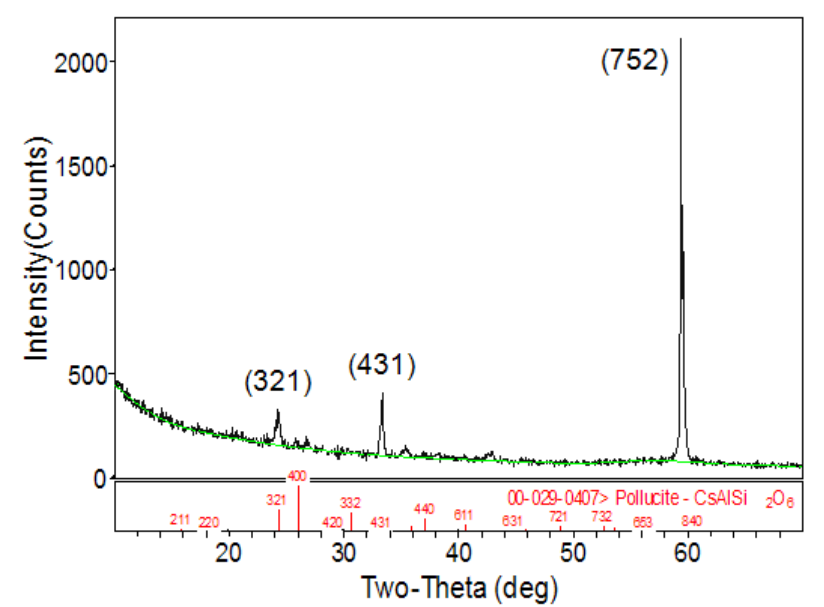

Figure 5. XRD pattern obtained from a symmetric scan for the pollucite sample shown in Fig. 2(b). The cut surface is determined to be close to the (752) plane.

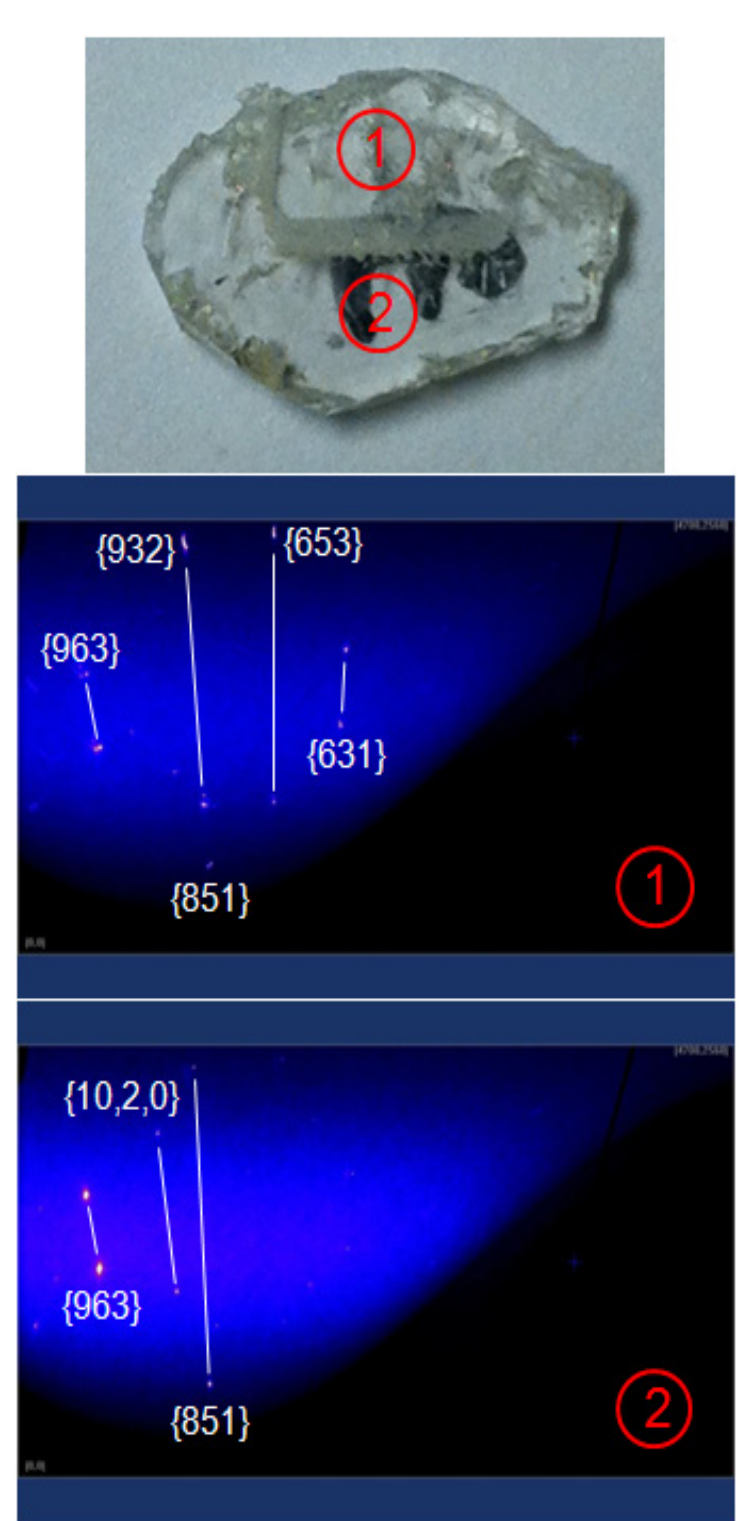

Figure 6. Micro-XRD diffraction images for the pollucite sample on the top panel in two areas that are separated by a crack. 
Fig. 6. The data exhibit discrete spots, instead of arches, confirming that both pieces are single crystals. The specific diffraction pattern strongly depends on how the sample is mounted. In area 1 , there are five sequences of bright diffraction spots that are connected with lines for equivalent planes in curved brackets, as indicated in the figure. In area 2 , only three sequences are observed, which are similar to those in area 1 . Since the diffraction intensity is very sensitive to their relative orientation, the similar diffraction pattern from the two pieces of single crystals suggests that they are only slightly misaligned.

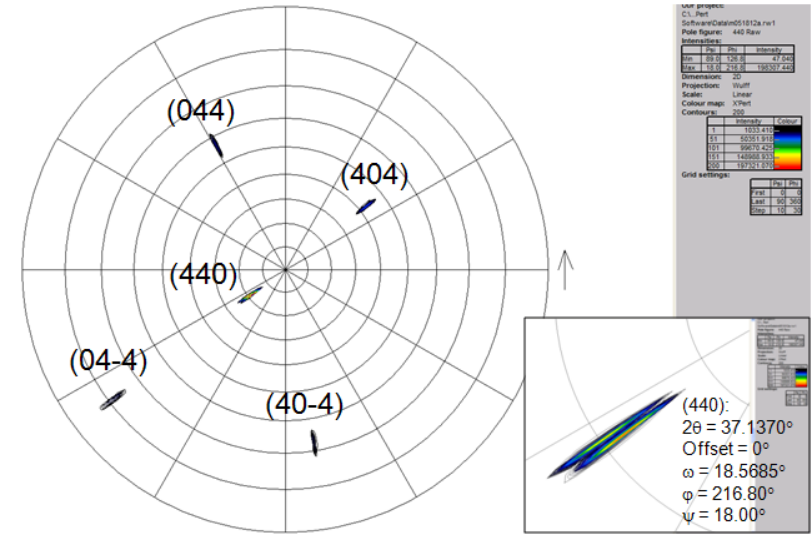

Figure 7. Pole figures of (440) in the pollucite sample shown in Fig. 2(b). Insert is a magnified view of the (440) pole. The distinctively distributed poles are consistent with the simulation pattern for single-crystal $\mathrm{CsAlSi}_{2} \mathrm{O}_{6}$. poles were mapped. Figure 7 shows distinct poles of (440) and its equivalent poles, reconfirming that the pollucite sample is a single crystal. Diffraction rings would be resulted if the material were polycrystalline. The inset in Fig. 7 is a magnified view of pole (440) that exhibits two closely located poles, probably from the two pieces of single crystals discussed above. These pole locations are predicted by a simulated projection of the cubic pollucite structure. Also predicted are the (400) and its equivalent poles measured from the experiment (data not shown).

To further assess the crystal quality, HRXRD was performed and the data are shown in Fig. 8. For (440) diffraction peak at $2 \theta=37.137^{\circ}$ shown in Fig. 8(a), there are fine structures consisting of three peaks with the most intense peak located at $37.3495^{\circ}$. This indicates that there are structural distortions or minor phases with different $d$ spacing values in the single crystal. Similarly, scan around $\omega$ for (440) plane leads to two separate peaks, each of which has fine structures. The two separate peaks originate probably from the two pieces of single crystals that are slightly misaligned, as observed above (Figs. 6 and 7). The fine structures in each peak indicate a mosaic structure in the single crystal, consistent with the observation in Fig. 5 that shows imperfection of the single crystals.
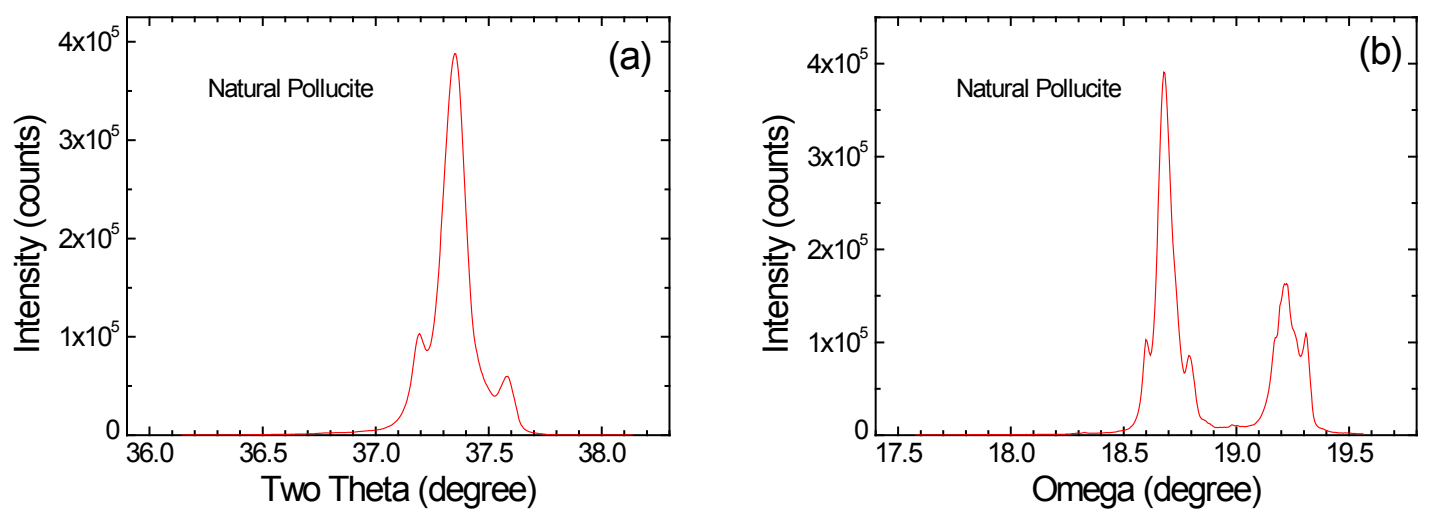

Figure 8. HRXRD patterns from (a) symmetric and (b) asymmetric scans around the (440) plane for the pollucite sample shown in Fig. 2(b), exhibiting fine structures and two separate peaks in the diffraction patterns. 
In order to evaluate the monocrystalline quality of the natural pollucite sample, ion channeling analysis with $2.0 \mathrm{MeV} \mathrm{He}^{+}$ions was performed along the $<110>$ axis (equivalent to the $<440>$ axis), determined by the pole figure measurement (Fig. 7). Search for the channeling direction was challenging and needed to expose the sample to a high dose. To avoid possible beam damage in the surface region, a fresh spot was used for collection of channeling spectrum after the sample was properly aligned with the incident beam. The channeling spectrum and a random spectrum are shown in Fig. 9. From the data, the minimum yield, $\chi_{\mathrm{min}}$, of $\sim 76 \%$ is determined. The minimum yield is defined as the ratio of the integrated yields from channeling and random spectra in the same narrow channel window near the surface. It is a

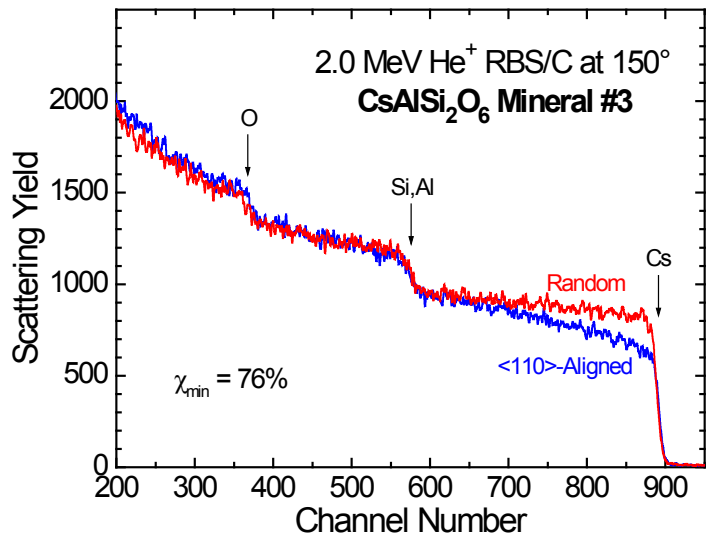

Figure 9. $<110>$-aligned and random RBS spectra of $2.0 \mathrm{MeV} \mathrm{He}^{+}$ions for the pollucite sample shown in Fig. 2(b). quantitative measure of monocrystalline quality.

For amorphous or polycrystalline materials, the minimum yield is $100 \%$. The typical $\chi_{\min }$ value for a good single crystal along a low-index axis is below 5\%. This natural pollucite sample has a large value that prevents from its utilization for a meaningful study of damage accumulation and recovery using ionchanneling methods. It remains to be studied whether other crystal balls in the mineral bulk (Fig. 2(a)) or a different one to be obtained have a better monocrystalline quality. Since this natural pollucite sample is not suitable for ion-channeling study, further measurements on the sample, including determination of composition, impurities, microstructure and minor phases, were not pursued. In the future, we may test a few more crystal balls with a better surface cut close to a low-index plane. The experimental procedure described above could be employed for future use to assess quality of this or other crystals and evaluate their usefulness for waste form studies.

\subsection{Sintered Pollucite}

\subsubsection{Crystalline phase}

All the undoped and Ba-doped samples have been structurally analyzed using XRD based on symmetric 20- $\omega$ scans. Representative XRD patterns for the as-sintered $\mathrm{CsAlSi}_{2} \mathrm{O}_{6}, \mathrm{Cs}_{0.9} \mathrm{Ba}_{0.05} \mathrm{AlSi}_{2} \mathrm{O}_{6}$ and
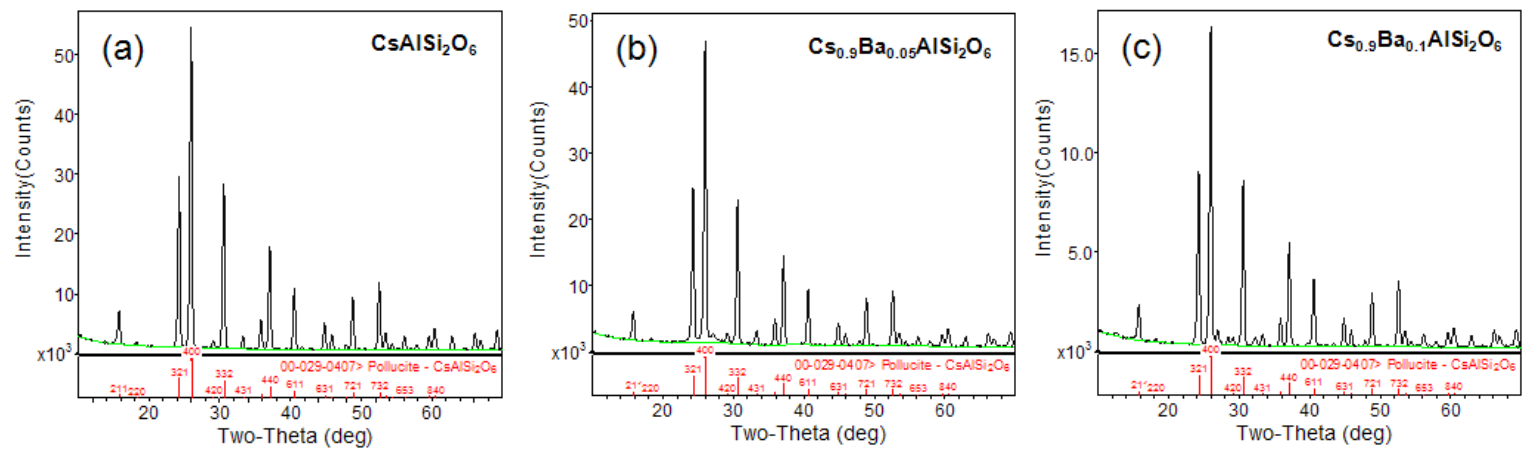

Figure 10. Typical XRD patterns from symmetric scans for the as-sintered $\mathrm{CsAlSi}_{2} \mathrm{O}_{6}$, $\mathrm{Cs}_{0.9} \mathrm{Ba}_{0.05} \mathrm{AlSi}_{2} \mathrm{O}_{6}$ and $\mathrm{Cs}_{0.9} \mathrm{Ba}_{0.1} \mathrm{AlSi}_{2} \mathrm{O}_{6}$ pollucite samples. 
Table 2. Diffraction intensities for selected planes in $\mathrm{CsAlSi}_{2} \mathrm{O}_{6}$ and $\mathrm{CsAlSi}_{2} \mathrm{O}_{6} \cdot \mathrm{nH}_{2} \mathrm{O}$.

\begin{tabular}{ccccc}
\hline \hline Composition & PDF\# (RDB) & $2 \theta$ & $($ h k l) & Intensity \\
\hline & & 24.299 & $\left(\begin{array}{lll}3 & 2 & 1\end{array}\right)$ & 50 \\
$\mathrm{CsAlSi}_{2} \mathrm{O}_{6}$ & $029-0407$ & 26.033 & $\left(\begin{array}{lll}4 & 0 & 0\end{array}\right)$ & 100 \\
& & 30.656 & $\left(\begin{array}{lll}3 & 3 & 2\end{array}\right)$ & 45 \\
& & 24.367 & $\left(\begin{array}{lll}3 & 2 & 1\end{array}\right)$ & 30 \\
$\mathrm{CsAlSi}_{2} \mathrm{O}_{6} \cdot \mathrm{nH}_{2} \mathrm{O}$ & $025-0194$ & 26.033 & $\left(\begin{array}{lll}4 & 0 & 0\end{array}\right)$ & 100 \\
& & 30.667 & $\left(\begin{array}{llll}3 & 3 & 2\end{array}\right)$ & 45 \\
\hline \hline
\end{tabular}

Data from PDF-4+ 2011 RDB

$\mathrm{Cs}_{0.9} \mathrm{Ba}_{0.1} \mathrm{AlSi}_{2} \mathrm{O}_{6}$ pollucite samples are shown in Fig. 10. The major crystalline phase of all the three samples matches the diffraction pattern of pollucite structure. The 5 at.\% and 10 at.\% Ba-doped pollucite samples also exhibit minor crystalline phases, as shown in Fig. 10, including possible $\mathrm{Si} / \mathrm{Al}$ oxides and $\mathrm{Ba}$ compounds. Natural pollucite usually contains water $\left(\mathrm{CsAlSi}_{2} \mathrm{O}_{6} \cdot \mathrm{nH}_{2} \mathrm{O}\right)$ and its diffraction pattern has different relative intensities compared to dry pollucite. Table 2 lists three strongest reflection intensities for $\mathrm{CsAlSi}_{2} \mathrm{O}_{6}$ (PDF\# 029-0407) and $\mathrm{CsAlSi}_{2} \mathrm{O}_{6} \cdot \mathrm{nH}_{2} \mathrm{O}$ (PDF\# 025-0194), as obtained from the Powder Diffraction File PDF-4+ 2011 RDB, provided by the International Centre for Diffraction Data (ICDD). As indicated in Table 2, the relative reflection intensity from (321) is stronger for $\mathrm{CsAlSi}_{2} \mathrm{O}_{6}(50 \%)$ than for $\mathrm{CsAlSi}_{2} \mathrm{O}_{6} \cdot \mathrm{nH}_{2} \mathrm{O}(30 \%)$. Although the $2 \theta$ values are slightly different, the two types of pollucite can be readily identified because both have $100 \%$ peaks at (400) and $45 \%$ peaks at (332). Clearly, for pollucite without water, the reflection intensity from (321) is larger than from (332). From Table 2, the data in Fig. 10 suggest that all the three samples do not contain water. This result is not a big surprise because the study samples were sintered at a high temperature $(1773 \mathrm{~K})$. It also indicates that the sintered pollucite (undoped and Ba-doped) does not absorb water and diffuses into the bulk under ambient conditions for an extended time (about a year).

\subsubsection{Composition}

The composition of the sintered pollucite samples has been analyzed using EDS integral to an EPMA. Figure 11 shows the EDS spectra for $\mathrm{CsAlSi}_{2} \mathrm{O}_{6}, \mathrm{Cs}_{0.9} \mathrm{Ba}_{0.05} \mathrm{AlSi}_{2} \mathrm{O}_{6}$ and $\mathrm{Cs}_{0.9} \mathrm{Ba}_{0.1} \mathrm{AlSi}_{2} \mathrm{O}_{6}$ pollucite samples with the elements indicated. $\mathrm{C}$ peak is from the surface coating for conductivity and is not from the sample. $\mathrm{O}, \mathrm{Al}$ and $\mathrm{Si}$ x-ray peaks are well resolved, but the multiple $\mathrm{Cs}$ and Ba peaks are overlapping. The analytical result from Fig. 11 is given in Table 3. The results are not expected to be very accurate, not only because the peaks are overlapping but also exact ZAF (atomic number, x-ray absorption and
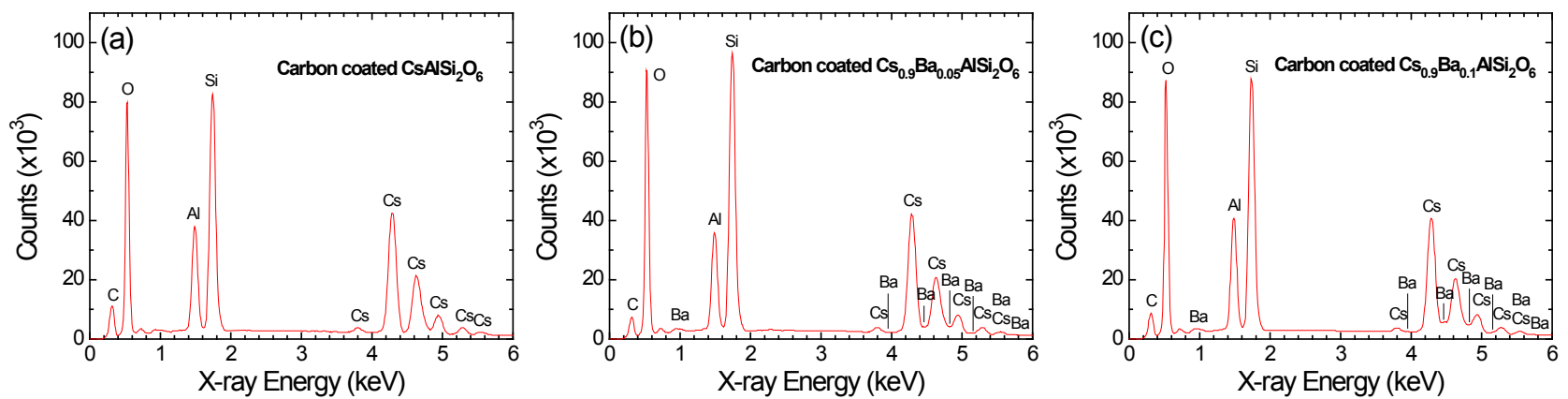

Figure 11. EDS spectra for C-coated (a) $\mathrm{CsAlSi}_{2} \mathrm{O}_{6}$, (b) $\mathrm{Cs}_{0.9} \mathrm{Ba}_{0.05} \mathrm{AlSi}_{2} \mathrm{O}_{6}$, and (c) $\mathrm{Cs}_{0.9} \mathrm{Ba}_{0.1} \mathrm{AlSi}_{2} \mathrm{O}_{6}$ pollucite. 
Table 3. Elemental percentage in $\mathrm{CsAlSi}_{2} \mathrm{O}_{6}, \mathrm{Cs}_{0.9} \mathrm{Ba}_{0.05} \mathrm{AlSi}_{2} \mathrm{O}_{6}$ and $\mathrm{Cs}_{0.9} \mathrm{Ba}_{0.1} \mathrm{AlSi}_{2} \mathrm{O}_{6}$ pollucite determined by EDS.

\begin{tabular}{|c|c|c|c|c|c|c|c|}
\hline \multicolumn{2}{|c|}{ Element } & $\mathrm{ms} \%$ & $\mathrm{~mol} \%$ & Sigma & Net & $\mathrm{K}$ ratio & Line \\
\hline 0 & $\mathrm{O}$ & 34.16 & 63.56 & 0.02 & 13414122 & 0.2680924 & $\mathrm{~K}$ \\
\hline$\frac{D}{\infty}$ & $\mathrm{Al}$ & 7.71 & 8.51 & 0.01 & 9697446 & 0.0379486 & $\mathrm{~K}$ \\
\hline م. & $\mathrm{Si}$ & 17.83 & 18.90 & 0.02 & 24244085 & 0.1028968 & $\mathrm{~K}$ \\
\hline & $\mathrm{Cs}$ & 40.30 & 9.03 & 0.03 & 36847680 & 0.3329303 & $\mathrm{~L}$ \\
\hline \multirow{6}{*}{ 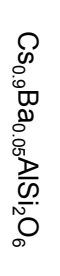 } & $\mathrm{O}$ & 35.44 & 64.69 & 0.02 & 15189022 & 0.3045886 & $\mathrm{~K}$ \\
\hline & $\mathrm{Al}$ & 6.58 & 7.12 & 0.01 & 9076160 & 0.0356371 & $\mathrm{~K}$ \\
\hline & $\mathrm{Si}$ & 18.86 & 19.61 & 0.02 & 28387572 & 0.1208887 & $\mathrm{~K}$ \\
\hline & $\mathrm{Cs}$ & 36.54 & 8.03 & 0.03 & 36436154 & 0.3303219 & $\mathrm{~L}$ \\
\hline & $\mathrm{Ba}$ & 2.58 & 0.55 & 0.03 & 1838428 & 0.0236385 & $\mathrm{~L}$ \\
\hline & $\mathrm{O}$ & 33.77 & 63.27 & 0.02 & 14095527 & 0.2826605 & $\mathrm{~K}$ \\
\hline \multirow{4}{*}{ 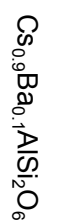 } & $\mathrm{Al}$ & 7.82 & 8.68 & 0.01 & 10436706 & 0.0409792 & $\mathrm{~K}$ \\
\hline & $\mathrm{Si}$ & 17.72 & 18.91 & 0.02 & 25570422 & 0.1088919 & $\mathrm{~K}$ \\
\hline & Cs & 36.06 & 8.13 & 0.03 & 35145455 & 0.3186207 & $\mathrm{~L}$ \\
\hline & $\mathrm{Ba}$ & 4.63 & 1.01 & 0.03 & 3221780 & 0.0414257 & $\mathrm{~L}$ \\
\hline
\end{tabular}

fluorescence) correction is not feasible. The large excitation volume near the surface induced by $20 \mathrm{keV}$ electrons used in the measurement could also contribute to uncertainty. In spite of those, an estimation of the main composition is possible. The data in Table 3 suggests that the composition in the three samples is nearly stoichiometric with a slightly higher concentration of oxygen (over 60 at.\% O).

More accurate chemical analysis based on ICP-AES also has been performed at SNL for all the possible elements in $\mathrm{CsAlSi}_{2} \mathrm{O}_{6}$ and $\mathrm{Cs}_{0.9} \mathrm{Ba}_{0.05} \mathrm{AlSi}_{2} \mathrm{O}_{6}$ and the results are given in Table 4. Based on the average weight ratio of the original data, elemental ratio was estimated, which is referenced to Cs. The composition in the two samples is confirmed to be nearly stoichiometric, only with a slight enrichment of $\mathrm{Si}\left(2\right.$ vs. 2.4 in $\mathrm{CsAlSi}_{2} \mathrm{O}_{6}$ and 2.5 in $\left.\mathrm{Cs}_{0.9} \mathrm{Ba}_{0.05} \mathrm{AlSi}_{2} \mathrm{O}_{6}\right)$.

As a complementary technique, non-destructive conventional $2.0 \mathrm{MeV} \mathrm{He}{ }^{+}$ion $\mathrm{RBS}$ combined with simulations of the experimental spectra using code SIMNRA (simulation of nuclear reaction analysis) have also been performed for confirmation of composition. The data for $\mathrm{CsAlSi}_{2} \mathrm{O}_{6}, \mathrm{Cs}_{0.9} \mathrm{Ba}_{0.05} \mathrm{AlSi}_{2} \mathrm{O}_{6}$
Table 4. Elemental ratio in undoped and Ba-doped pollucite determined by ICP-AES.

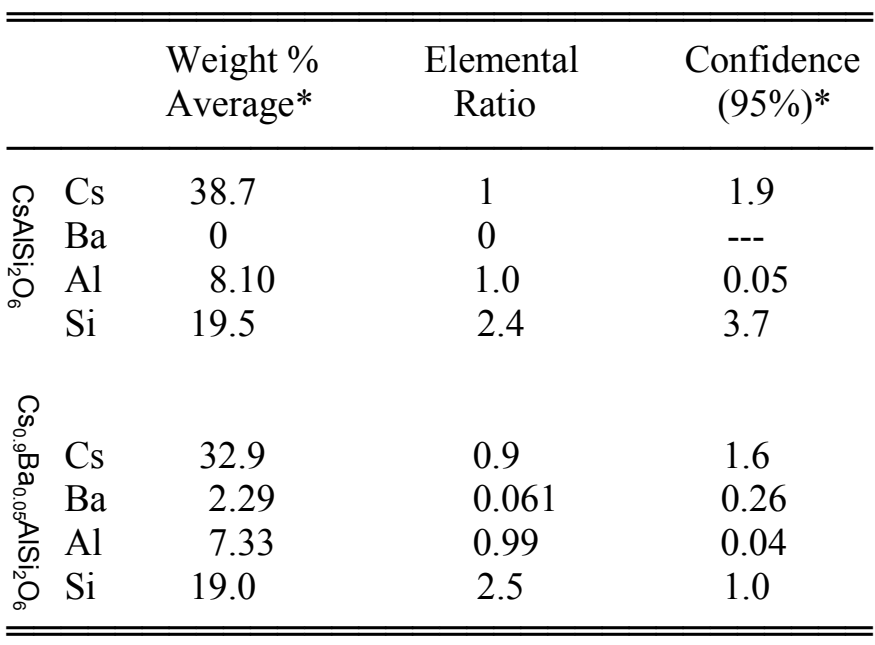

* Data from Sandia National Labs. 


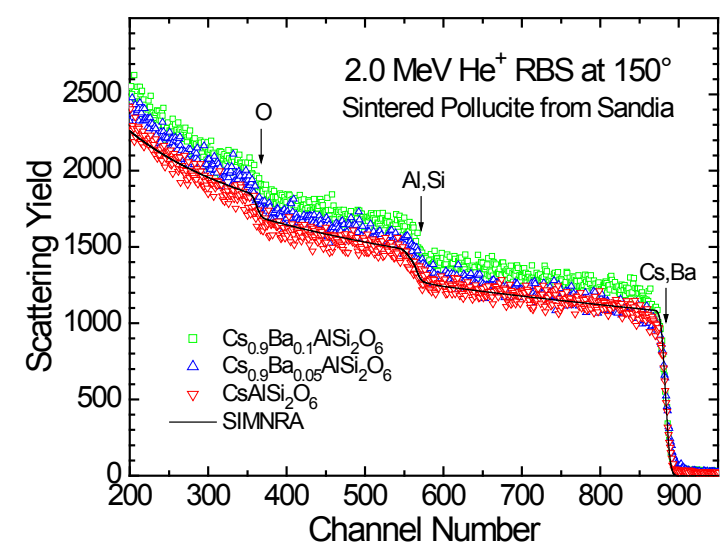

Figure 12. 2.0 $\mathrm{MeV} \mathrm{He}^{+}$ion RBS spectra for undoped and Ba-doped pollucite samples. Also included is the simulation result for $\mathrm{CsAlSi}_{2} \mathrm{O}_{6}$ from code SIMNRA.

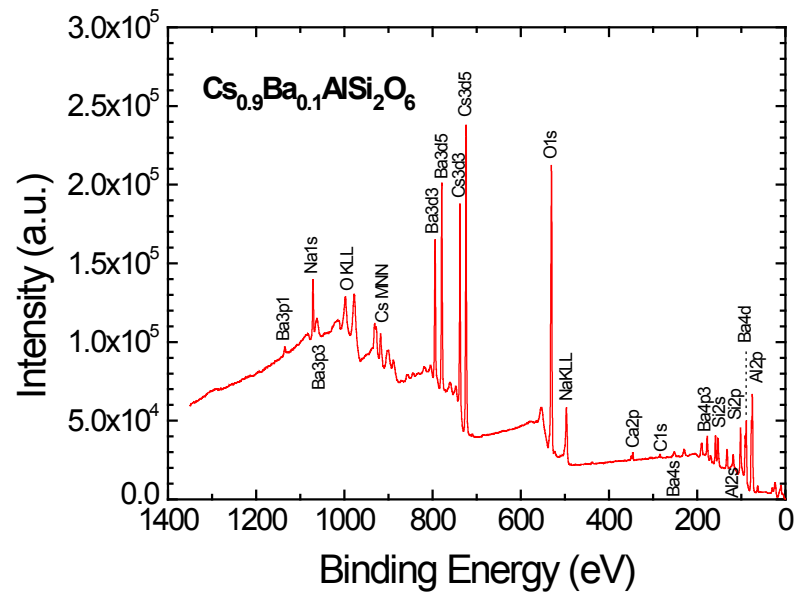

Figure 13. Survey XPS spectrum for as-sintered $\mathrm{Cs}_{0.9} \mathrm{Ba}_{0.1} \mathrm{AlSi}_{2} \mathrm{O}_{6}$

and $\mathrm{Cs}_{0.9} \mathrm{Ba}_{0.1} \mathrm{AlSi}_{2} \mathrm{O}_{6}$ pollucite samples are shown in Fig. 12. In the RBS spectra, Cs and $\mathrm{Ba}$ as well as $\mathrm{Al}$ and $\mathrm{Si}$ are not resolved, as expected, because of the limited mass resolution of RBS for heavy and medium-heavy elements. Energy spectra for $\mathrm{O}$ are identifiable. In the SIMNRA simulation (black solid line in Fig. 12) of the $\mathrm{CsAlSi}_{2} \mathrm{O}_{6}$ spectrum (red down triangle), the atomic percentages of the elements are assumed to be $10 \mathrm{Cs} \%, 10 \mathrm{Al} \%, 20 \mathrm{Si} \%$ and $60 \mathrm{O} \%$. Although the match between the simulation and the experiment is not perfect and fine adjustments in the composition can be made to improve the match, the overall composition of the sample is correct. All the spectra were collected under the same conditions with the same integrated charge $(10 \mu \mathrm{C})$. From Fig. 12, apparently, backscattering yield increases with increasing $\mathrm{Ba}$ concentration in the samples. This is because coulomb scattering cross section is directly proportional to the square of atomic number $\left(Z^{2}\right)$.

In addition, surface analysis was also performed using XPS without prior sputtering of the sample surface and the data for $\mathrm{Cs}_{0.9} \mathrm{Ba}_{0.1} \mathrm{AlSi}_{2} \mathrm{O}_{6}$ is shown in Fig. 13. We have found that quantitative analysis of elemental concentrations in the sintered samples is not highly reproducible probably due to the XPS nature of extreme surface sensitivity. Surface contamination could alter the results significantly. However, it is possible to use XPS to identify impurities of heavy elements that is not likely from the surface contamination. From the survey spectrum in Fig. 13, small amount of $\mathrm{Na}$ and $\mathrm{Ca}$ as impurities are identified in the sample.

\subsubsection{Elemental map}

Mapping of elements in undoped and Ba-doped pollucite has been performed using EPMA. Beam scans were conducted over $6 \times 6 \mu \mathrm{m}^{2}$ with spot size of $60 \times 60 \mathrm{~nm}^{2}$ and dwell time of $200 \mathrm{~ms}$ at each spot. Both EDS and WDS methods for elemental mapping were applied simultaneously for a direct comparison. In general, EDS has a higher yield and better statistics while WDS has a better elemental resolution. Figure 14 shows $\mathrm{Cs}$ and $\mathrm{Ba}$ maps from an area on an as-sintered $\mathrm{CsAlSi}_{2} \mathrm{O}_{6}$ sample. It is known that $\mathrm{Ba}$ concentration is negligible in the undoped sample, as determined by ICP-AES (Table 4). From EDS maps, the Ba concentration profile closely follows that of $\mathrm{Cs}$; at a grain boundary where there is a lack of $\mathrm{Cs}, \mathrm{Ba}$ also shows a lower concentration. This result is not due to the variation of $\mathrm{Ba}$ concentration, but due to overlap of $\mathrm{Ba}$ and $\mathrm{Cs}$ spectra, as shown in Fig. 11. The tails of the Cs peaks extend to the energy 

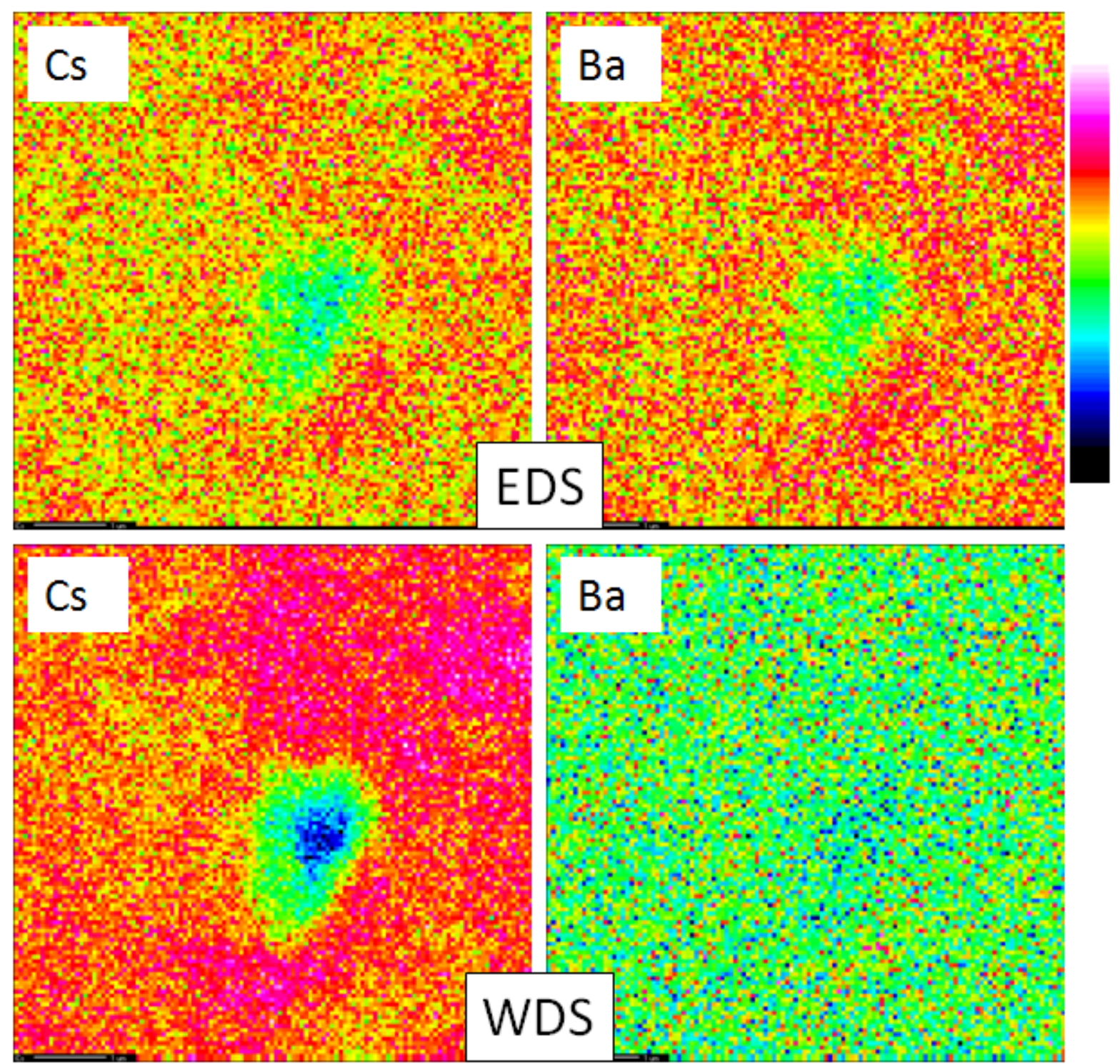

Figure 14. Comparison of EDS and WDS methods for mapping $\mathrm{Cs}$ and $\mathrm{Ba}$ in as-sintered $\mathrm{CsAlSi}_{2} \mathrm{O}_{6}$ (field of view: $6 \mu \mathrm{m}$ ).

region of $\mathrm{Ba}$ peaks and were taken as contributions from $\mathrm{Ba}$. In contrast, the WDS map for Ba shows a uniform background in the same area of Cs deficiency because of the better resolution of the $\mathrm{Ba}$ and $\mathrm{Cs}$ peaks. The data in Fig. 14 suggest that WDS method is more accurate than EDS in mapping Ba in the presence of high-concentration Cs. We collected both WDS and EDS mapping data for the three representative samples, but only show the WDS maps for the essential constituents of the samples.

Figures 15 through 17 show maps of $\mathrm{Cs}, \mathrm{Ba}, \mathrm{Al}, \mathrm{Si}$ and $\mathrm{O}$ in $\mathrm{CsAlSi}_{2} \mathrm{O}_{6}, \mathrm{Cs}_{0.9} \mathrm{Ba}_{0.05} \mathrm{AlSi}_{2} \mathrm{O}_{6}$ and $\mathrm{Cs}_{0.9} \mathrm{Ba}_{0.1} \mathrm{AlSi}_{2} \mathrm{O}_{6}$ pollucite samples, respectively. Backscattering electron (BSE) image prior to scans for mapping is also included in each figure, which shows $\mathrm{Z}$ contrast. It has been observed that the contrast in the BSE image becomes darker after the scan, probably due to amorphization of the material followed by Cs loss (see below). With increasing dwell time, darker BSE image in the scanned area was observed. In Fig. 15 for $\mathrm{CsAlSi}_{2} \mathrm{O}_{6}$, there is a lower Cs concentration on the left of the map, while in the same region $\mathrm{Al}, \mathrm{Si}$ and $\mathrm{O}$ are relatively enriched. The data may suggest presence of aluminum and/or silicon oxides or 
Cs-deficient aluminosilicate pollucite. At a grain boundary (lower middle) where the BSE image shows darker contrast, Cs appears to be enriched with little Al, Si and O concentrations. Although BSE image does not include morphologic information in principle, some hillocks on the surface could block backscattering electrons from entering the detector, making the nearby valley darker in contrast. The brighter area close to the center of the BSE image corresponds to a higher Cs concentration shown in the Cs map, as expected. In the 5\% Ba-doped pollucite (Fig. 16), Cs deficiency coupled with enrichment of $\mathrm{Al}, \mathrm{Si}$ and $\mathrm{O}$ is observed on the left. The brighter areas shown in the BSE image correspond to denser Cs regions. The distribution of doped $\mathrm{Ba}$ is not uniform and there is clear evidence for $\mathrm{Ba}$ aggregation in local areas (also see below). Fig. 16 suggests that the Ba concentration is lower in the area where the Cs is enriched, e.g., in the lower middle to right region. When the Ba doping concentration increases to 10 at.\%, the brightest areas in the BSE image correspond to Ba-aggregated regions where the $\mathrm{Cs}$ and $\mathrm{Al}$ have a lower concentration, as shown in Fig. 17. The data in Fig. 17 also suggest that where there is an enrichment of $\mathrm{Cs}$, there is a deficiency of $\mathrm{Ba}$, which is also indicated in Fig. 16 for $\mathrm{Cs}_{0.9} \mathrm{Ba}_{0.05} \mathrm{AlSi}_{2} \mathrm{O}_{6}$. It should be noted that since $20 \mathrm{keV}$ electrons were used for the elemental mapping, the excitation volume is relatively large and the elemental concentrations on the maps in Figs. 15 through 17 are measured from the total volume near the surface.
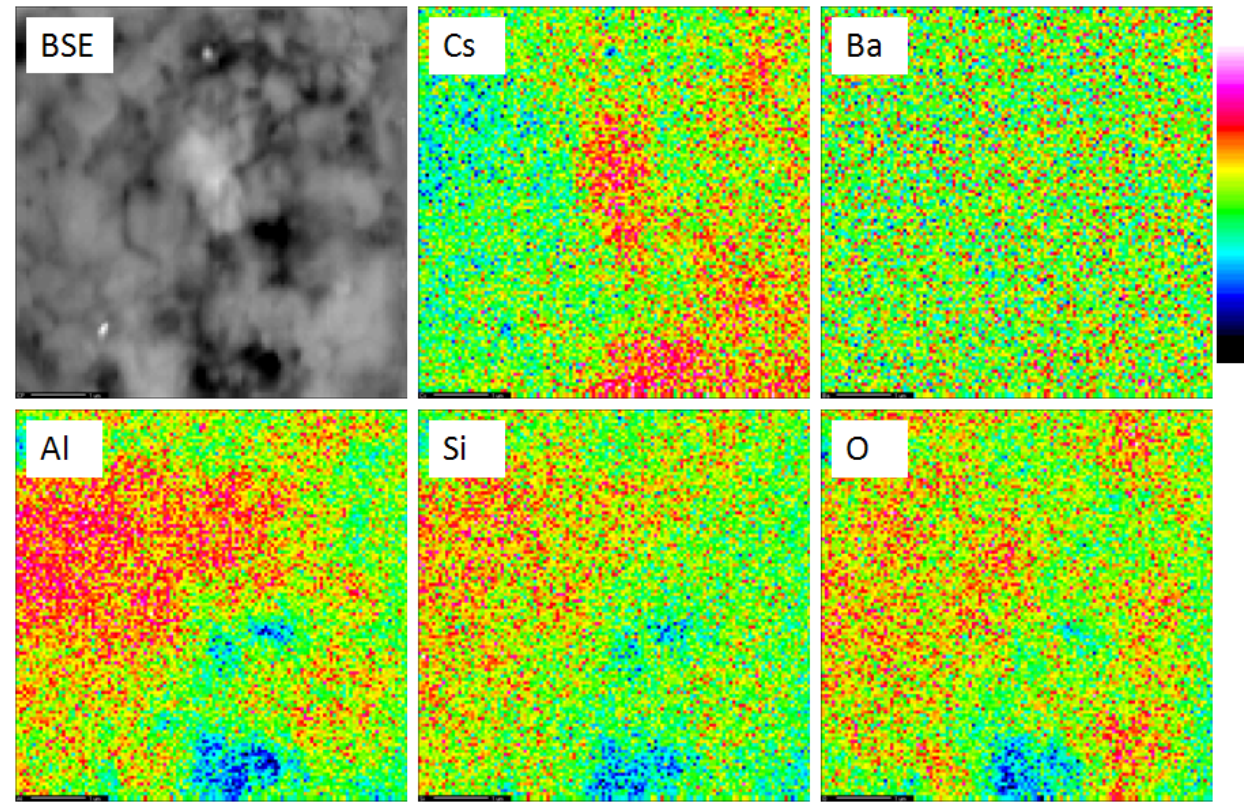

Figure 15. Backscattering electron image and WDS elemental maps of C-coated $\mathrm{CsAlSi}_{2} \mathrm{O}_{6}$ (field of view: $6 \mu \mathrm{m}$ ). 

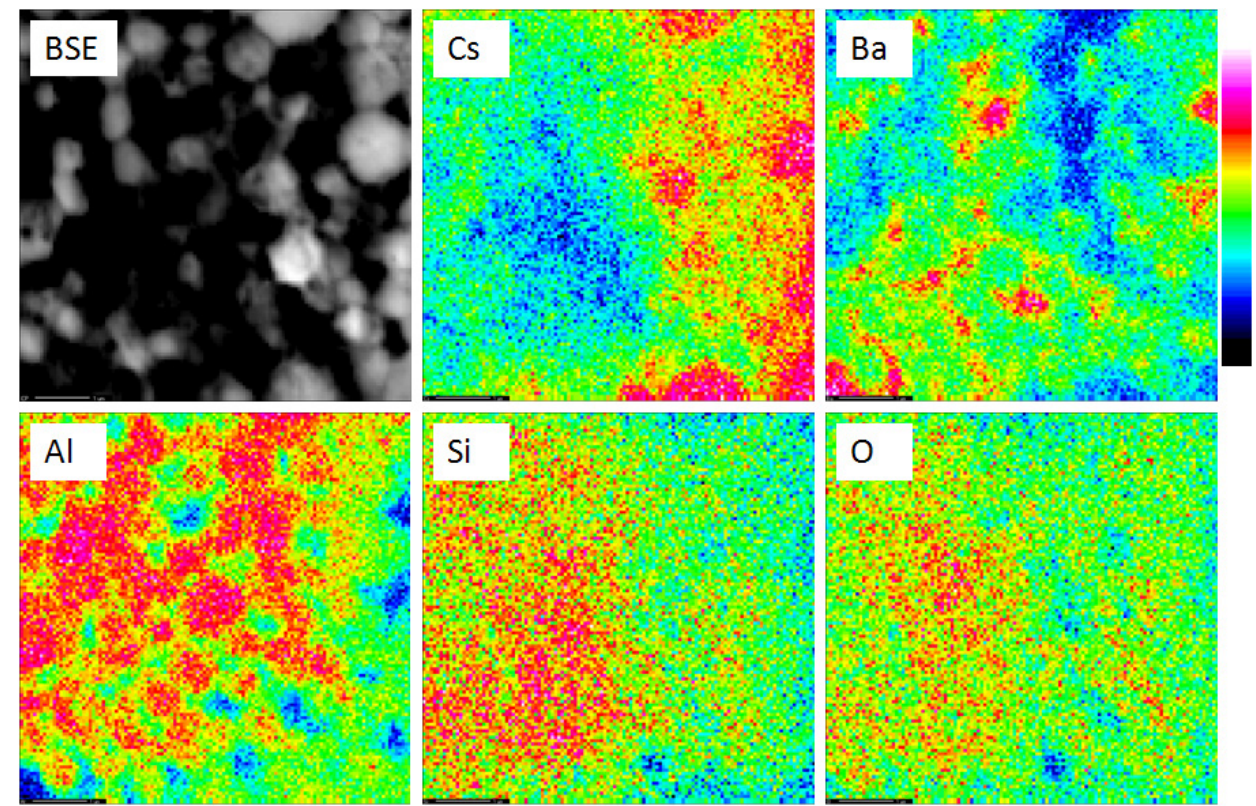

Figure 16. Backscattering electron image and WDS elemental maps of C-coated $\mathrm{Cs}_{0.9} \mathrm{Ba}_{0.05} \mathrm{AlSi}_{2} \mathrm{O}_{6}$ (field of view: $6 \mu \mathrm{m}$ ).
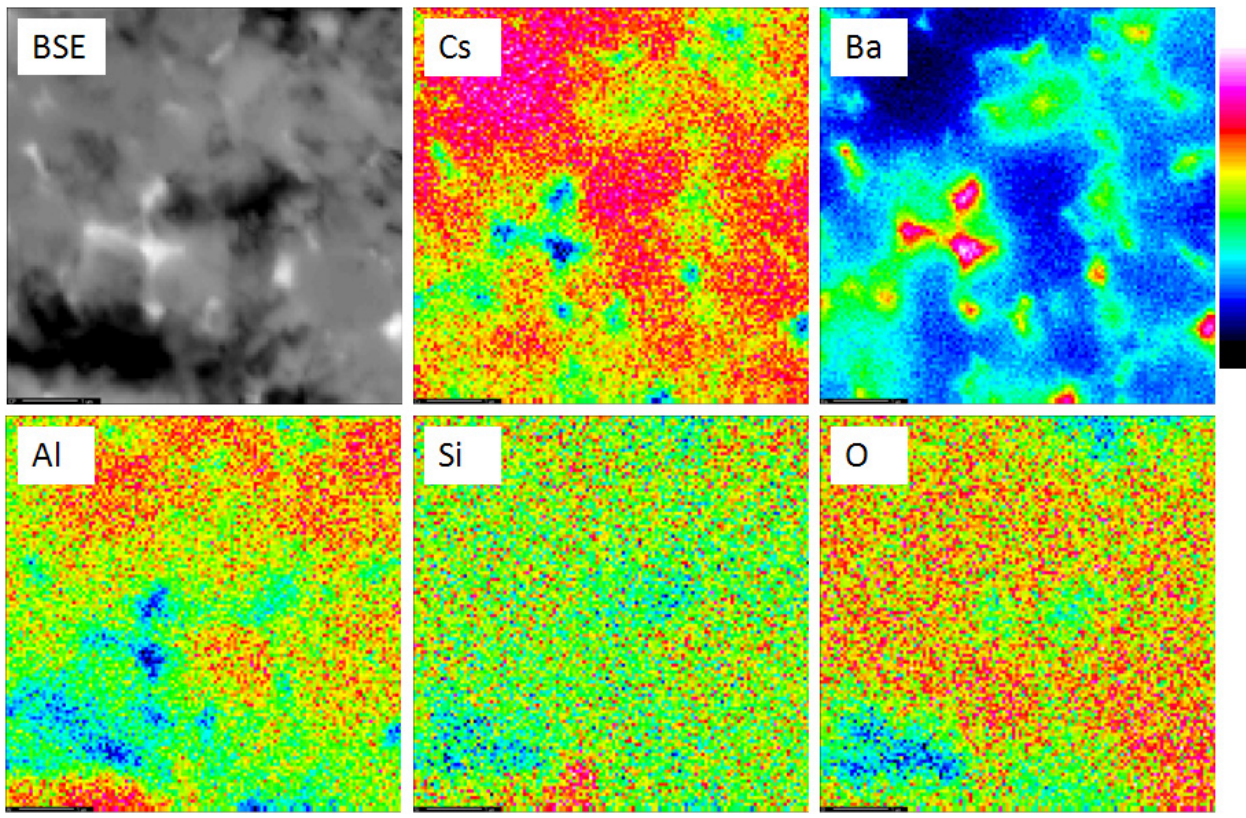

Figure 17. Backscattering electron image and WDS elemental maps of C-coated $\mathrm{Cs}_{0.9} \mathrm{Ba}_{0.1} \mathrm{AlSi}_{2} \mathrm{O}_{6}$ (field of view: $6 \mu \mathrm{m}$ ). 


\subsubsection{Microstructure}

The undoped and Ba-doped pollucite samples were examined using HIM. Figure 18 shows the freshly cleaved cross sections of the three representative samples with a field of view (FOV) of $10 \mu \mathrm{m}$. No carbon or other conductive coatings were applied onto the sample surface. The imaging $\mathrm{He}^{+}$beam had energy of 25 or $30 \mathrm{keV}$ with a typical current intensities ranging from 6 to $12 \mathrm{pA}$. All the samples are good insulators and charging effects are significant during imaging under the applied FOV. Compensation of the surface positive charge was achieved using an electron flood gun integral to the HIM system. The beam-induced damage at the sample surface was minimal in all cases. Interconnected crystallites of $\mathrm{CsAlSi}_{2} \mathrm{O}_{6}$ with sizes ranging from $100 \mathrm{~nm}$ to $1 \mu \mathrm{m}$ are observed as shown in Fig. 18(a). Apparent facets of the crystallites appear. For $\mathrm{Cs}_{0.9} \mathrm{Ba}_{0.05} \mathrm{AlSi}_{2} \mathrm{O}_{6}$ shown in Fig. 18(b), the average crystallite size is a little larger and material density higher as compared to the undoped pollucite. It was quite evident that the surface charging on the sample was more severe and a complete charge compensation was not possible under the FOV. Consequently, the crystallite facets are hardly visible due to charging induced deterioration in beam focusing. With increasing doping concentration of $\mathrm{Ba}$ to 10 at.\%, the material becomes even denser and the crystallites even larger, as shown in Fig. 18(c). Some small particles with brighter contrast located at the grain boundaries are observed. Those are Ba-containing aggregates as also observed by TEM (see below). Although it may be of fundamental interest to further study the microstructure as a function of $\mathrm{Ba}$ concentration, it is not the focus of this report.
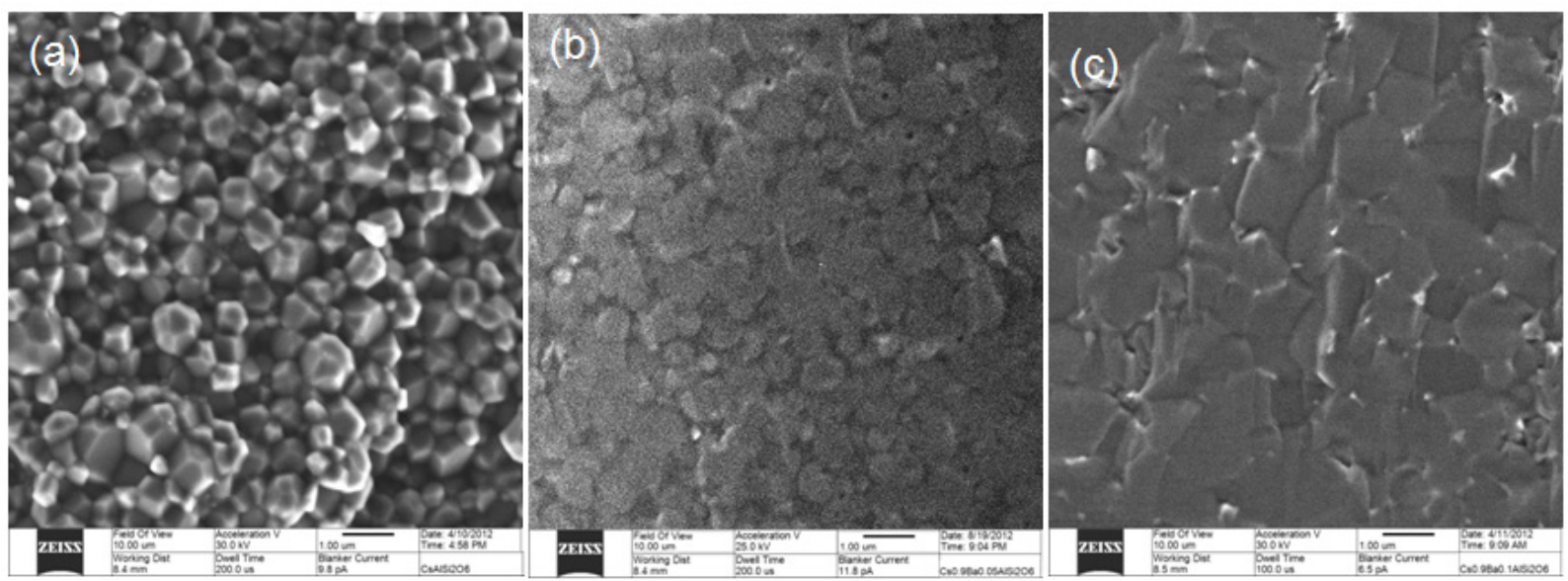

Figure 18. Cross-sectional HIM micrographs of as-sintered (a) $\mathrm{CsAlSi}_{2} \mathrm{O}_{6}$, (b) $\mathrm{Cs}_{0.9} \mathrm{Ba}_{0.05} \mathrm{AlSi}_{2} \mathrm{O}_{6}$, and (c) $\mathrm{Cs}_{0.9} \mathrm{Ba}_{0.1} \mathrm{AlSi}_{2} \mathrm{O}_{6}$ (field of view: $10 \mu \mathrm{m}$ ).

\subsection{Ion-Implanted Pollucite}

\subsubsection{Implantation damage and $F$ diffusion}

Implantation with both $\mathrm{F}^{+}$and $\mathrm{O}^{+}$ions was performed for Ba-doped pollucite samples to study possible charge mitigation effects. GIXRD was used to characterize the structure of the implantation layer at the surface. This experimental report focuses on the study of $\mathrm{F}^{+}$ion implanted samples. Figure 19 shows the GIXRD patterns for $\mathrm{Cs}_{0.9} \mathrm{Ba}_{0.05} \mathrm{AlSi}_{2} \mathrm{O}_{6}$ and $\mathrm{Cs}_{0.9} \mathrm{Ba}_{0.1} \mathrm{AlSi}_{2} \mathrm{O}_{6}$ before and after $\mathrm{F}^{+}$ion implantation and post annealing. $1.2 \mathrm{MeV} \mathrm{F}^{+}$ions were employed for the implantation at $673 \mathrm{~K}$ to an ion fluence of $8.2 \times 10^{16}$ $\mathrm{F}^{+} / \mathrm{cm}^{2}$, corresponding to an atomic concentration of 3 at. $\% \mathrm{~F}$ at the profile peak. Post thermal annealing was conducted at $1423 \mathrm{~K}$ for 10 hours in a flowing Ar gas environment. The two samples were implanted and annealed under the identical conditions. The asymmetric scans were conducted over the range of $2 \theta=$ 

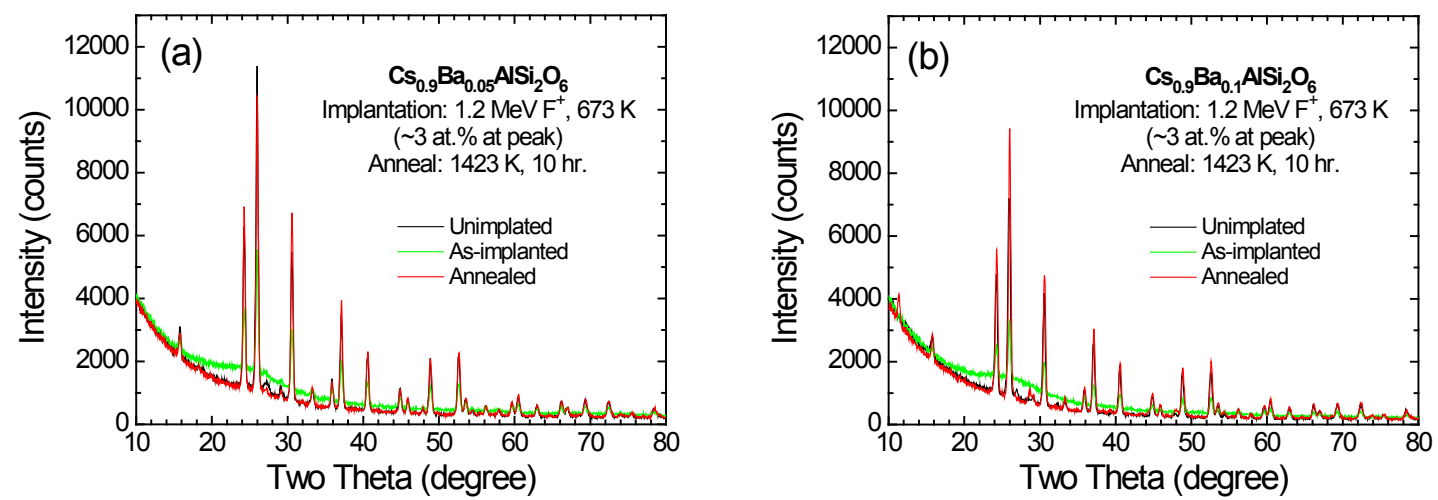

Figure 19. GIXRD patterns for (a) $\mathrm{Cs}_{0.9} \mathrm{Ba}_{0.05} \mathrm{AlSi}_{2} \mathrm{O}_{6}$ and (b) $\mathrm{Cs}_{0.9} \mathrm{Ba}_{0.1} \mathrm{AlSi}_{2} \mathrm{O}_{6}$ before and after $\mathrm{F}^{+}$ ion implantation at $673 \mathrm{~K}$ and thermal annealing at $1423 \mathrm{~K}$.

$10^{\circ}-80^{\circ}$ with $\omega=2^{\circ}$. Clearly, there is a highly disordered or amorphized layer in the as-implanted $\mathrm{Cs}_{0.9} \mathrm{Ba}_{0.05} \mathrm{AlSi}_{2} \mathrm{O}_{6}$, as indicated in Fig. 19(a) by a broad peak around $2 \theta=25^{\circ}$. The diffraction peaks with the same pattern but much lower intensities, originate from the pollucite crystal at larger depths beyond the implantation layer. The lattice disorder induced by $\mathrm{F}^{+}$ion implantation can be attributed to both atomic displacements from elastic collisions and to radiolysis from electronic energy deposition (see below). After the thermal annealing, the diffraction pattern matches well with the one for the unimplanted sample. The result suggests that nearly a complete recovery of the crystal structure occurred during the thermal annealing at $1423 \mathrm{~K}$. Similar behavior of the damage accumulation and recovery in $\mathrm{Cs}_{0.9} \mathrm{Ba}_{0.1} \mathrm{AlSi}_{2} \mathrm{O}_{6}$ is observed, as shown in Fig. 19(b).

The implanted and annealed $\mathrm{Cs}_{0.9} \mathrm{Ba}_{0.1} \mathrm{AlSi}_{2} \mathrm{O}_{6}$ pollucite samples were analyzed with SIMS and the data for the depth profiles of the implanted $\mathrm{F}$ are shown in Fig. 20. SIMS generally has a very high detection sensitivity and is designed for low-concentration measurements. As SIMS detection efficiency for F is extremely high, there is a saturation of signals around the F peak ( $\sim 3$ at.\%). The dashed green line is an extrapolation of the data to show the expected $F$ profile. Further measurements of $F$ using XPS are planned to confirm the depth profile. The presence of the well defined $F$ peak with a small concentration at the surface is an indication that $\mathrm{F}$ is largely immobile in the sintered pollucite during ion implantation at 673 K. Following thermal annealing at $1423 \mathrm{~K}$, fluorine concentration is reduced to the level in the unimplanted sample, as shown in Fig. 20. The $\mathrm{F}$ intensity is about 3 orders less in magnitude than that at the peak for the asimplanted sample. This behavior is likely to be associated with $\mathrm{F}$ out-diffusion and release from the sample surface. It should be mentioned that the F peak is located at the depth of $\sim 1.5 \mu \mathrm{m}$ and ends at $\sim 1.9 \mu \mathrm{m}$ (Fig. 20). This depth range is comparable to but slightly shallower than the

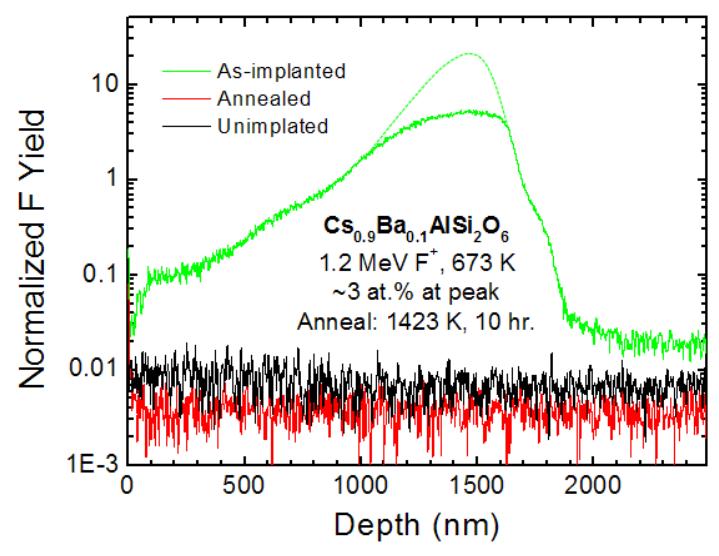

Figure 20. SIMS depth profiles of $F$ in $\mathrm{Cs}_{0.9} \mathrm{Ba}_{0.1} \mathrm{AlSi}_{2} \mathrm{O}_{6}$ before and after $\mathrm{F}^{+}$ion implantation and thermal annealing at $1423 \mathrm{~K}$. The dashed line is the data extrapolation (see text). 

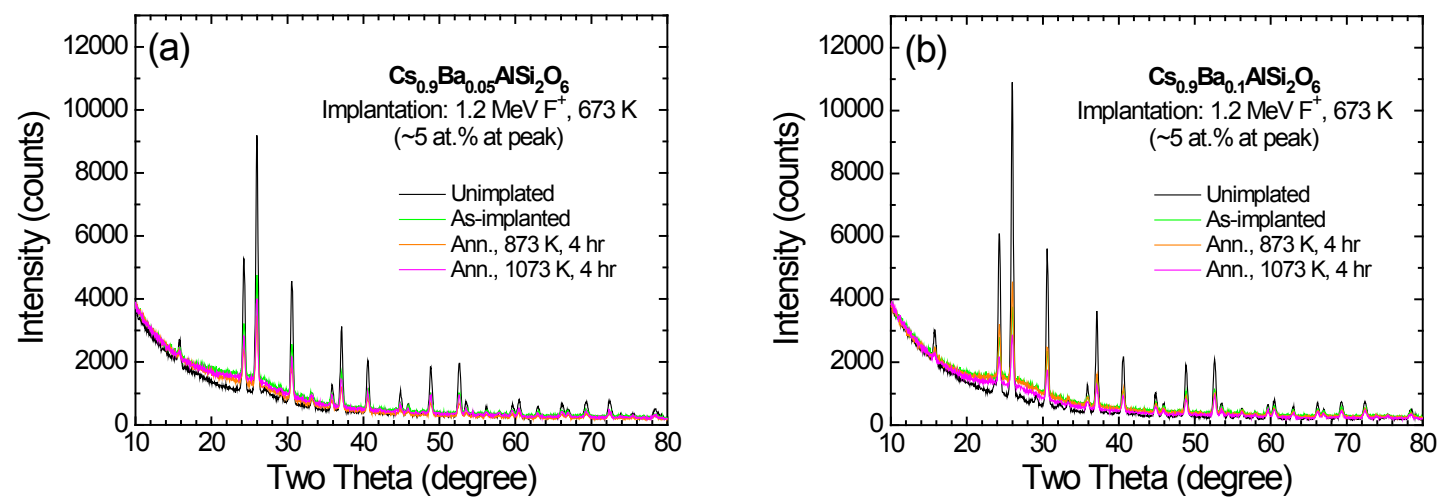

Figure 21. GIXRD patterns for (a) $\mathrm{Cs}_{0.9} \mathrm{Ba}_{0.05} \mathrm{AlSi}_{2} \mathrm{O}_{6}$ and (b) $\mathrm{Cs}_{0.9} \mathrm{Ba}_{0.1} \mathrm{AlSi}_{2} \mathrm{O}_{6}$ before and after $\mathrm{F}^{+}$ ion implantation at $673 \mathrm{~K}$ and thermal annealing at 873 and $1073 \mathrm{~K}$.

prediction (1.725 and $2.1 \mu \mathrm{m}$, respectively) by SRIM simulation (Fig. 4). It should be noted that the stopping powers in the SRIM database have been observed to be overestimated for slow ions in various materials. Thus, the peak depth is expected to be larger than predicted. The data in Fig. 20 suggest that F out-diffusion could occur at $673 \mathrm{~K}$ and/or the assumed overall specific gravity $\left(2.9 \mathrm{~g} / \mathrm{cm}^{3}\right)$ in the simulation is slightly larger than the actual value.

Another implantation of as-sintered samples with $1.2 \mathrm{MeV} \mathrm{F}^{+}$ions was conducted at $673 \mathrm{~K}$ to an ion fluence of $1.36 \times 10^{17} \mathrm{~F}^{+} / \mathrm{cm}^{2}$, corresponding to 5 at.\% $\mathrm{F}$ at the peak. Post thermal annealing was carried out at 873 and $1073 \mathrm{~K}$ for 4 hours each in flowing Ar environment. The same experimental methods (GIXRD and SIMS) were utilized to characterize the samples. Figure 21 shows the GIXRD patterns for the as-implanted and post annealed $\mathrm{Cs}_{0.9} \mathrm{Ba}_{0.05} \mathrm{AlSi}_{2} \mathrm{O}_{6}$ and $\mathrm{Cs}_{0.9} \mathrm{Ba}_{0.1} \mathrm{AlSi}_{2} \mathrm{O}_{6}$. For the as-implanted $\mathrm{Cs}_{0.9} \mathrm{Ba}_{0.05} \mathrm{AlSi}_{2} \mathrm{O}_{6}$, a similar broad peak appears, as shown in Fig. 21(a), which is again attributed to the disordered layer induced by ion implantation. The data is consistent with that shown in Fig. 19. Upon annealing at $873 \mathrm{~K}$, there is only a modest recovery of the implantation defects; further annealing at 1073 $\mathrm{K}$ results in additional, but still small recovery. The implantation induced lattice disorder is still largely present after the thermal annealing processes. For $\mathrm{Cs}_{0.9} \mathrm{Ba}_{0.1} \mathrm{AlSi}_{2} \mathrm{O}_{6}$, the results are similar, as shown in Fig. 21(b). Subsequent SIMS analysis was performed and the data are shown in Fig. 22. Again, SIMS signal saturates as a plateau near the $\mathrm{F}$ peak and the dashed lines are drawn to extrapolate the $\mathrm{F}$ profiles. For as-implanted $\mathrm{Cs}_{0.9} \mathrm{Ba}_{0.1} \mathrm{AlSi}_{2} \mathrm{O}_{6}, \mathrm{~F}$ shows a rather symmetric peak in the linear scale. After annealing at 873 $\mathrm{K}$, the shape becomes skewed toward the surface, indicating that there is out-diffusion of the implanted $\mathrm{F}$, but $\mathrm{F}$ loss is negligible at $873 \mathrm{~K}$ within 4 hours as its concentration at the surface is still small. A more significant $\mathrm{F}$ out-diffusion occurs at $1073 \mathrm{~K}$ and the $\mathrm{F}$ profile becomes much flatter with a relatively high concentration at the surface. As a result, considerable amount of $\mathrm{F}$ escapes from the sample. This behavior is consistent with the complete loss of $\mathrm{F}$ in the $1423 \mathrm{~K}$ annealed sample (Fig. 20). As will be

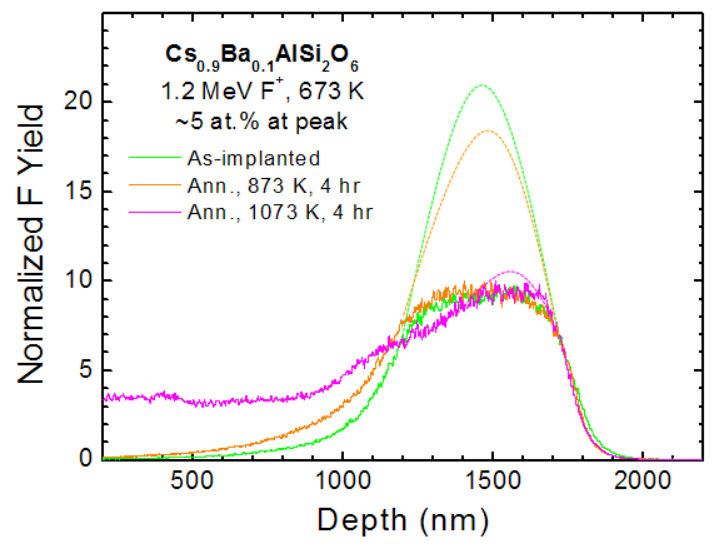

Figure 22. SIMS depth profiles of $F$ in $\mathrm{Cs}_{0.9} \mathrm{Ba}_{0.1} \mathrm{AlSi}_{2} \mathrm{O}_{6}$ after $\mathrm{F}^{+}$ion implantation and thermal annealing at 873 and $1073 \mathrm{~K}$. The dashed lines are the data extrapolation (see text). 
discussed below, the rather flat distribution of $\mathrm{F}$ over the surface region at $1073 \mathrm{~K}$ (Fig. 22) is an indication of $\mathrm{F}$ trapping at the structure by potentially forming chemical bonds with the excess $\mathrm{Ba}$. The $\mathrm{BaF}$ unit could decompose at $1423 \mathrm{~K}$, resulting in complete release of $\mathrm{F}$ at the high temperature.

\subsubsection{Bubble formation}

The microstructures of the $\mathrm{F}^{+}$ion-implanted and thermally annealed samples were examined using HIM. Figure 23 shows the cross sectional views of $\mathrm{Cs}_{0.9} \mathrm{Ba}_{0.05} \mathrm{AlSi}_{2} \mathrm{O}_{6}$ at different stages of the implantation and annealing. A damage layer at the surface is clearly visible in each case. In contrast to the grains at the larger depths beyond the damage layer, the implantation layer shows a smoother morphology without presence of grain boundaries, suggesting that the material is highly disordered or fully amorphized. Inside the layer, there are holes of various sizes up to $500 \mathrm{~nm}$. Those holes are attributed to $\mathrm{F}_{2}$ gas filled bubbles formed during ion implantation at an elevated temperature $(673 \mathrm{~K})$. Upon annealing at $873 \mathrm{~K}$ for 4 hours, bubbles grow to larger sizes and can internally interconnect themselves; some bubbles rupture at the surface and release the pressurized $\mathrm{F}_{2}$ gas, as can be seen from Fig. 23(b). With increasing temperature to $1073 \mathrm{~K}$, the average size of the bubble becomes larger, but the microstructure in the highly disordered or fully amorphized region shows little change. The layer thickness remains unchanged and recrystallization within the layer is not observed. The results shown in Fig. 23 are consistent with those in Fig. 21(a).

In sharp contrast to $\mathrm{Cs}_{0.9} \mathrm{Ba}_{0.05} \mathrm{AlSi}_{2} \mathrm{O}_{6}$, sample $\mathrm{Cs}_{0.9} \mathrm{Ba}_{0.1} \mathrm{AlSi}_{2} \mathrm{O}_{6}$ implanted and annealed under the same conditions shows very different behavior. There are no bubbles observed in the layer even after annealing at $1073 \mathrm{~K}$ for 4 hours, as shown in Fig. 24. In the unimplanted region, there are white spots, probably due to Ba-containing phases (see below). Within the damage layer, this contrast remains visible. There is no evidence showing recrystallization of the implantation layer after annealing at $1073 \mathrm{~K}$. While pollucite $\mathrm{Cs}_{0.9} \mathrm{Ba}_{0.05} \mathrm{AlSi}_{2} \mathrm{O}_{6}$ could be more charge balanced in the structure [Nenoff 2011], $\mathrm{Cs}_{0.9} \mathrm{Ba}_{0.1} \mathrm{AlSi}_{2} \mathrm{O}_{6}$ has extra $\mathrm{Ba}$ and may not be able to be accommodated in the pollucite structure. It is still unknown why $\mathrm{F}_{2}$ bubbles cannot be formed in the $\mathrm{Cs}_{0.9} \mathrm{Ba}_{0.1} \mathrm{AlSi}_{2} \mathrm{O}_{6}$ structure and weather it is associated with the presence of extra $\mathrm{Ba}$ that might form $\mathrm{BaF}$ as a unit, thus prohibiting formation of $\mathrm{F}_{2}$ bubbles. If $\mathrm{BaF}$ exists in the structure, the unit might be able to substitute Cs lattice in the wide channel (big pore of the zeolite structure (Fig. 1)) or even other sites as well. Further studies are needed to understand the behavior. Again from Fig. 24(a), the thickness of the implantation layer is $\sim 1.7 \mu \mathrm{m}$ and remains unchanged after annealing at temperatures up to $1073 \mathrm{~K}$. This thickness is slightly smaller than SRIM prediction of $\sim 2 \mu \mathrm{m}$, suggesting again that a slightly larger specific gravity of the material $\left(2.9 \mathrm{~g} / \mathrm{cm}^{3}\right)$ was used in the simulation. This is consistent with the observation of a shallower F depth profile in Figs. 20 and 22.

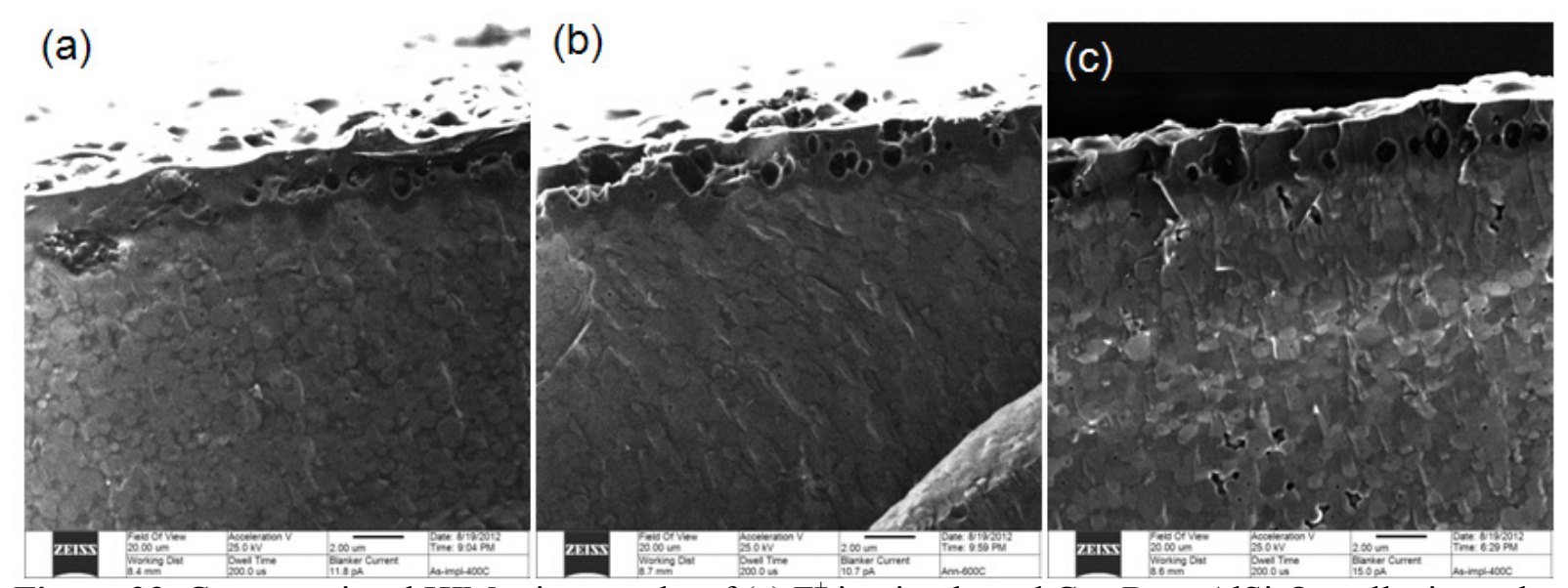

Figure 23. Cross-sectional HIM micrographs of (a) $\mathrm{F}^{+}$ion implanted $\mathrm{Cs}_{0.9} \mathrm{Ba}_{0.05} \mathrm{AlSi}_{2} \mathrm{O}_{6}$ pollucite and post annealed sample at (b) $873 \mathrm{~K}$ and (c) $1073 \mathrm{~K}$ (field of view: $20 \mu \mathrm{m}$ ). 
(a)

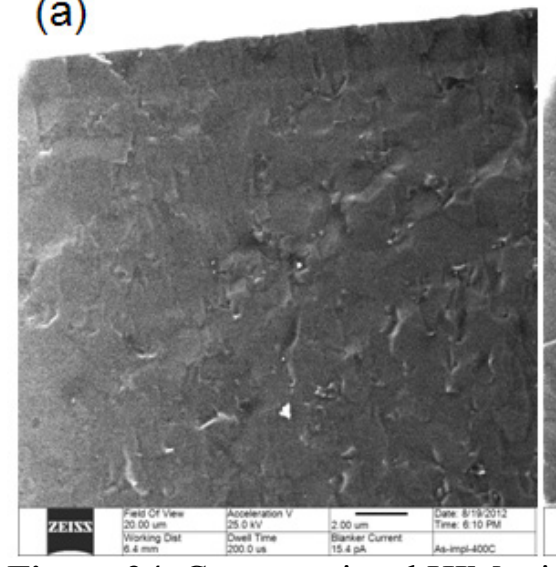

(b)

Figure 24. Cross-sectional HIM micrographs of (a) $\mathrm{F}^{+}$ion implanted $\mathrm{Cs}_{0.9} \mathrm{Ba}_{0.1} \mathrm{AlSi}_{2} \mathrm{O}_{6}$ pollucite and post annealed sample at (b) $873 \mathrm{~K}$ and (c) $1073 \mathrm{~K}$ (field of view: $20 \mu \mathrm{m}$ ).

\subsubsection{Atomic arrangements of pollucite and Ba-containing precipitates}

Figure 25 (a) shows a low-resolution high-angle annular dark-field (HAADF) TEM micrograph of $\mathrm{F}^{+}$ion implanted and $1073 \mathrm{~K}$ annealed $\mathrm{Cs}_{0.9} \mathrm{Ba}_{0.1} \mathrm{AlSi}_{2} \mathrm{O}_{6}$ pollucite. Selected area electron diffraction (data not shown) inside the surface implantation layer indicates that the layer of $\sim 1.7 \mu \mathrm{m}$ in thickness beneath the protective/conductive coating layer is completely amorphized. Beyond the amorphization layer is the unaffected area showing clear grains. At the grain boundaries, the contrast is brighter, indicating aggregation of heavier elements, as also shown in Fig. 25 (b) for a magnified view. The white area surrounding the sample is due to larger thickness where more electrons are scattered into the high-angle detector. In Fig. 25(b), it was evident that the pollucite material was amorphized due to $300 \mathrm{keV}$ electron irradiation during alignment of the crystal zone axis to the electron beam. Even for a short-time scan for taking data, a darker spot is clearly visible, indicating lattice damage. The electron irradiation induced amorphization is also demonstrated in a magnified view in Fig. 25(c), which shows two amorphization spots induced by the electron irradiation. Similar behavior was also reported for ${ }^{137} \mathrm{Cs}$ containing pollucite under TEM examination using $200 \mathrm{keV}$ electrons [Strachan 1997]. Since the maximum energy imparted to the lattice atoms by either 200 or $300 \mathrm{keV}$ electrons upon elastic collision is expected to be well below the threshold displacement energy (on the order of $10-100 \mathrm{eV}$ ) for any sublattices in $\mathrm{CsAlSi}_{2} \mathrm{O}_{6}$, atomic displacements are not the possible route for accumulation-induced amorphization. Instead, the amorphization is mainly attributed to ionization-induced radiolysis due to electronic energy deposition from the intense electron beam. The precipitates (area 2 in Fig. 25(b)) as well as the darker area (area 1) were analyzed using EDS, as shown in Fig. 25(d). The results show that the darker area is pure $\mathrm{CsAlSi}_{2} \mathrm{O}_{6}$ pollucite without $\mathrm{Ba}$ incorporation, whereas the precipitate consists of mainly $\mathrm{Ba}, \mathrm{Si}$ and $\mathrm{O}$.

The pure pollucite structure in the unimplanted area about $\sim 1.3 \mu \mathrm{m}$ away from the crystalline/amorphous interface, as shown in Fig. 25(b), was examined and the HAADF atomic-level resolution TEM micrograph is shown in Fig. 26(a). The Cs atoms in the crystal structure are clearly exhibited as bright spots. Due to a significant contrast, $\mathrm{Si}$ and $\mathrm{Al}$ lattices are not visible. A simulated atomic arrangement of Cs in the cubic pollucite on the (111) projection is illustrated in Fig. 26(b), which exactly matches the observed Cs lattice in Fig. 26(a). The red triangles in both panels connect the three nearest Cs atoms in wide channels for a better comparison. From Fig. 26(a), the Cs atoms located in wide channels are brighter, corresponding to a higher electron scattering yield received by the high-angle detector. This is mainly because the atomic column has a larger Cs occupancy, as illustrated by the $3 \mathrm{D}$ view in Fig. 1. In 

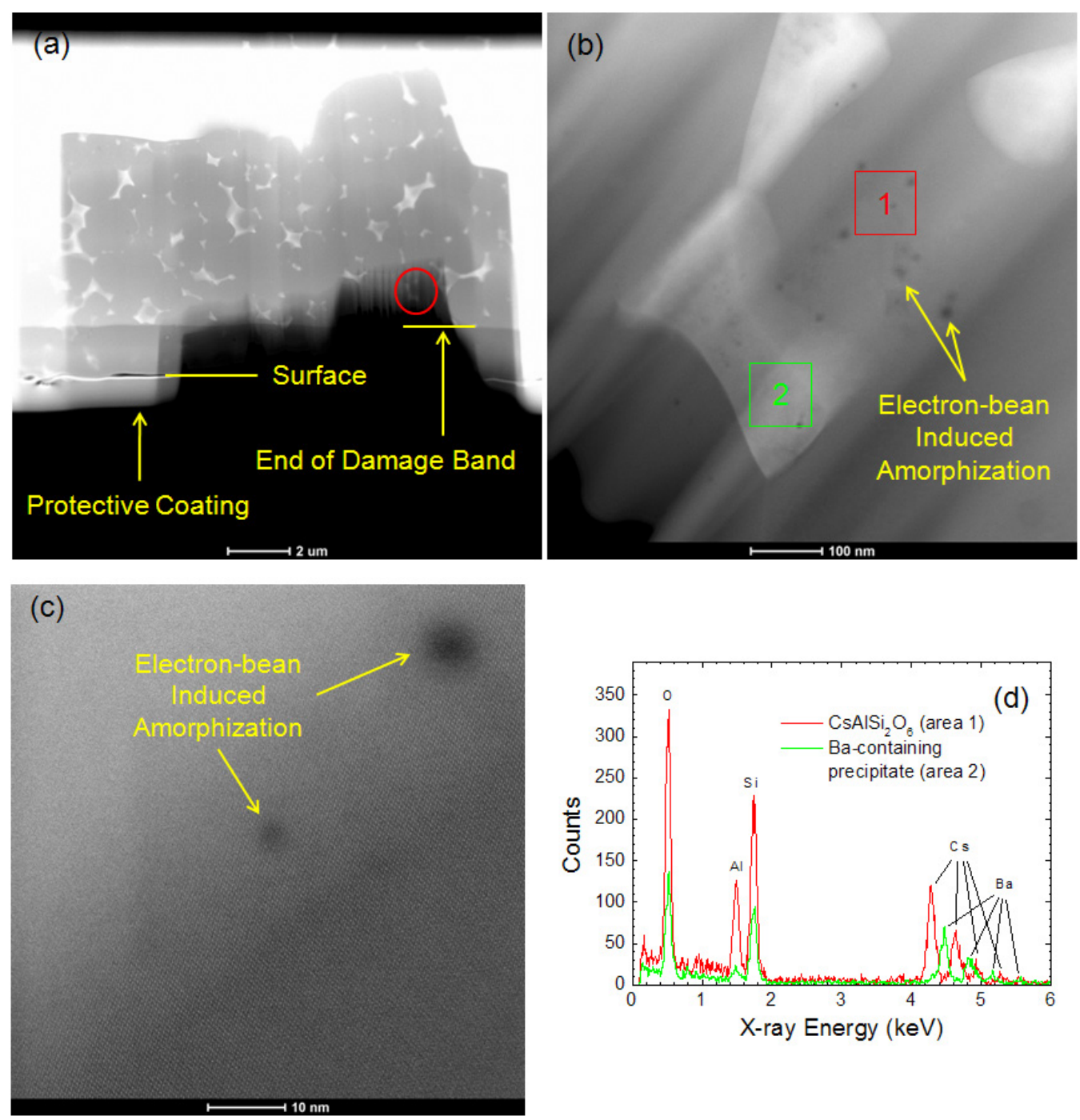

Figure 25. (a) Low-resolution HAADF TEM micrographs of $\mathrm{F}^{+}$ion implanted and $1073 \mathrm{~K}$ annealed $\mathrm{Cs}_{0.9} \mathrm{Ba}_{0.1} \mathrm{AlSi}_{2} \mathrm{O}_{6}$ pollucite. (b) Magnified area of $\sim 1.3 \mu \mathrm{m}$ away from the rear edge of the amorphization layer (circled area in (a)). (c) Magnified view of amorphization spots. (d) EDS spectra for areas 1 and 2 indicated in (b), showing area 1 is $\mathrm{CsAlSi}_{2} \mathrm{O}_{6}$ and area 2 a Ba-containing precipitate consisting of mainly $\mathrm{Ba}, \mathrm{Si}$ and $\mathrm{O}$.

addition, the Cs atoms in the wide channel are not perfectly aligned in a line along the [111] axis, as can also be seen from the $3 \mathrm{D}$ view in Fig. 1. The slightly misaligned arrangement decreases the atomic shielding and makes Cs atoms in the column more exposed to the incident electron beam, thus increasing the scattering probability. According to Fig. 26(a), the lattice constant is determined by the distance of two nearest Cs atoms $(\sim 1.03 \mathrm{~nm})$ in the wide channel divided by a factor of $(2 / 3)^{-1 / 2}$, i.e., $1.26 \mathrm{~nm}$, which is slightly smaller than the theoretical value of $1.367 \mathrm{~nm}$. Sample drift could contribute to error, but slightly compressed local structure also cannot be ruled out. 


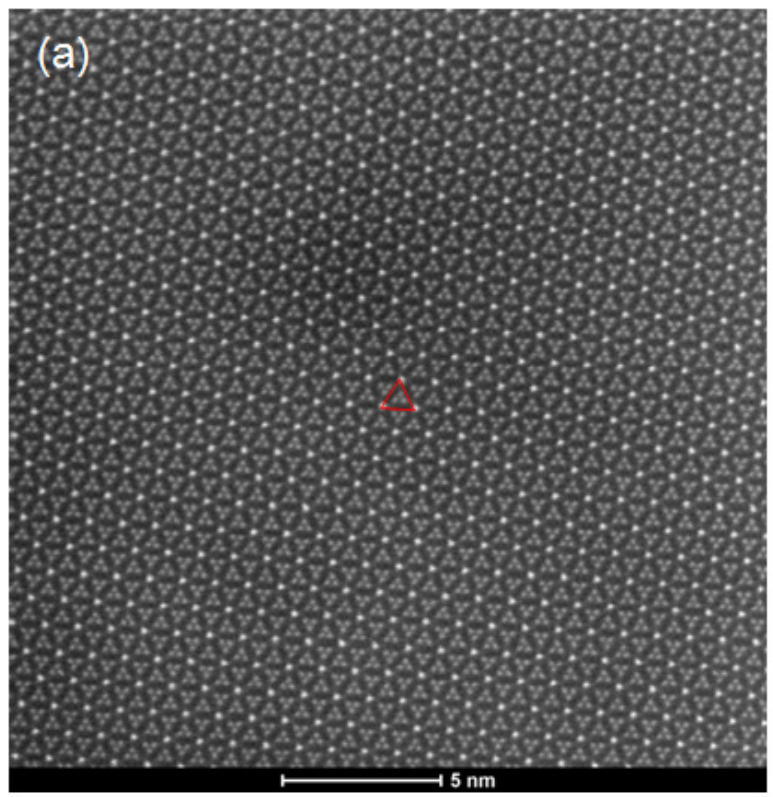

(b)

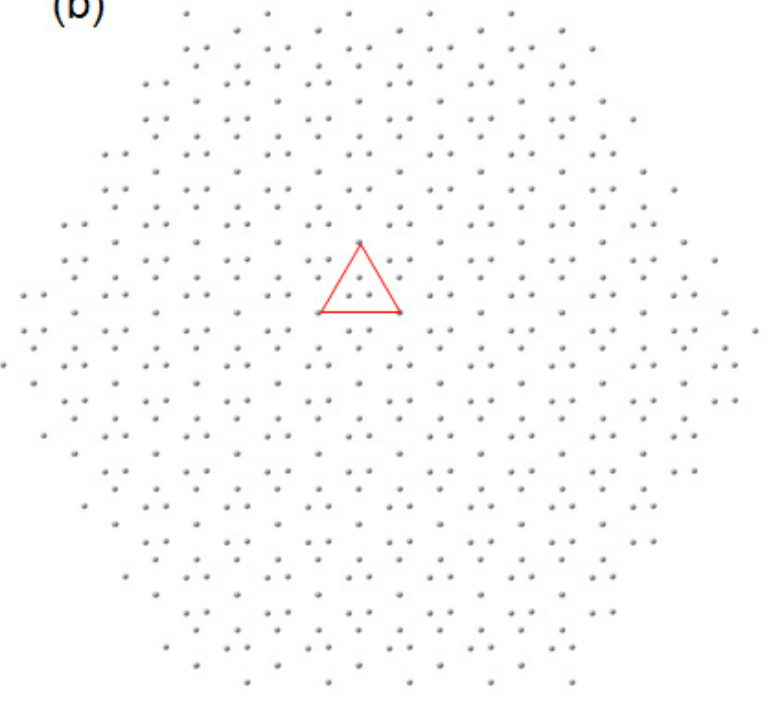

Figure 26. (a) Atomic-level resolution $\mathrm{HAADF}$ TEM micrograph of $\mathrm{CsAlSi}_{2} \mathrm{O}_{6}$ pollucite on the (111) projection plane. (b) Simulated atomic configuration of Cs in $\mathrm{CsAlSi}_{2} \mathrm{O}_{6}$ pollucite on the (111) projection plane. The triangle connects nearest Cs atoms in the wide channel.
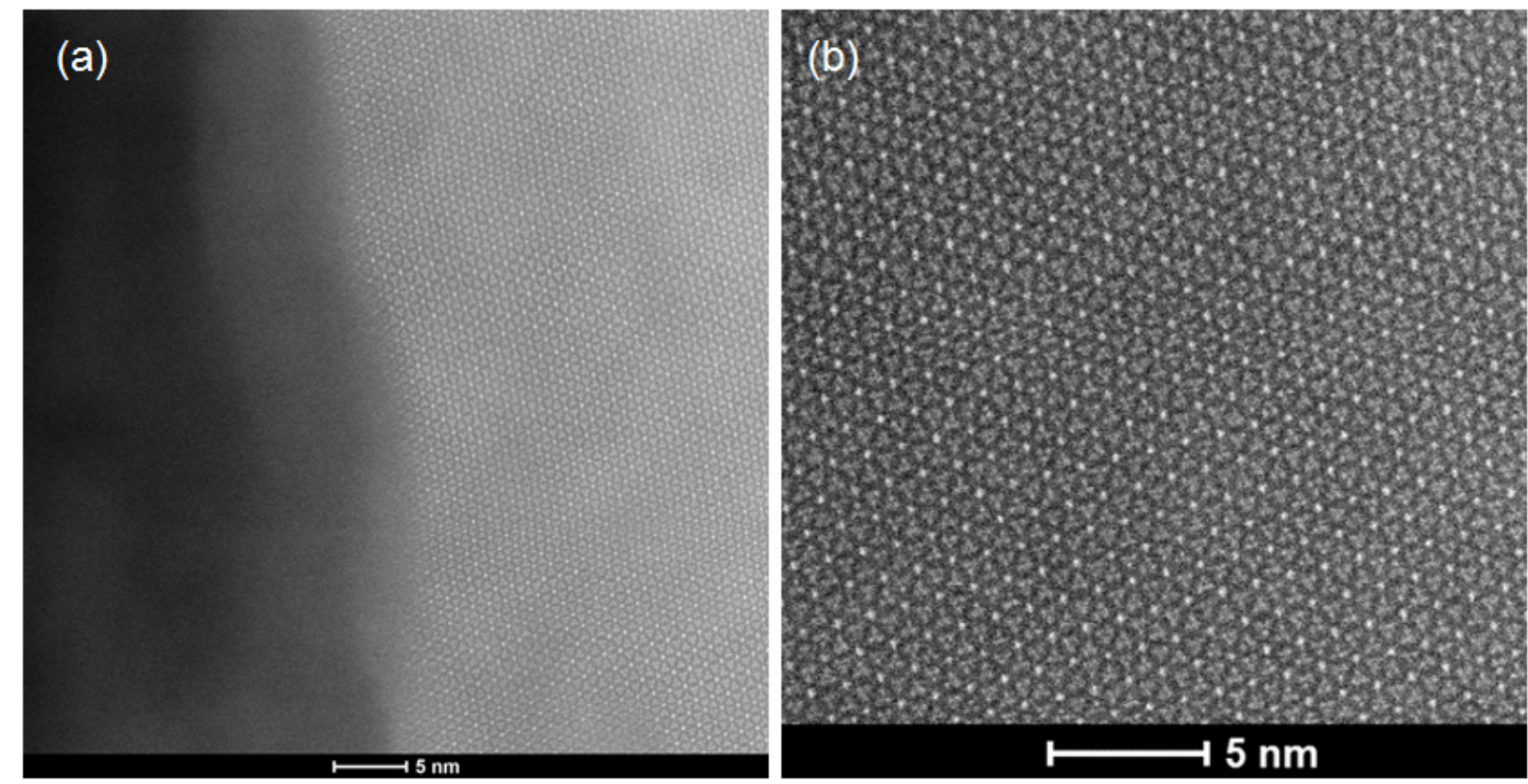

Figure 27. Atomic-level resolution HAADF TEM micrograph of (a) the crystalline/amorphous interface in $\mathrm{F}^{+}$ion implanted $\mathrm{Cs}_{0.9} \mathrm{Ba}_{0.1} \mathrm{AlSi}_{2} \mathrm{O}_{6}$ pollucite on the (111) projection plane, and (b) a crystalline region near the interface. 
Microstructures of the implanted/annealed $\mathrm{Cs}_{0.9} \mathrm{Ba}_{0.1} \mathrm{AlSi}_{2} \mathrm{O}_{6}$ near the crystalline/amorphous interface were also examined, where the implanted $\mathrm{F}$ could be incorporated into the pollucite structure. Figure 27(a) shows such an interface at an atomic-level resolution. EDS measurements were conducted across the interface and the results (data not shown) indicate that there is a maximum $\mathrm{F}$ concentration inside the amorphization layer, as expected, and the concentration at the interface is very small. A typical micrograph of the crystal structure near the interface is shown in Fig. 27(b). The Cs lattice in the pollucite structure on the (111) projection plane, similar to that in Fig. 26(a), appears to be perfect with a little distortion. It is not yet conclusive at this point that whether $\mathrm{Ba}$ and/or $\mathrm{F}$ have been incorporated into the crystal structure in a local region and what chemical roles they could play. Further studies are needed to understand the roles of $\mathrm{Ba}$ and $\mathrm{F}$ in the crystal structure and identify whether there are energetically preferable atomic configuration or precipitates with other phases.

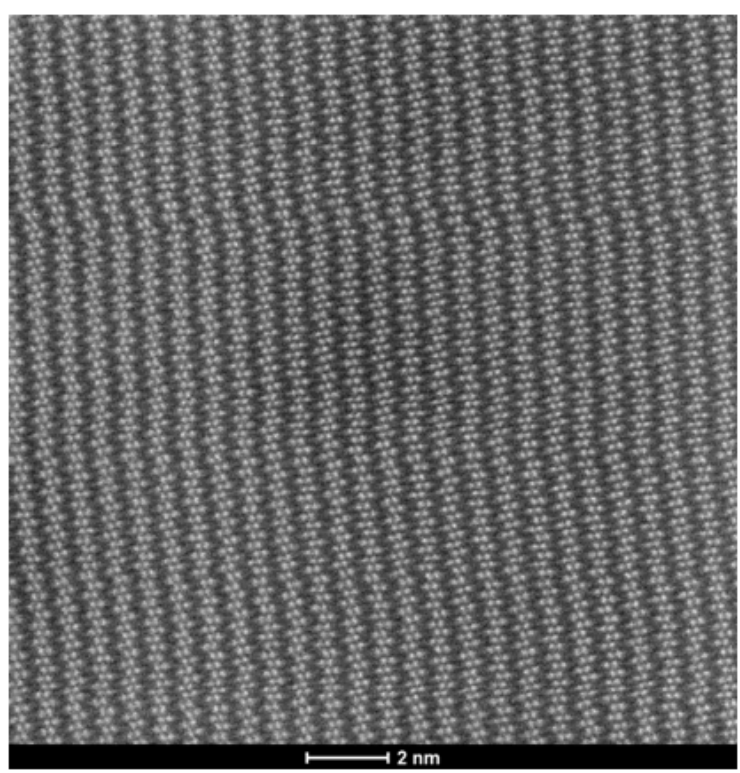

Figure 28. Atomic-level resolution HAADF TEM micrograph of a Ba-containing precipitate near the crystalline/amorphous interface. This includes higher-temperature implantation of $\mathrm{Ba}$ and $\mathrm{F}$ into pure pollucite that maintains its crystalline structure.

In addition, a Ba-containing precipitate near the interface was also selected for structural examination. Figure 28 shows the $\mathrm{Ba}$ lattice in the crystalline precipitate along a zone axis. Realignment of the crystal was necessary. The zone axis is not parallel to the [111] axis of its surrounding $\mathrm{CsAlSi}_{2} \mathrm{O}_{6}$. Preliminary analysis of the lattice structure suggests that the Ba-containing crystal is not likely to be the aluminosilicate pollucite phase. More work is required to determine the crystal structure, including imaging lattice configuration along other zone axes of the Ba-containing crystal.

\subsubsection{Cesium/barium diffusion and release}
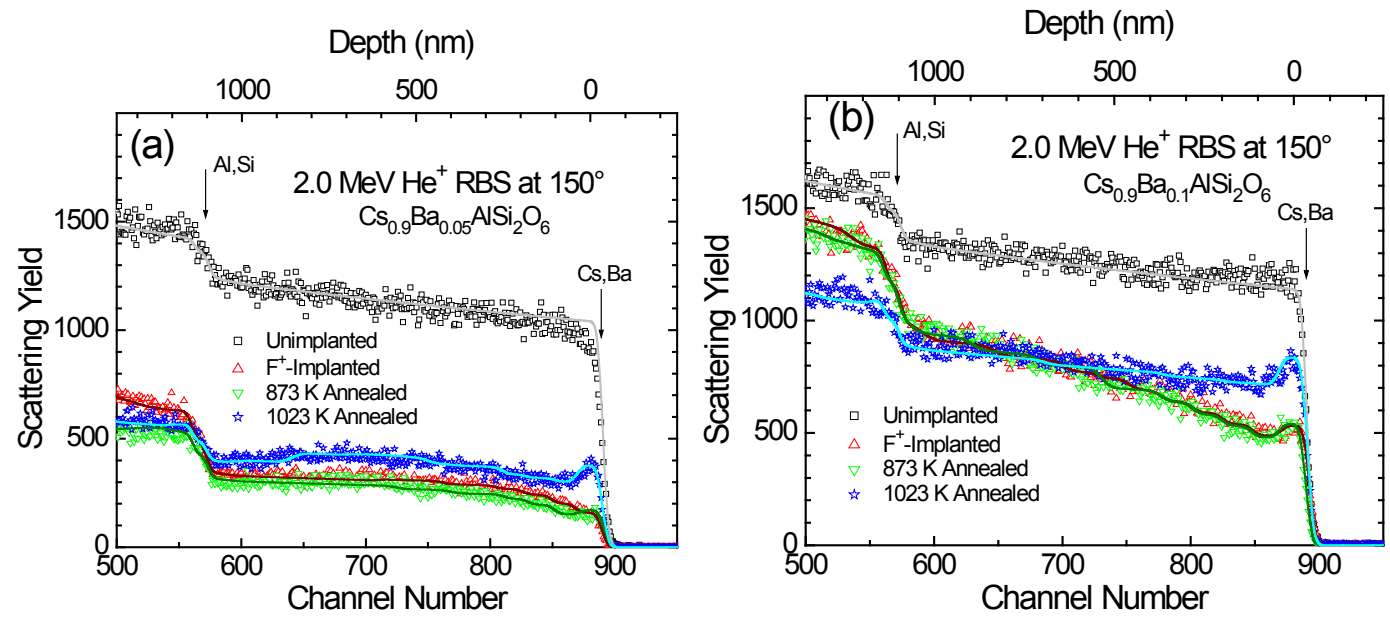

Figure 29. 2.0 MeV He ${ }^{+}$ion RBS spectra for (a) $\mathrm{Cs}_{0.9} \mathrm{Ba}_{0.05} \mathrm{AlSi}_{2} \mathrm{O}_{6}$ and (b) $\mathrm{Cs}_{0.9} \mathrm{Ba}_{0.05} \mathrm{AlSi}_{2} \mathrm{O}_{6}$ pollucite samples before and after $\mathrm{F}^{+}$ion implantation and thermal annealing at 873 and $1023 \mathrm{~K}$. Also included are the simulation results from code SIMNRA. 

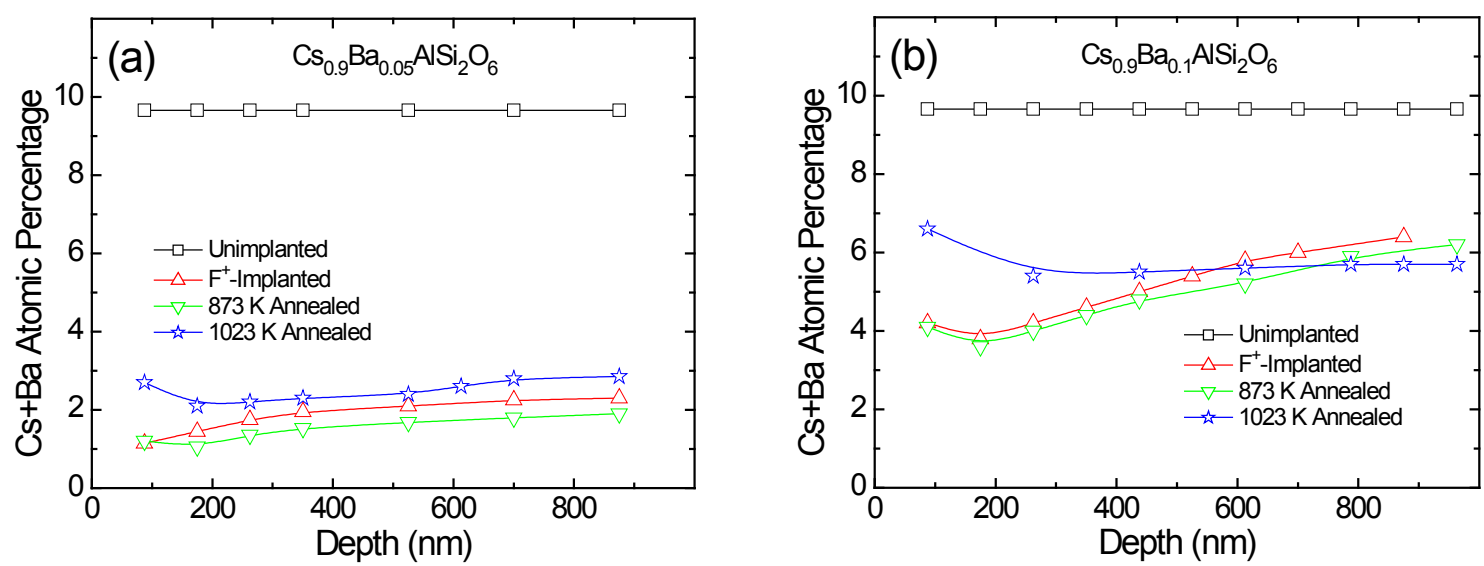

Figure 30. Depth profiles of $\mathrm{Cs}$ and $\mathrm{Ba}$ determined by SIMNRA simulations of the RBS spectra in Fig. 29 for Cs in (a) $\mathrm{Cs}_{0.9} \mathrm{Ba}_{0.05} \mathrm{AlSi}_{2} \mathrm{O}_{6}$ and (b) $\mathrm{Cs}_{0.9} \mathrm{Ba}_{0.05} \mathrm{AlSi}_{2} \mathrm{O}_{6}$ pollucite samples before and after $\mathrm{F}^{+}$ion implantation and thermal annealing at 873 and $1023 \mathrm{~K}$.

Figure 29 shows $2.0 \mathrm{MeV} \mathrm{He}{ }^{+}$ion RBS spectra for $\mathrm{Cs}_{0.9} \mathrm{Ba}_{0.05} \mathrm{AlSi}_{2} \mathrm{O}_{6}$ and $\mathrm{Cs}_{0.9} \mathrm{Ba}_{0.1} \mathrm{AlSi}_{2} \mathrm{O}_{6}$ pollucite samples before and after $\mathrm{F}^{+}$ion implantation and thermal annealing at 873 and $1073 \mathrm{~K}$. As described in section 4.2.2, Cs and $\mathrm{Ba}$, as well as $\mathrm{Al}$ and $\mathrm{Si}$, are not resolvable in the RBS spectra. For this reason, we do not distinguish $\mathrm{Cs}$ and $\mathrm{Ba}$ in this section. Because $\mathrm{Cs}$ has a significantly higher concentration than the doped $\mathrm{Ba}$, we use $\mathrm{Cs}$ representing both $\mathrm{Cs}$ and $\mathrm{Ba}$ in this section. The depth scale is estimated from the backscattering ion energy and is shown in Fig. 29. The maximum probing depth for Cs is about $1 \mu \mathrm{m}$ without spectrum overlap of $\mathrm{Cs}$ and $\mathrm{Si}$; the depth range is smaller than the thickness of the surface amorphization layer ( $1.7 \mu \mathrm{m}$ (Figs. 24(c) and 25(a)). Also included in Fig. 29 are the simulation results from code SIMNRA (indicated by solid lines), which well match each of the Cs and other elemental spectra. According to the simulations, the depth profiles of Cs in the pollucite samples are obtained and the data are plotted in Fig. 30. In general, there is a significant Cs diffusion to the surface and release to the vacuum during the $\mathrm{F}^{+}$ion implantation at $673 \mathrm{~K}$. At the end of the implantation, the Cs concentrations at the sample surfaces of $\mathrm{Cs}_{0.9} \mathrm{Ba}_{0.05} \mathrm{AlSi}_{2} \mathrm{O}_{6}$ and $\mathrm{Cs}_{0.9} \mathrm{Ba}_{0.1} \mathrm{AlSi}_{2} \mathrm{O}_{6}$ are 1.2 at.\% and 4.2 at.\%, respectively. Compared to the initial values in both unimplanted samples, Cs loss at the surface corresponds to $88 \%$ and $57 \%$, respectively. Part of the reasons for more Cs loss from $\mathrm{Cs}_{0.9} \mathrm{Ba}_{0.05} \mathrm{AlSi}_{2} \mathrm{O}_{6}$ may be bubble rupture, leading to more surface areas that can release $\mathrm{Cs}$ to vacuum more efficiently. In addition to the different Cs retentions in the two samples, the thermal annealing behavior is also different. The 5\% $\mathrm{Ba}$ doped pollucite shows no significant changes during annealing at 873 and $1073 \mathrm{~K}$. The loss of Cs is saturated and the Cs depth distribution remains largely the same except for some accumulation at the surface after annealing at $1073 \mathrm{~K}$. In contrast, Cs in the $10 \% \mathrm{Ba}$ doped sample that does not show observable bubbles (Fig. 24), exhibit a Cs concentration gradient along the depth in the amorphized layer of the as-implanted and $873 \mathrm{~K}$ annealed samples. Accumulation of $\mathrm{Cs}$ at the surface is evident and more accumulation occurs after annealing at $1073 \mathrm{~K}$. The Cs depth profile also becomes flatter over the depth region, suggesting a redistribution of $\mathrm{Cs}$ by diffusion at $1073 \mathrm{~K}$. As a result, the absolute Cs concentration becomes higher near the surface with little further Cs loss. The results suggest that Cs loss occurs mainly during ion irradiation, but not during thermal annealing up to $1073 \mathrm{~K}$.

In order to evaluate the loss rate of $\mathrm{Cs}$ in $\mathrm{Cs}_{0.9} \mathrm{Ba}_{0.1} \mathrm{AlSi}_{2} \mathrm{O}_{6}$ as a function of ion fluence, an in-situ RBS method was designed. The sample was irradiated using $2.0 \mathrm{MeV} \mathrm{He}^{+}$ions at room temperature, while at the same time, RBS data was registered. A total of 7 sequences on the same sample area were applied, each of which had an accumulated charge of $10 \mu \mathrm{C}$ over the beam spot of $\sim 0.8 \times 0.8 \mathrm{~mm}^{2}$, corresponding 
to ion fluence of $\sim 10^{16} \mathrm{He}^{+} / \mathrm{cm}^{2}$. Figure 31 shows the RBS spectra for selected ion fluences of $10^{16}$, $4 \times 10^{16}$ and $7 \times 10^{16} \mathrm{He}^{+} / \mathrm{cm}^{2}$. From the RBS data, there are no observable changes in the spectra, suggesting that Cs loss is insignificant under the irradiation conditions up to the highest fluence applied $\left(7 \times 10^{16} \mathrm{He}^{+} / \mathrm{cm}^{2}\right)$. Compared to $\mathrm{MeV} \mathrm{F}$ ions, $\mathrm{MeV} \mathrm{He}^{+}$ions deposit much less electronic (and nuclear) energy in the near surface region due to a lower $\mathrm{Z}$ and a higher velocity (and smaller mass). The material is not expected to be fully amorphized at the end of the $\mathrm{He}^{+}$ion irradiation. The results in Fig. 31 suggest that prior to amorphization of pollucite, Cs diffusion and release are negligible even under ion irradiation at room temperature.

\subsubsection{Chemical states}

Figure 32 shows the XPS spectra for all the six major elements in $\mathrm{Cs}_{0.9} \mathrm{Ba}_{0.1} \mathrm{AlSi}_{2} \mathrm{O}_{6}$ before and after $\mathrm{F}^{+}$ ion implantation and post thermal annealing at $1073 \mathrm{~K}$. No ion sputtering was applied prior to the XPS measurements in order to avoid possible changes in chemical states. Due to F diffusion (Fig. 22), a distinct $\mathrm{F}$ 1s peak is observed on the surface of the implanted/annealed sample, as shown in Fig. 32(a). As expected, fluorine is not observed at the surface of the unimplanted sample within the detection limit. The $\mathrm{O} 1 \mathrm{~s}$ peak prior to implantation is located at the binding energy of $531.5 \mathrm{eV}$ and shifts to $530.5 \mathrm{eV}$, as shown in Fig. 32(b), which is a typical value for chemical states in $\mathrm{Al}_{2} \mathrm{O}_{3}$ and $\mathrm{SiO}_{2}$. The $\mathrm{O}$ 1s peak becomes sharper probably due to a narrower distribution of $\mathrm{O}$ bond lengths in the amorphized material. Al $2 \mathrm{p}$ peak, partly overlapped with $\mathrm{Cs} 4 \mathrm{~d}$ peak, is located at $75.0 \mathrm{eV}$ before implantation and slightly shifted to a lower energy $(74.5 \mathrm{eV})$ that is closer to that for $\mathrm{Al}$ in $\mathrm{Al}_{2} \mathrm{O}_{3}$. The $\mathrm{Al} 2 \mathrm{p}$ peak becomes broader, suggesting that various chemical states are present in the amorphized material, but presence of elemental $\mathrm{Al}$ can be excluded because its binding energy is only $72.9 \mathrm{eV}$. There is also only a slight shift of binding energy of Si $2 p$ to the lower energy after $\mathrm{F}^{+}$ion implantation, as shown in Fig. 32(d). The value between 101 and $102 \mathrm{eV}$ is much larger than for $\mathrm{Si}$ in elemental $\mathrm{Si}(99.3 \mathrm{eV})$. Two well resolved $\mathrm{Cs} 3 \mathrm{~d}_{3 / 2}$ and $3 \mathrm{~d}_{5 / 2}$ peaks are observed and shown in Fig. 32(e) with the binding energy of 738.5 and 724.5, respectively, prior to implantation. Very small shift for Cs $3 \mathrm{~d}$ peaks occurs after implantation, but the peak intensities are greatly reduced, which could be associated with the Cs loss at the surface, as indicated by the RBS data shown in Figs. 29(b) and 30(b). Since the Cs $3 \mathrm{~d}_{3 / 2}$ and $3 \mathrm{~d}_{5 / 2}$ peaks for Cs metal are located at 740 and $726 \mathrm{eV}$, respectively, the remaining $\mathrm{Cs}$ in the amorphized material is not in the form of metal aggregates. There is about $0.5 \mathrm{eV}$ energy shift for both $\mathrm{Ba} 3 \mathrm{~d}_{3 / 2}$ and $3 \mathrm{~d}_{5 / 2}$ peaks to the higher energy after implantation and their binding energies are lower than in $\mathrm{Ba}$ metal, suggesting that $\mathrm{Ba}$ is present in a compound form in the amorphized material. It should be noted that the XPS system used in this study was well calibrated based on the well-known $\mathrm{C}$ peak to correct possible surface charging effect that could cause peak shifts. In all cases, the shape of each peak remains largely unchanged and clear fine structures or tails are not present after implantation and annealing. The data in Fig. 32 do not provide evidence about valence change of all the major elements in the amorphized material. 

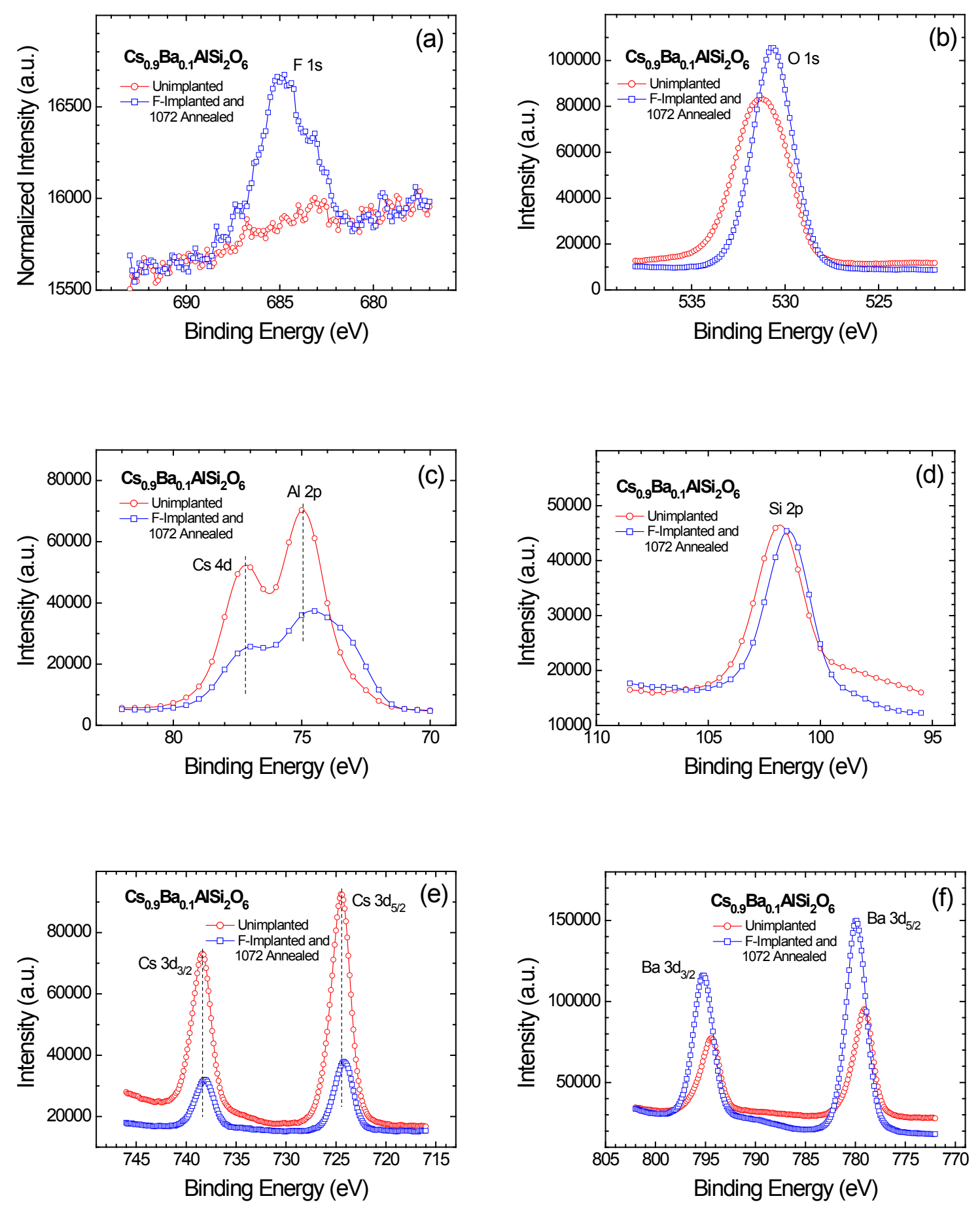

Figure 32. (a) F 1s, (b) O 1s, (c) Al 2p, (d) Si 2p, (e) Cs 3d, and (f) Ba 3d XPS spectra for as-sintered and $\mathrm{F}^{+}$ion implanted / $1073 \mathrm{~K}$ annealed $\mathrm{Cs}_{0.9} \mathrm{Ba}_{0.1} \mathrm{AlSi}_{2} \mathrm{O}_{6}$ without prior sputtering. 


\section{GENERAL DISCUSSION}

Pollucite has been widely investigated as a potential waste form to host radionuclide ${ }^{137} \mathrm{Cs}$. The results from this study indicate that pollucite structure can be readily amorphized under ionizing irradiation through radiolysis. Once amorphized, the material is difficult to recrystallize at temperatures up to $1073 \mathrm{~K}$ and Cs can be readily released from the amorphized material through out-diffusion. While $\beta^{-}$decay in the real waste form ${ }^{137} \mathrm{CsAlSi}_{2} \mathrm{O}_{6}$ produces a very low electron flux that is not expected to be high enough to amorphize the crystal structure, caution must be exercised if the waste form contains impurities of actinide elements that undergo $\alpha$ decays. Unlike $\beta^{-}$decay, both the energetic $\alpha$ particles and the daughter recoils can produce atomic displacements. Accumulation of simple and extended defects can lead to amorphization of the material below $673 \mathrm{~K}$. Consequently, Cs diffusion to the surface and release to the environment become likely. This could be a serious issue for the impure pollucite composition to be utilized as a viable waste form. It is important to determine the critical temperature for amorphization in pollucite, above which pollucite structure cannot be amorphized through the displacement and damage accumulation processes. Equally important is to study Cs behavior in pollucite under ionizing irradiation at temperatures above the critical temperature. Our further experimental investigations will be focused on implantation of $\mathrm{F}$ in $\mathrm{Ba}$ doped pollucite or co-implantation of $\mathrm{Ba}$ and $\mathrm{F}$ in pure pollucite at elevated temperatures so that full amorphization of the crystal structure is avoided. This will provide an opportunity to study the chemical roles of $\mathrm{Ba}$ and $\mathrm{F}$ in pollucite structure. Since Ba-containing precipitates are observed in the sintered pollucite samples, it is important to study whether such a phase is formed in pollucite structure through ion implantation and thermal annealing and clarify whether such a phase is energetically favorable in pollucite structure. In particular, the resulting structure containing $\mathrm{Ba}$ and incorporation of charge-compensating ions needs to be investigated to understand decay effects due to chemical change and charge imbalance. It is also our intention to study other ceramic materials that have Cs as an essential constituent and to explore them as potential candidates for ${ }^{137} \mathrm{Cs}$ waste forms, especially for those that have large singe crystals available for this study.

\section{CONCLUSIONS}

From this initial experimental study of aluminosilicate pollucite as a potential waste form for ${ }^{137} \mathrm{Cs}$, the following conclusions are made:

(1) The natural pollucite sample used in this study is determined to be a single crystal, but the crystalline quality is poor and the sample is not suitable for ion-channeling study.

(2) The synthesized samples of $\mathrm{CsAlSi}_{2} \mathrm{O}_{6}, \mathrm{Cs}_{0.9} \mathrm{Ba}_{0.05} \mathrm{AlSi}_{2} \mathrm{O}_{6}$ and $\mathrm{Cs}_{0.9} \mathrm{Ba}_{0.1} \mathrm{AlSi}_{2} \mathrm{O}_{6}$ have a cubic pollucite structure without water. The overall composition of each sample is nearly stoichiometric. However, minor phases of $\mathrm{Si}$ and/or $\mathrm{Al}$ oxides appear to be present. Impurities of $\mathrm{Na}$ and $\mathrm{Ca}$ at low levels are identified. The pollucite grain size ranges from $100 \mathrm{~nm}$ to $1 \mu \mathrm{m}$. Microscopically, there are regions of elemental enrichment and deficiency. Barium-containing precipitates with $\mathrm{Si}$ and $\mathrm{O}$ in the 10 at.\% Ba-dope pollucite are present and are located at the grain boundaries.

(3) High-dose $\mathrm{F}^{+}$ion implantation leads to amorphization of pollucite crystal even at temperatures as high as $673 \mathrm{~K}$. Substantial recrystallization does not occur during post annealing up to $1073 \mathrm{~K}$; A complete recrystallization of the amorphized pollucite appears to take place after annealing at $1423 \mathrm{~K}$ for 10 hours. Diffusion of the implanted $\mathrm{F}$ toward the surface is observed at $873 \mathrm{~K}$, and becomes more significant at $1073 \mathrm{~K}$ with $\mathrm{F}$ release. All the $\mathrm{F}$ in the sample is released at $1423 \mathrm{~K}$.

(4) Bubbles of $\mathrm{F}_{2}$ gas are formed in $\mathrm{F}^{+}$ion implanted $\mathrm{Cs}_{0.9} \mathrm{Ba}_{0.05} \mathrm{AlSi}_{2} \mathrm{O}_{6}$. In contrast, no gas bubbles are found in $\mathrm{Cs}_{0.9} \mathrm{Ba}_{0.1} \mathrm{AlSi}_{2} \mathrm{O}_{6}$ under the identical implantation conditions. Even after thermal annealing 
at $1073 \mathrm{~K}$, bubble formation does not occur. The results, together with the rather flat $\mathrm{F}$ depth profile in the sample after thermal annealing at $1073 \mathrm{~K}$, may suggest that $\mathrm{F}$ implants are trapped in the structure by forming chemical bonds, such as a bond with excess $\mathrm{Ba}$. The $\mathrm{BaF}^{+}$unit could potentially substitute for $\mathrm{Cs}^{+}$on the lattice site and stabilize the pollucite structure because of the charge balance. Further studies are needed to test the concept.

(5) The pollucite structure in the unimplanted region of $\mathrm{Cs}_{0.9} \mathrm{Ba}_{0.1} \mathrm{AlSi}_{2} \mathrm{O}_{6}$ shows a perfect Cs lattice arrangement, which is consistent with the theoretical prediction. The material is susceptible to electron irradiation induced amorphization at electron energy of $300 \mathrm{keV}$. Since atomic displacements are unlikely to occur at the low incident energy, amorphization is attributed primarily to electronic energy deposition that leads to material decomposition (radiolysis). Near the crystalline/amorphous interface, $\mathrm{F}$ concentration is very small and it is yet unknown whether $\mathrm{F}$ and/or $\mathrm{Ba}$ is incorporated into the pollucite structure. Further efforts are planned to address the issue.

(6) Ba-containing precipitates are crystalline and likely to have a structure different from pollucite. More work is required to determine the phase of the Ba-containing precipitate.

(7) Cesium is diffusive in amorphized pollucite under ionizing irradiation at elevated temperatures and can be readily released from the sample. About $88 \% \mathrm{Cs}$ in the amorphized pollucite are released to vacuum during the high-dose $\mathrm{F}^{+}$ion implantation at $673 \mathrm{~K}$ in $\mathrm{Cs}_{0.9} \mathrm{Ba}_{0.05} \mathrm{AlSi}_{2} \mathrm{O}_{6}$ and about $57 \%$ in $\mathrm{Cs}_{0.9} \mathrm{Ba}_{0.1} \mathrm{AlSi}_{2} \mathrm{O}_{6}$. However, prior to amorphization, there is no evidence from this study that shows $\mathrm{Cs}$ loss during ion irradiation at room temperature.

(8) The experimental data from this study suggest that all the essential constituents in the amorphized pollucite are in the oxide or compound states. No evidence is found for formation of any elemental material, including $\mathrm{Cs}$ and $\mathrm{Ba}$ metals. There is also no evidence showing a valence change of all the major elements after the material is fully amorphized. 


\title{
PART II: THEORY
}

\author{
R. M Van Ginhoven and J.E Jaffe
}

\section{ABSTRACT}

This part summarizes the main theoretical results for January to September 2012 under project "Chemical and Charge Imbalance Induced by Radionuclide Decay: Effects on Waste Form Structure" for the investigation of the effects of the decay of $\mathrm{Cs}$ to $\mathrm{Ba}$ in pollucite. The decay-induced chemical effects of ${ }^{137} \mathrm{Cs}^{+}$to ${ }^{137} \mathrm{Ba}^{2+}$ in the model waste form aluminosilicate pollucite $\mathrm{CsAlSi}_{2} \mathrm{O}_{6}$ are simulated using density functional theory (DFT).

Pollucite is a challenging material to study with electronic structure methods due both to the large unit cell (160 atoms), and the requirement to account for the disordered arrangement of $\mathrm{Al}$ and $\mathrm{Si}$ atoms in the network structure. After careful analysis of the effects of the Al distribution, we determined that the precise distribution has only a minor effect on the system energy, and therefore we can justify the study of $\mathrm{Ba}$ impurities using only one type of configuration. The calculation set on the selected configuration included systems ranging from 1 to $16 \mathrm{Ba}$ atoms substituted for $\mathrm{Cs}, 0$ to $16 \mathrm{Cs}$ vacancies, and excess interstitial oxygen to coincide with the implantation experiments. The results show that the removal (or escape) of Cs is energetically unfavorable in the pollucite crystal. The lowest equilibrium energy is achieved by precipitating half the $\mathrm{Ba}$ (as metal, or as $\mathrm{BaO}$ if oxygen is supplied by environment) so the remaining $\mathrm{Ba}(\mathrm{Cs})$ is compensated by $\mathrm{Cs}$ vacancies. This means that as the waste form decays, remaining Cs should stay trapped. However, information about ion mobilities, and especially the effects of network damage is still needed before a full assessment of pollucite can be made.

We find that excess oxygen binds to multiple $\mathrm{Ba}$ atoms to form $\mathrm{BaO}$ or $\mathrm{Ba}_{2} \mathrm{O}$. Also, at equilibrium, $\mathrm{Ba}$ tends to segregate into Ba-rich regions. This is consistent with the segregation of $\mathrm{Ba}$ that is seen in the analysis of the Ba-doped pollucite sample provided by Sandia Laboratory. Thus it is also necessary to consider the effects of $\mathrm{Ba}$ metal or oxide precipitation in the decaying waste form.

\section{INTRODUCTION}

A major obstacle to the widespread use of nuclear power is the problem of long-term storage and disposal of waste matter from spent fuel rods. Since a large share of the radioactivity from these materials is initially in fission products, above all ${ }^{90} \mathrm{Sr}$ and ${ }^{137} \mathrm{Cs}$, it may make sense to separate these elements and bury them in chemically stable solid matrices especially adapted for each element. One waste form that has been considered [Strachan 1979] for Cs is the nanoporous aluminosilicate pollucite, $\mathrm{CsAlSi}_{2} \mathrm{O}_{6}$. Pollucite holds promise for this application [Sanchez-Valle 2010] due to its hydrothermal stability [S. Komameni 1981; Mimura 1990; Yanagisawa 1987], low thermal expansion[Kobayashi 1997; Kobayashi 2006] and high weight fraction of cesium. Experimentally, the $\mathrm{Al}$ and $\mathrm{Si}$ atoms share a single sublattice with a random distribution, and are coordinated with oxygen to form $\mathrm{Al}_{1 / 3} \mathrm{Si}_{2 / 3} \mathrm{O}_{4}$ tetrahedra which share corners to form 4-, 6- and 8-member rings. The Cs ions compensate for the valence difference between $\mathrm{Al}$ and $\mathrm{Si}$, and are located in the 6-member ring channels without close bonds to other atoms. The structure of pollucite is shown in Fig. 33. 

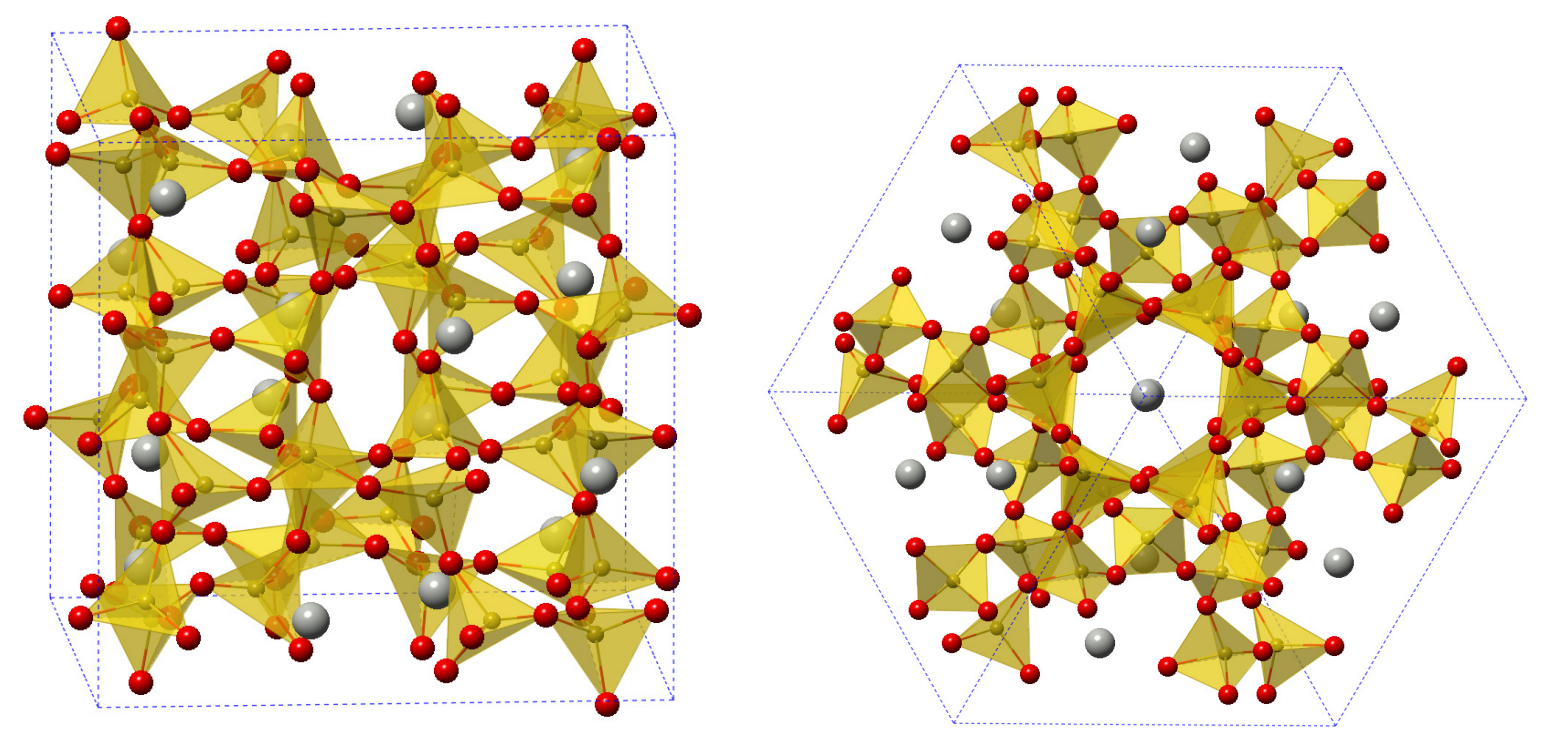

Figure 33. The structure of the pollucite unit cell, $\mathrm{Cs}_{16} \mathrm{Al}_{16} \mathrm{Si}_{32} \mathrm{O}_{96}$, viewed along the $<100>$ and $<111>$ directions. Cs is in silver, oxygen is red, and the amber tetrahedra are Si or Al. Two thirds of the tetrahedral are silicon, one third are aluminum, distributed randomly, with the constraint that no two Al tetrahedral are adjacent. The pollucite crystal is in the space group $I a 3 d$, isostructural with analcime, with $\mathrm{Cs}$ at the analcime $\mathrm{H}_{2} \mathrm{O}$ sites. Common impurities include $\mathrm{Rb}, \mathrm{Na}$, and $\mathrm{H}_{2} \mathrm{O}$.

Several issues affect the long-term stability of radioactive waste forms. Besides local damage to the atomic structure of a solid due to energetic decay events, self-heating and interaction with environmental water, oxygen or other substances, the transmutation of the constituent radioactive atoms from one column of the periodic table to another may make the original crystal or amorphous structure of the waste form energetically unfavorable, leading to structural changes accompanied by strain fields, volume changes, cracking or formation of precipitates. In the case of $\mathrm{Cs}$, the transformation is by way of beta decay to barium. Given the amount of open space around the Cs ions, the change in ionic radius in transforming to $\mathrm{Ba}$ seems unlikely to greatly affect the stability of the solid, however the change in valence from $\mathrm{Cs}^{+}$to $\mathrm{Ba}^{2+}$ (assuming the $\mathrm{Ba}$ is ionized to its full formal valence, as expected from its low electronegativity) means adding one electron per $\mathrm{Ba}$ to the conduction band states of the crystal, and this may eventually favor some form of structural change or chemical reaction, as the Ba concentration increases. However, very little is known about Ba-substituted Cs pollucite. There has been one unpublished experimental study [Fortner 1999] that indicated stability of pollucite with surprisingly high concentrations of substitutional $\mathrm{Ba}$, but the reasons for and limits of this stability, and the role of the chemical environment and other factors, are not well understood.

We have undertaken first-principles density-functional-theory computational modeling to try to better understand the factors affecting the thermodynamic stability of $\mathrm{CsAlSi}_{2} \mathrm{O}_{6}$ with varying amounts of Cs replaced by $\mathrm{Ba}$, along with certain other defects (electron acceptors) which may compensate for the electronic effects of $\mathrm{Ba}$ on $\mathrm{Cs}$ sites. Kinetic effects including diffusion will not be explicitly calculated in this paper but may also be very important. We note that only one first-principles description [Anchell 1994] of pollucite and related alkali metal aluminosilicates has been published, and it did not consider radioactive decay products such as Ba. 


\section{COMPUTATIONAL APPROACH}

Total energies of stoichiometric and defected pollucite unit cells were performed with the VASP [Kresse 1996] density functional code. Electron-core interactions were handled by the projector-augmented-wave (PAW) [Blöchl 1994] method with a plane-wave kinetic energy cutoff of $400 \mathrm{eV}$ and a $2 \times 2 \times 2$ Monkhorst-Pack [Monkhorst 1976] Brillouin-zone grid. Exchange and correlation were treated in the generalized gradient approximation (GGA) density functional of Perdew, Burke and Ernzerhof [Perdew 1996], and atomic coordinates and unit cell parameters were optimized until changes in total energy were less than $0.001 \mathrm{eV}$, corresponding to forces less than about $0.03 \mathrm{eV} / \AA$. Reference energies for bulk Ba and $\mathrm{Cs}$ metal, cubic $\mathrm{BaO}$ and rhombohedral $\mathrm{Cs}_{2} \mathrm{O}$ were calculated with optimized bulk crystal structures at similar precision to the pollucite calculations, and the energy of a single, spin-unconstrained $\mathrm{O}_{2}$ molecule was calculated in a large, otherwise-empty unit cell. Spin-orbit and finite-temperature effects were not included.

\section{MODEL RESULTS}

\subsection{Structure of Pollucite}

The primitive unit cell for the pollucite structure has 160 atoms, 16 formula units of the ideal $\mathrm{CsAlSi}_{2} \mathrm{O}_{6}$ composition, for a full formula of $\mathrm{Cs}_{16} \mathrm{Al}_{16} \mathrm{Si}_{32} \mathrm{O}_{96}$. The cell is approximately cubic (a slight tetragonal distortion developed as we minimized the energy in our calculations) with lattice constants of approximately $1.3 \mathrm{~nm}$. This cell is large enough that periodic images of a point defect in a periodic calculation should have relatively little spurious interaction. Therefore we used the actual pollucite cell as our computational unit cell, as opposed to constructing a larger model supercell.

The first challenge that we encounter in modeling pollucite is appropriately accounting for the disordered arrangement of aluminum atoms in the framework. It is possible that the relative placement of $\mathrm{Al}$ atoms may affect the stability of the structure, so it is necessary to examine multiple possible structures. There are two possible approaches to this problem. The first is a "brute force" approach, in which many
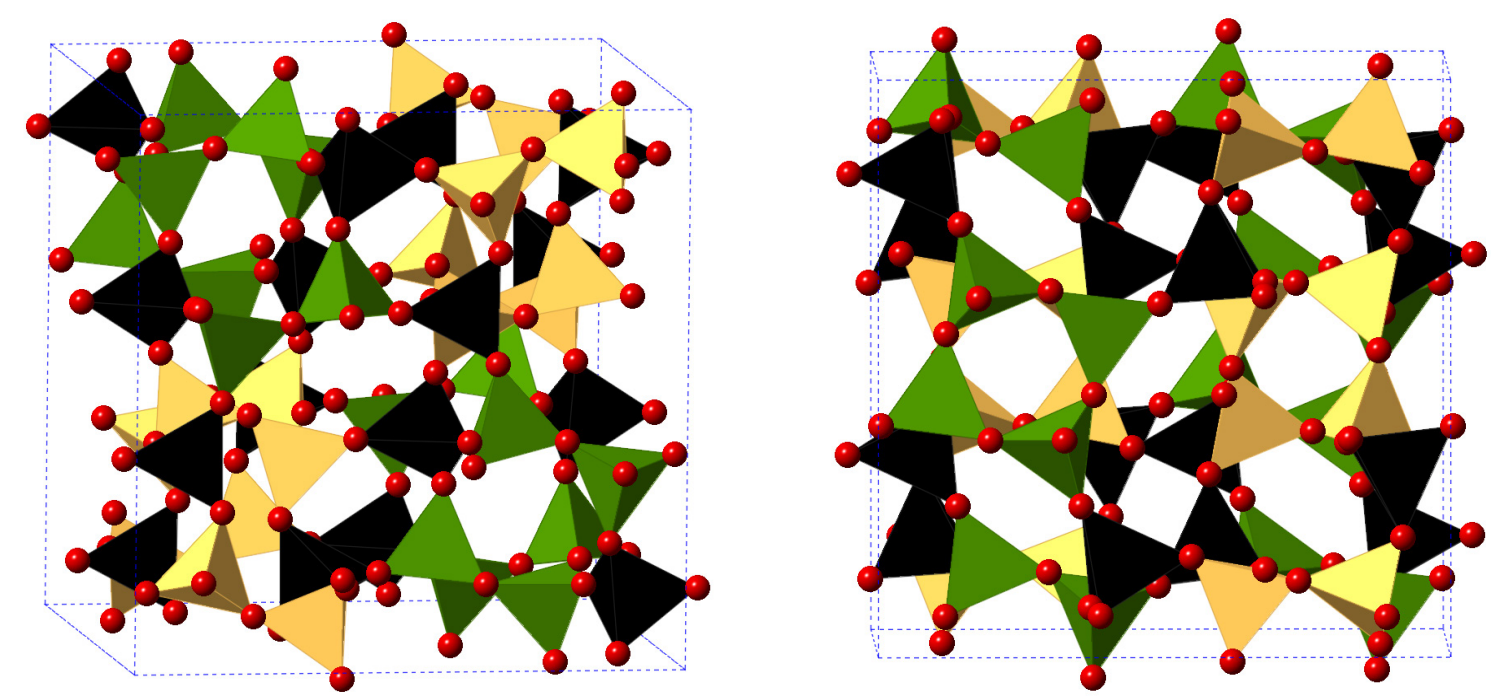

Figure 34. The optimized structure of the pure silica analogue of the pollucite structure. The structure is viewed along the a (left) and c (right) axes. The $48 \mathrm{Si}$-centered tetrahedra are divided into groups by structural variation in Si-O bonding. These sets are color coded; A is black, B is, green and $\mathrm{C}$ is yellow. The red spheres joining the tetrahedral corners are oxygen. 


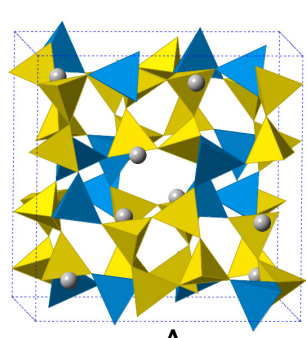

A

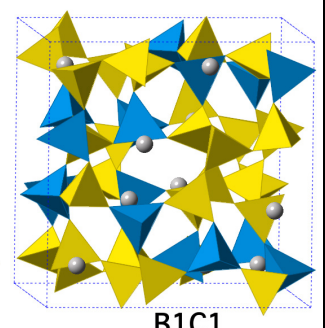

B1C1
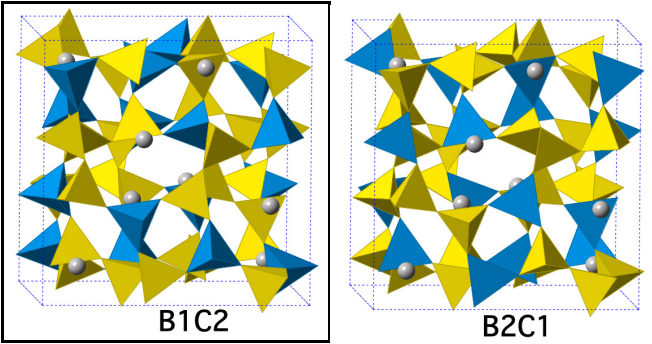

Figure 35. Aluminum distributions in pollucite. Cesium is depicted in silver, blue tetrahedra are Al, and yellow tetrahedra are Si. Oxygen atoms are not shown, for clarity. Configuration B1C2, marked with a border, is the lowestenergy structure, and was used for further investigation in this work.

randomly arranged configurations are generated and minimized. The second approach is to find a selection of ordered or pseudo-ordered arrangements that provide a representative sampling. We chose the second approach.

Initially, we examined the pure silicate zeolite analogue of the pollucite framework structure. This is the experimental coordinates for pollucite, without $\mathrm{Cs}$ atoms, and all framework atoms assigned as $\mathrm{Si}$. We performed an energy minimization on this structure. The resulting total energy was very close to the energy per formula unit calculated for quartz, as expected. The $48 \mathrm{Si}$ atoms in our zeolite unit cell were observed to divide themselves into three sets of 16 atoms each, on the basis of identical nearest-oxygen distances within each set but slightly different distances between sets. This division is illustrated in Fig. 34. Designating the three sets of Si sites as A, B and C, (black, green and yellow in Fig. 34, respectively) the second neighbor metal-metal coordination was observed to have the following properties: (i) each A atom has two $\mathrm{B}$ and two $\mathrm{C}$ second neighbors, but no set $\mathrm{A}$ second neighbors; (ii) each $\mathrm{B}$ had two A and two B second neighbors; and (iii) each $\mathrm{C}$ atom had two $\mathrm{A}$ and two $\mathrm{C}$ second neighbors. Thus, given the expectation that Al-O-Al bonds would be energetically less favorable than Al-O-Si bonds, one reasonable ordered model for the $(\mathrm{Si}, \mathrm{Al})$ sites in pollucite would be to put all the $\mathrm{Al}$ atoms on the $\mathrm{A}$ sites. However, the lattice coordination has the additional property that the sets $\mathrm{B}$ and $\mathrm{C}$ has subsets which we call $\mathrm{B} 1, \mathrm{~B} 2$, $\mathrm{C} 1$ and $\mathrm{C} 2$, with eight atoms each, such that $\mathrm{B} 1$ atoms have exactly two $\mathrm{B} 2$ and two $\mathrm{A}$ second neighbors, $\mathrm{B} 2$ atoms likewise have only $\mathrm{B} 1$ and $\mathrm{A}$ second neighbors, and similarly for $\mathrm{C} 1$ and $\mathrm{C} 2$. Thus, there are at least five models for an ordered arrangement of the $\mathrm{Al}$ atoms on the $(\mathrm{Si}, \mathrm{Al})$ sublattice of pollucite that produce no Al-O-Al chains, which we designate according to the sites occupied by $\mathrm{Al}$ as $\mathrm{A}, \mathrm{B} 1 \mathrm{C} 1, \mathrm{~B} 1 \mathrm{C} 2$, $\mathrm{C} 2 \mathrm{~B} 1$ and $\mathrm{C} 2 \mathrm{~B} 2$. At the same time that we set 16 atoms to be $\mathrm{Al}$, we also placed the $16 \mathrm{Cs}$ atoms initially at their experimental locations to produce five different models for the unit cell of pollucite. These arrangements are shown in Fig. 35. The energy differences among these five models are quite small, as illustrated in Table 5.

Table 5. Computed ground state energies and heat of formation, from binary oxides $\mathrm{Cs}_{2} \mathrm{O}, \mathrm{Al}_{2} \mathrm{O}_{3}$ and $\mathrm{SiO}_{2}$, of five model pollucite structures (per $\mathrm{CsAlSi}_{2} \mathrm{O}_{6}$ formula unit.)

\begin{tabular}{c|cc} 
Model & $\boldsymbol{E}_{\mathbf{0}} \mathbf{( e V / f o r m u l a}$ unit $)$ & $\boldsymbol{\Delta H}_{\mathbf{f}}(\mathbf{e V} /$ formula unit $)$ \\
\hline \hline A & -73.52 & -13.68 \\
B1C1 & -73.42 & -13.58 \\
B1C2 & -73.60 & -13.76 \\
B2C1 & -73.59 & -13.75 \\
B2C2 & -73.49 & -13.65
\end{tabular}


The lowest-energy unit cell B1C2 was used to study the Ba-for-Cs substitution along with native defects as described below. Based on charge density distributions, the Cs sites were determined to divide themselves into two subsets of eight sites each, denoted by lower-case letters $a$ and $b$. The two sets differ in the identity of their nearest-neighbor tetrahedra; set $a$ has two Si tetrahedra, and set $b$ has one Si and one $\mathrm{Al}$ tetrahedron. The energy cost of a single $\mathrm{Ba}$ substitution for $\mathrm{Cs}$ (neutral $\mathrm{Ba}_{\mathrm{Cs}}$ ) was determined to be lower by $0.19 \mathrm{eV}$ on the $b$ sites compared to the $a$ sites. Conversely, the formation energy of a single Cs vacancy (neutral $V_{\mathrm{Cs}}$ ) was $0.06 \mathrm{eV}$ lower on the $a$ sites than on the $b$ sites. Hence, in modeling pollucite cells with various numbers of $\mathrm{Ba}_{\mathrm{Cs}}$ and $V_{\mathrm{Cs}}$ defects we always place the $\mathrm{Ba}_{\mathrm{Cs}}$ on the $b$ sites and the $V_{\mathrm{Cs}}$ on the $a$ sites, though we cannot be certain of finding the configuration with the lowest possible energy in all cases. Rather, we seek representative structures to give a reasonable estimate of thermodynamic stability for various compositions.

\subsection{Ba Substitution and the Predicted Fate Ba Atoms on Cs Sites in Pollucite}

As a cesium waste form evolves, the fraction of the initial radioactive Cs which has decayed to Ba will increase towards $100 \%$. Therefore, we consider various concentrations of the decay product up to maximum values. Accordingly, we calculated total energies for unit cells with $1,2,4,8$ and $16 \mathrm{Ba}_{\mathrm{Cs}}$ defects, where the cell with $16 \mathrm{Ba}_{\mathrm{Cs}}$ corresponds to total replacement of Cs. For two $\mathrm{Ba}_{\mathrm{Cs}}$ defects, we calculated the energy for Ba pairs with several different spatial separations, and found the lowest energy for the most closely-spaced pair. Based on this attractive interaction between $\mathrm{Ba}$ impurities, we constructed the other unit cells with tightly-clustered $\mathrm{Ba}$ atoms on the available $\mathrm{Cs}$ sites. As long as the unit cell remains electrically neutral, each of these $\mathrm{Ba}_{\mathrm{Cs}}$ defects adds one extra electron to the conduction band of the system. Since pollucite is a wide-bandgap oxide, this excess n-type doping may be expected to greatly raise the energy of the system, leading to atomic rearrangements to reduce the number of electrons in these high-energy states. Accordingly, we also considered models in which the $\mathrm{Ba}_{\mathrm{Cs}}$ defects are compensated by the creation of Cs vacancies in equal numbers. We treated models with 1, 2, 4 and 8 $\mathrm{Ba}_{\mathrm{Cs}}-V_{\mathrm{Cs}}$ pairs in a unit cell, including several different impurity-vacancy site distances for the single pair; the lowest energy was found for a separation of $7.55 \AA$ between the impurity and vacant sites. Two nearby vacancies were added to the lowest-energy Ba-Ba pair to produce the cell with two $\mathrm{Ba}_{\mathrm{Cs}}-V_{\mathrm{Cs}}$ pairs, while four vacancies were added to the four-Ba unit cell to provide an example of a cell with $8 \mathrm{Ba}_{\mathrm{Cs}}-V_{\mathrm{Cs}}$ pairs. Finally, by placing eight $\mathrm{Ba}$ atoms on the $b$ sites and removing all the remaining Cs from the $a$ sites, we obtained a model unit cell with eight $8 \mathrm{Ba}_{\mathrm{Cs}}-V_{\mathrm{Cs}}$ pairs.

We describe the thermodynamic stability of $\mathrm{Ba}_{\mathrm{Cs}}$ defects and defect clusters in terms of changes in the total internal energy of pollucite when a defective cell converts into something else, e.g. a different defect plus precipitation or uptake of bulk $\mathrm{Cs}$ or $\mathrm{Ba}$ or their oxides, on a per-defect basis. Neglecting external pressure, these energy changes are equivalent to heats of reaction (enthalpy changes) and are denoted as such. We do not explicitly include the effects of externally imposed chemical potentials for the elements being exchanged with the environment, but do consider separately the effects of having or not having atmospheric oxygen in contact with the waste form.

\subsubsection{Point defect formation energies, and vacancy-Ba complex formation}

For the reactions that form the isolated point defects $\mathrm{Ba}_{\mathrm{Cs}}$ and $V_{\mathrm{Cs}}$, not showing unit cells of pure pollucite explicitly,

$\begin{array}{ll}\mathrm{Ba}(\text { metal }) \rightarrow \mathrm{Ba}_{\mathrm{Cs}}+\mathrm{Cs} \text { (metal), } & \Delta H=2.25 \mathrm{eV} \\ \text { No defect } \rightarrow V_{\mathrm{Cs}}+\mathrm{Cs} \text { (metal), } & \Delta H=6.51 \mathrm{eV} .\end{array}$ 
The exothermicity of these reactions simply indicates that the defect formation energies are positive; specifically, Ba will not spontaneously replace Cs in pollucite, nor will the material spontaneously expel Cs by forming vacancies. For the combination of the two point defects into the lowest-energy complex found in our calculations,

$$
\mathrm{Ba}_{\mathrm{Cs}}+V_{\mathrm{Cs}} \rightarrow\left(\mathrm{Ba}_{\mathrm{Cs}}+V_{\mathrm{Cs}}\right)_{\text {complex }}, \quad \Delta H=-6.50 \mathrm{eV},
$$

Indicating a strong attractive interaction between a pre-existing $\mathrm{Cs}$ vacancy and a substitutional $\mathrm{Ba}$. This attraction reflects the large energy gain from compensating the donor $\mathrm{Ba}_{\mathrm{Cs}}$ with the acceptor $V_{\mathrm{Cs}}$, this gain in turn being a consequence of the wide band gap of insulating silicates like pollucite.

\subsubsection{Transformations of an isolated $\mathrm{Ba}_{\mathrm{Cs}}$ defect}

Barium will not precipitate from pollucite simply by leaving behind a vacancy, as the following reaction is predicted to be quite endothermic:

$$
\mathrm{Ba}_{\mathrm{Cs}} \rightarrow V_{\mathrm{Cs}}+\mathrm{Ba} \text { (metal), } \quad \Delta H=4.26 \mathrm{eV}
$$

However, there is only a very slight energy cost to expel a $\mathrm{Cs}$ atom from the neighborhood of a $\mathrm{Ba}$ atom into a precipitate, through formation of the tightly-bound Ba-vacancy complex:

$\mathrm{Ba}_{\mathrm{Cs}} \rightarrow\left(\mathrm{Ba}_{\mathrm{Cs}}+V_{\mathrm{Cs}}\right)_{\text {complex }}+\mathrm{Cs}($ metal $), \quad \Delta H=0.02 \mathrm{eV}$.

On the other hand, expelling half the isolated $\mathrm{Ba}$ from $\mathrm{Cs}$ sites into a metallic $\mathrm{Ba}$ precipitate, while complexing the remainder with the resulting vacancies, turns out to be exothermic:

$\mathrm{Ba}_{\mathrm{Cs}} \rightarrow 0.5\left(\mathrm{Ba}_{\mathrm{Cs}}+V_{\mathrm{Cs}}\right)_{\text {complex }}+0.5 \mathrm{Ba}$ (metal), $\Delta H=-1.12 \mathrm{eV}$.

Reaction (6) is fundamentally the one that we predict is thermodynamically most favored, though we will see below that clustering or phase separation of the Ba-vacancy pairs may lower the energy even more.

If oxygen is able to enter to enter the waste form from the environment, several different oxidation pathways are found to be exothermic.

$$
\begin{array}{ll}
\mathrm{Ba}_{\mathrm{Cs}}+0.5 \mathrm{O}_{2} \rightarrow V_{\mathrm{Cs}}+\mathrm{BaO}(\text { solid }), & \Delta H=-0.73 \mathrm{eV} . \\
\mathrm{Ba}_{\mathrm{Cs}}+0.25 \mathrm{O}_{2} \rightarrow\left(\mathrm{Ba}_{\mathrm{Cs}}+V_{\mathrm{Cs}}\right)_{\text {complex }}+0.5 \mathrm{Cs}_{2} \mathrm{O} \text { (solid), } & \Delta H=-1.47 \mathrm{eV} . \\
\mathrm{Ba}_{\mathrm{Cs}}+0.25 \mathrm{O}_{2} \rightarrow 0.5\left(2 \mathrm{Ba}_{\mathrm{Cs}}+\mathrm{O}_{\text {int }}\right)_{\mathrm{complex}} & \Delta H=-2.52 \mathrm{eV} . \\
\mathrm{Ba}_{\mathrm{Cs}}+0.25 \mathrm{O}_{2} \rightarrow 0.5\left(\mathrm{Ba}_{\mathrm{Cs}}+V_{\mathrm{Cs}}\right)_{\text {complex }}+0.5 \mathrm{BaO} \text { (solid), } & \Delta H=-3.62 \mathrm{eV} .
\end{array}
$$

Reaction (7c) represents the combination of two $\mathrm{Ba}$ atoms on $\mathrm{Cs}$ sites with an interstitial oxygen atom to form a neutral, self-compensated complex with no precipitation of any other phase. This complex is illustrated in Fig. 36.

The internal oxidation of (7c) is less energetically favorable on a per-Ba basis than the Ba-vacancy complex formation of (7d), which differs from (6) only in that the metallic Ba precipitated in (6) is oxidized to $\mathrm{BaO}$ in (7d). Thus the formation of the Ba-vacancy complex, with expulsion of half the $\mathrm{Ba}$ from the pollucite lattice, is again the most thermodynamically stable outcome. 


\subsubsection{Clustering and segregation}

Our calculations predict a tendency for $\mathrm{Ba}_{\mathrm{Cs}}$ defects to cluster or segregate into Ba-rich regions within a sample of pollucite. For example,

$2 \mathrm{Ba}_{\mathrm{Cs}} \rightarrow\left(2 \mathrm{Ba}_{\mathrm{Cs}}\right)_{\text {complex }} \quad \Delta H=-0.71 \mathrm{eV}, \Delta H / 2=-0.35 \mathrm{eV}$.

$4 \mathrm{Ba}_{\mathrm{Cs}} \rightarrow\left(4 \mathrm{Ba}_{\mathrm{Cs}}\right)_{\text {complex }} \quad \Delta H=-3.42 \mathrm{eV}, \Delta H / 4=-0.85 \mathrm{eV}$.

$8 \mathrm{Ba}_{\mathrm{Cs}} \rightarrow\left(8 \mathrm{Ba}_{\mathrm{Cs}}\right)_{\text {complex }} \quad \Delta H=-8.11 \mathrm{eV}, \Delta H / 8=-1.01 \mathrm{eV}$.

Reactions (8a)-(8c) appear to converge towards a cluster binding energy of about $1 \mathrm{eV}$ per Ba atom. As with individual substitutional $\mathrm{Ba}$ atoms (reaction (6)), these bound complexes also find it energetically favorable to electrically compensate themselves by losing $\mathrm{Ba}$ atoms to the environment, thus adding vacancies to the complex:

$$
\begin{array}{ll}
\left(2 \mathrm{Ba}_{\mathrm{Cs}}\right)_{\text {complex }} \rightarrow\left(\mathrm{Ba}_{\mathrm{Cs}}+V_{\mathrm{Cs}}\right)_{\text {complex }}+\mathrm{Ba}(\text { metal }), & \Delta H=-1.53 \mathrm{eV}, \\
\left(4 \mathrm{Ba}_{\mathrm{Cs}}\right)_{\text {complex }} \rightarrow\left(2 \mathrm{Ba}_{\mathrm{Cs}}+2 V_{\mathrm{Cs}}\right)_{\text {complex }}+2 \mathrm{Ba}(\text { metal }), & \Delta H=-2.14 \mathrm{eV}, \\
\left(8 \mathrm{Ba}_{\mathrm{Cs}}\right)_{\text {complex }} \rightarrow\left(4 \mathrm{Ba}_{\mathrm{Cs}}+4 V_{\mathrm{Cs}}\right)_{\text {complex }}+4 \mathrm{Ba} \text { (metal), } & \Delta H=-4.75 \mathrm{eV} .
\end{array}
$$

Pre-existing Ba-vacancy pairs are also found to tend to cluster together. We have:

$$
\begin{aligned}
& 2\left(\mathrm{Ba}_{\mathrm{Cs}}+V_{\mathrm{Cs}}\right)_{\text {complex }} \rightarrow\left(2 \mathrm{Ba}_{\mathrm{Cs}}+2 V_{\mathrm{Cs}}\right)_{\text {complex }}, \Delta H=-1.08 \mathrm{eV}, \Delta H / 2=-0.54 \mathrm{eV} \\
& 4\left(\mathrm{Ba}_{\mathrm{Cs}}+V_{\mathrm{Cs}}\right)_{\text {complex }} \rightarrow\left(4 \mathrm{Ba}_{\mathrm{Cs}}+4 V_{\mathrm{Cs}}\right)_{\text {complex }}, \Delta H=-3.91 \mathrm{eV}, \Delta H / 4=-0.98 \mathrm{eV} \\
& 8\left(\mathrm{Ba}_{\mathrm{Cs}}+V_{\mathrm{Cs}}\right)_{\text {complex }} \rightarrow\left(8 \mathrm{Ba}_{\mathrm{Cs}}+8 V_{\mathrm{Cs}}\right)_{\text {complex }}, \Delta H=-10.08 \mathrm{eV}, \Delta H / 8=-1.26 \mathrm{eV}
\end{aligned}
$$

The "complex" of eight $\mathrm{Ba}_{\mathrm{Cs}}$ impurities and eight $\mathrm{Cs}$ vacancies in (10c) is actually being modeled by a unit cell with half the Cs replaced by $\mathrm{Ba}$ and the other half missing, as already noted, so we are actually considering a "pollucite" lattice with no cesium. It is reasonable to ask how good is our model of $a$ (vacancy) and $b$ (barium) sites in this limit, given the sites were originally identified for much more dilute defective lattices. Amongst the family of zeolite-like structures related to pollucite, there is one known

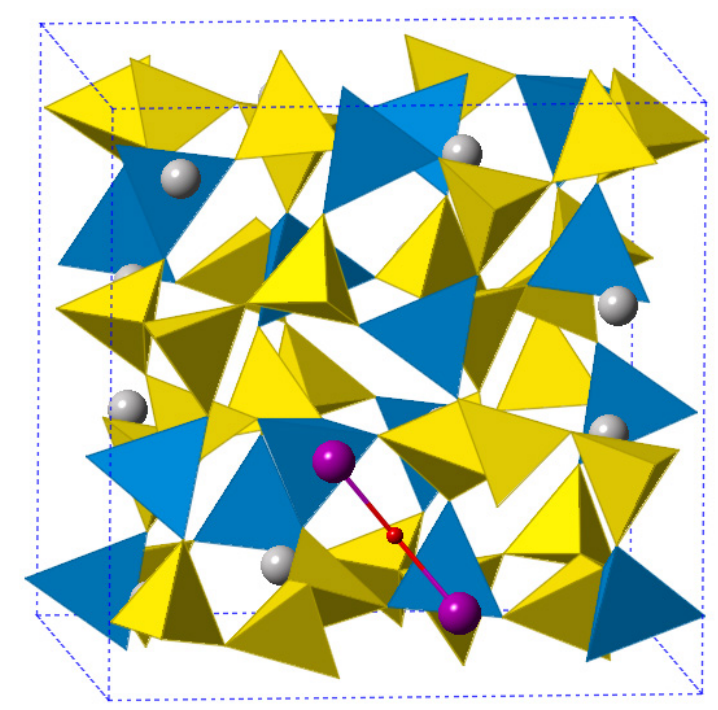

Figure 36. Compensation of $\mathrm{Ba}^{2+}$ by oxygen: $\mathrm{Ba}_{2} \mathrm{O}$ complex. Colors for $\mathrm{Si}, \mathrm{Al}$ and $\mathrm{Cs}$ are as in Fig. 35. Ba is violet, and interstitial oxygen is red. Si is Network oxygen atoms are not shown. The $\mathrm{Ba}$ and $\mathrm{O}$ are covalently bonded, with $\mathrm{Ba}-\mathrm{O}$ distances of 2.33 and $2.26 \AA$.

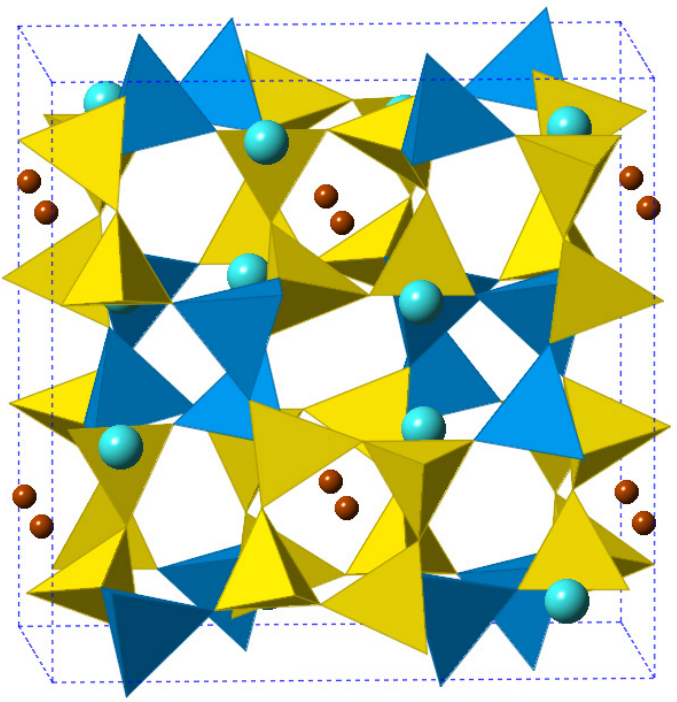

Figure 37. The structure of Waikarite. Colors for $\mathrm{Si}$, $\mathrm{Al}$ and $\mathrm{Cs}$ are as in Fig. 35. The red spheres are the positions for $\mathrm{Ca}^{2+}$ and the light blue spheres are water molecules. In our calculations, $\mathrm{Ba}$ is placed at the $\mathrm{Ca}$ sites and $\mathrm{H}_{2} \mathrm{O}$ is omitted. 
structure that actually has the same composition as our vacancy-compensated Cs-free lattice, namely the structure of wairakite, $\mathrm{Ca}_{0.5} \mathrm{AlSi}_{2} \mathrm{O}_{6}$, but with calcium replaced by barium. The structure of wairakite is shown in Fig. 37.

The reaction converting eight unit cells of pollucite, each with one $\mathrm{Ba}_{\mathrm{Cs}}+V_{\mathrm{Cs}}$ defect complex, to one unit cell of Ba-wairakite (plus seven unit cells of ideal pollucite) is

$8\left(\mathrm{Ba}_{\mathrm{Cs}}+V_{\mathrm{Cs}}\right)_{\text {complex }} \rightarrow\left(8 \mathrm{Ba}_{\mathrm{Cs}}+8 V_{\mathrm{Cs}}\right)_{\text {wairakite }}, \quad \Delta H=-10.50 \mathrm{eV}, \Delta H / 8=-1.31 \mathrm{eV}$.

The energy in (11) in only $0.05 \mathrm{eV}$ lower than in (10c) on a per-Ba basis, suggesting that our defect models based on the pollucite structure cannot be greatly lowered in energy just by simple changes in our (admittedly) somewhat arbitrary modeling choices.

Combining reactions (6) and (11), we find, starting from an ensemble isolated and uncompensated $\mathrm{Ba}_{\mathrm{Cs}}$ defects, that the most exothermic final state (without external oxidation), is given by

$16 \mathrm{Ba}_{\mathrm{Cs}} \rightarrow\left(8 \mathrm{Ba}_{\mathrm{Cs}}+8 V_{\mathrm{Cs}}\right)_{\text {wairakite }}+8 \mathrm{Ba}$ (metal), $\Delta H=-28.40 \mathrm{eV}, \Delta H / 16=-1.78 \mathrm{eV}$.

\subsection{Alternate Chemical Formulation: Fe-containing Pollucite Structures}

In conjunction with results /efforts at Sandia National Laboratory for Fe-containing pollucite samples, we performed exploratory calculations of Fe-substituted pollucite. Fe was substituted for $\mathrm{Al}$ in the pollucite network. While initial results indicate that the variable charge state of Fe ions may serve to compensate the $\mathrm{Ba}^{2+}$ ions, analysis of the results is still in progress.

\section{CONCLUSIONS}

We find that the underlying silicate backbone structure of the pollucite network has ordering that suggests preferred ordering of the Al distribution. Variation in the aluminum distribution has only a minor effect on the total system energy, so many aluminum distributions are nearly degenerate, and driving force for ordering in the Al sublattice may be expected to be small.

With the decay of $\mathrm{Cs}$ to $\mathrm{Ba}$, we find that the removal (or escape) of Cs is energetically unfavorable. The lowest equilibrium energy is achieved by precipitating half the $\mathrm{Ba}$ (as metal or $\mathrm{BaO}$, if oxygen is supplied by environment) so the remaining $\mathrm{Ba}(\mathrm{Cs})$ is compensated by $\mathrm{Cs}$ vacancies. This means that as the waste form decays, remaining Cs should stay trapped. However, information about ion mobilities is still needed.

Finally, we find that at equilibrium, $\mathrm{Ba}$ and vacancies tend to segregate into Ba-rich regions. This is consistent with the segregation of $\mathrm{Ba}$ that is seen in the analysis of the Ba-doped pollucite sample provided by Sandia Laboratory. This raises questions about the effects of Ba precipitation in the decaying waste form.

\section{FUTURE DIRECTIONS AND CONTINUED EFFORT}

In order to make further progress toward a validated model for pollucite waste forms, we have additional calculations planned.

(1) As pollucite undergoes significant damage and may be amorphized (as many silicates may be under irradiation), we will include an investigation of defects in the aluminosilicate structure.

(2) To correlate directly with the implantation experiments, we will include fluorine-based defects.

(3) We will determination ion mobilities under different Ba substitution conditions. 


\section{ACKNOWLEDGMENT}

This work was supported by Nuclear Energy Research \& Development, U.S. Department of Energy under Contract DE-AC05-76RL01830. The research was performed using EMSL, a national scientific user facility sponsored by the Department of Energy's Office of Biological and Environmental Research and located at Pacific Northwest National Laboratory.

\section{References}

Anchell, JL, et al. 1994. "An Ab Initio Periodic Hartree-Fock Study of Group Ia Cations in Ana-Type Zeolites." J. Phys. Chem. 98:4463.

Blöchl, PE. 1994. "Projector Augmented-Wave Method." Physical Review B 50:17953.

Forsberg, CW. 2000. " Rethinking High-Level Waste Disposal: Separate Disposal of High-Heat Radionuclides ${ }^{90} \mathrm{Sr}$ and ${ }^{137}$ Cs." Nucl. Technol. 131:252.

Fortner, JA, et al. 1999. "Determination of Transmutation Effects in Crystalline Waste Forms." Final Report to the US Department of Energy on project number 55382.

Garino, TJ, et al. 2009. "The Crystallization of Ba-Substituted CsTiSi ${ }_{2} \mathrm{O}_{6.5}$ Pollucite Using $\mathrm{CsTiSi}_{2} \mathrm{O}_{6.5}$ Seed Crystals." J. Am. Ceram. Soc. 92:2144.

Hess, N, et al. 2000. "Beta Radiation Effects in ${ }^{137}$ Cs Substituted Pollucite." J. Nucl. Mater. 281:22.

Holand, W, and GH Beall. 2012. Glass-Ceramic Technology, Second Edition. The American Ceramic Society, John Wiley and Sons, Inc., Hoboken, New Jersey.

Jaffe, J, RV Ginhoven, and W Jiang. 2012. "Interstitial and Substitutional Zirconium in $\mathrm{SrTiO}_{3}$." Comp. Mater. Sci. 53:153.

Jiang, W, RV Ginhoven, and D Strachan. 2011, Chemical and Charge Imbalance Induced by Radionuclide Decay: Effects on Waste Form Structure, 2011 FCRD WAST-2011-000070. Report, Pacific Northwest National Laboratory, Pacific Northwest National Laboratory.

Jiang, W, et al. 2012a. "Superlattice Structure and Precipitates in $\mathrm{O}^{+}$and $\mathrm{Zr}^{+}$Ion Co-Implanted $\mathrm{SrTiO}_{3}$ : A Model Waste Form for ${ }^{90}$ Sr." J. Phys. Chem. C 116:16709.

Jiang, W, ME Bowden, Z Zhu, P Jozwik, J Jagielski, and A Stonert. 2012b. "Defects and Minor Phases in $\mathrm{O}^{+}$and $\mathrm{Zr}^{+}$Ion Co-Implanted $\mathrm{SrTiO}_{3}$." Industrial \& Engineering Chemistry Research 51:621.

Kaminski, MD, et al. 2009. "Physical Properties of an Alumino-Silicate Waste Form for Cesium and Strontium." J. Nucl. Mater. 392:510.

Kobayashi, H, et al. 2006. "Phase Transition and Lattice Thermal Expansion of Cs-Deficient Pollucite, $\mathrm{Cs}_{(1-\mathrm{X})} \mathrm{Al}_{(1-\mathrm{X})} \mathrm{Si}_{(2+\mathrm{X})} \mathrm{O}_{6}(\mathrm{X} \leq 0.25)$, Compounds." J. Am. Ceram. Soc. 89:3157-61.

Kobayashi, H, I Yanase, and T Mitamura. 1997. "A New Model for the Pollucite Thermal Expansion Mechanism." J. Am. Ceram. Soc. 80:2161.

Kresse, G, and J Furthmüller. 1996. "Efficiency of Ab-Initio Total Energy Calculations for Metals and Semiconductors Using a Plane-Wave Basis Set." Comput. Mater. Sci. 6:15.

Lide, DR. 2003. Handbook of Chemistry and Physics. CRC Press, Boca Raton, FL.

MacLaren, I, J Cirre, and CB Ponton. 1999. "Hydrothermal Synthesis of Pollucite (Csalsi $\left.{ }_{2} \mathrm{O}_{6}\right)$ Powders." J. Am. Ceram. Soc. 82:3242. 
Mimura, H, M Shibata, and K Akiba. 1990. "Surface Alteration of Pollucite under Hydrothermal Conditions." J. Nucl. Sci. Technol. 27:835.

Monkhorst, HJ, and JD Pack. 1976. "Special Points for Brillonin-Zone Integrations*." Phys.Rev. B 13:5188.

Nenoff, TM, T Garino, and D Rademacher. 2011, The Decay Effects on the Stability of Fission Product Waste Forms. Report, Sandia National Laboratories, Albuquerque, NM.

Ogorodova, LP, et al. 2003. "Thermochemical Study of Natural Pollucite." Thermochimica Acta 403:251.

Palmer, DC, et al. 1997. Am. Mineral. 82:16.

Perdew, JP, K Burke, and M Ernzerhof. 1996. "Generalized Gradient Approximation Made Simple." Physical Review Letters 77:3865.

Richerson, DW, and FA Hummel. 1972. "Synthesis and Thermal Examination of Polycrystalline Cesium Materials." J. Am. Ceram. Soc. 55:269.

S. Komameni, and WB White. 1981. "Stability of Pollucite in Hydrothermal Fluids." Sci. Basis Nucl. Waste Manage. 3:387.

Sanchez-Valle, C, C-H Chio, and GD Gatta. 2010. "Single-Crystal Elastic Properties of (Cs,Na)Alsi ${ }_{2} \mathrm{O}_{6} \cdot \mathrm{H}_{2} \mathrm{O}$ Pollucite: A Zeolite with Potential Use for Long-Term Storage of Cs Radioisotopes." J. Appl. Phys. 108:093509.

Strachan, DM, and Schultz, Wallace W. 1979. "Characterization of Pollucite as a Material for Long-Term Storage of Cesium-137." American Ceramic Society Bulliten 58:865.

Strachan, DM, et al. 1997, Determination of Transmutation Effects in Crystalline Waste Forms, Annual Report for FY 1997. Report.

Thevuthasan, S, CHF Peden, MH Engelhard, DR Baer, GS Herman, W Jiang, Y Liang, and WJ Weber. 1999. " The Ion Beam Materials Analysis Laboratory at the Environmental Molecular Sciences Laboratory." Nuclear Instruments and Methods in Physics Research A 420:81.

Yanagisawa, K, M Nishioka, and N Yamasaki. 1987. "Immobilization of Cesium into Pollucite Structure by Hydrothermal Hot-Pressing." J. Nucl. Sci. Technol. 24:51.

Yanase, I, S Tamai, and H Kobayashi. 2003. "Sintering of Pollucite Using Amorphous Powder and Its Low Thermal Expansion Property." J. Ceram. Soc. Jpn. 111:533.

Ziegler, J, JP Biersack, and U Littmark. 1985. The Stopping and Range of Ions in Solids. Pergamon, New York. 